
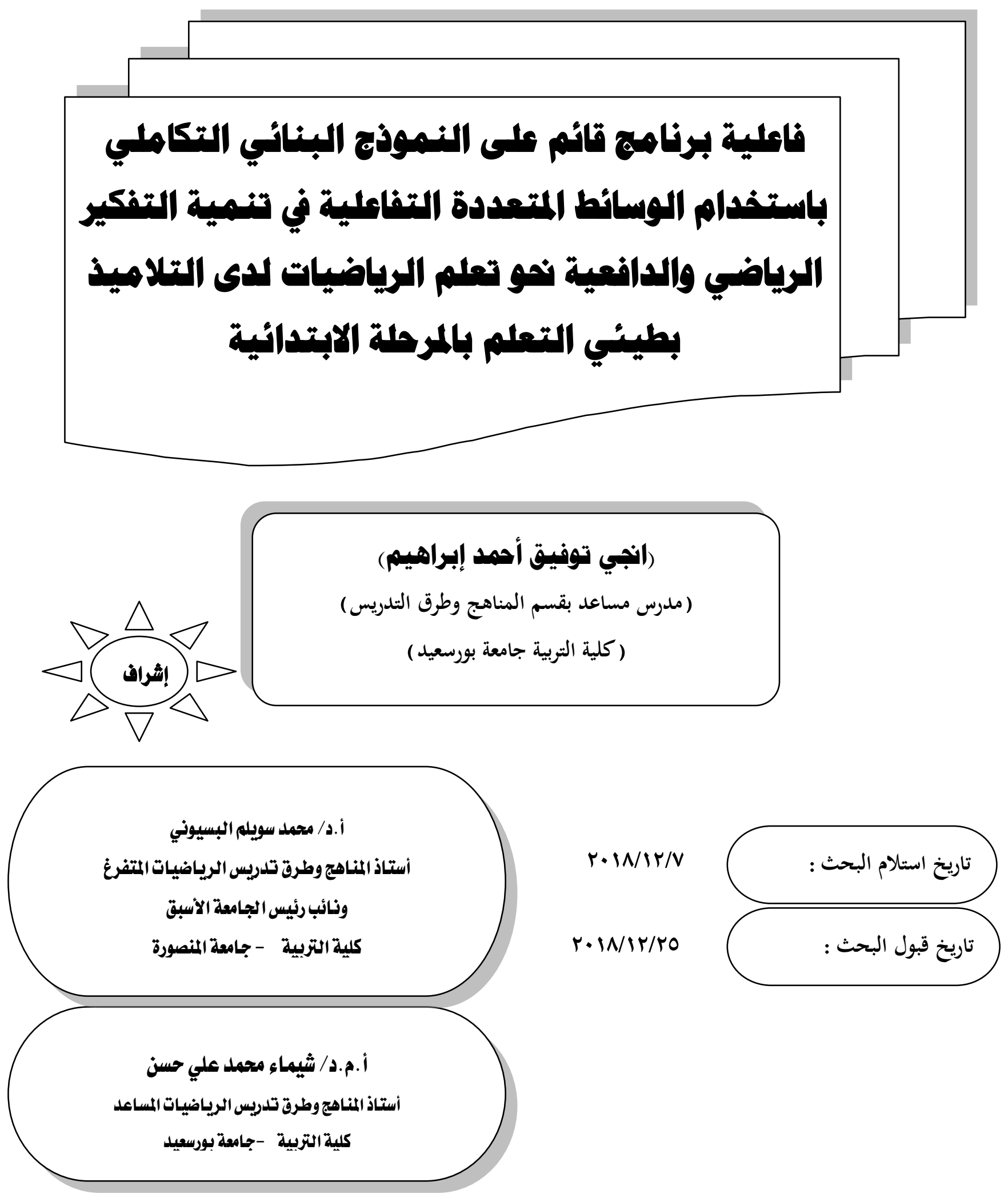


\section{| ال|فص}

هدف البحث إلى الكشف عن فاعلية النموذج البنائي التكاملي باستخدام الوسائط المتعددة التفاعلية في تنمية التفكير الرياضي والدافعية نحو تعم الرياضيات لاى التلاميذ بطيئي التعلم بالمرحلة الابتدائية وتكونت عينة البحث من مجموعتين أحدهما تجريبية بلغ عددها (Y^) تلميذ وتلميذة والأخرى ضابطة بلغ عددها (Y^) تلميذ وتلميذة من تلاميذ الصف الخامس الابتائي بطيئى التعلم بمحافظة بورسعيد ،ولتحقيق هدف البحث أعدت الباحثة مجموعة من المواد التعليمية تمثلت في قائمة بمهارات التفكير الرياضي فى الرياضيات، ويرنامج الوسائط المتعددة التفاعلية، كما تم إعداد أدوات البحث والتي تمثلت في اختبار التفكير الرياضي ،ومقياس للافعية نحو مادة الرياضيات وأشارت نتائج البحث إلى فاعلية النموذج البنائي التكاملي باستخدام الوسائط المتعددة التفاعلية في تنمية التفكير الرياضي والدافعية نحو تعلم الرياضيات لاى التلاميذ بطيئي التعلم بالمرحلة الابتائية. الاكمات الافتاحية النموذج البنائي التكاملي ، الوسائط المتعددة التفاعلية ، التفكير الرياضي، الدافعية نحو تعلم الرياضيات ، التلاميذ بطيئي التعلم

\section{ABS'TRAC'}

The research aims to reveal the effectiveness of the integrated constructivism model using the interactive media in the development of mathematical thinking and motivation towards learning mathematics in the slow learning pupils in the primary stage. The research group consisted of two groups, one of them experimental (28) students and the other officer (28) students and pupils of the fifth grade primary in Port Said Governorate, to achieve the objective of the research, the researcher prepared a set of educational materials that were included in the list of mathematical thinking skills in mathematics, A program using the Integrated constructivism model based on interactive multimedia, Test in mathematical thinking skills, and motivation towards learning mathematics scale. The results of the research indicated the effectiveness of integrated constructivism model using interactive media in the development of mathematical thinking and motivation towards learning mathematics among students with slow learning in the primary stage.

\section{KIYWORIDS:}

Integrated constructivism model, interactive media, mathematical thinking, motivation towards learning mathematics, slow learning 


\section{هقدمة مقة}

يتسم العصر الحالي بالتغيرات السريعة والمتجددة التي نثأت من تقدم العلم وتطبيقاته في جميع مجالات الحياه الأمر الأي يحتم على الفرد امتلاك مقومات الحياه العلمية والعملية ويضع أمام التريويين تحديات صعبة ومنها إعداد كوادر بشرية مؤهلة للتكيف مع المتغيرات السريعة ومواكبة التطورات المتلاحقة ويذلك تسنطيع مواجهة تعديات المستقبل .

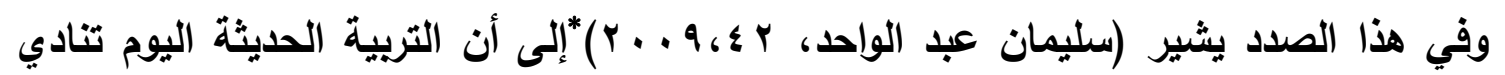

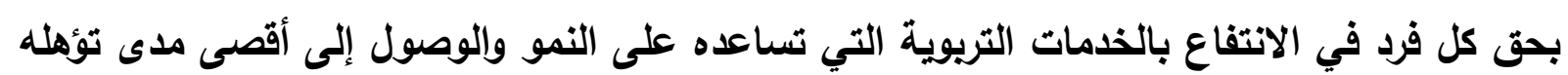

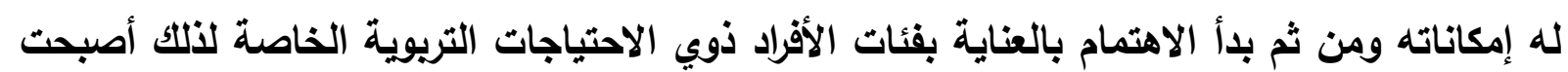

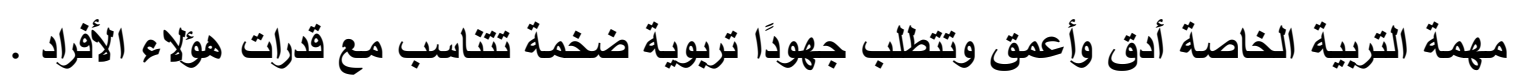

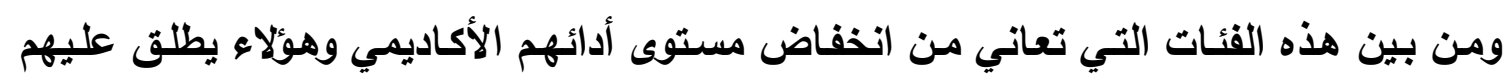

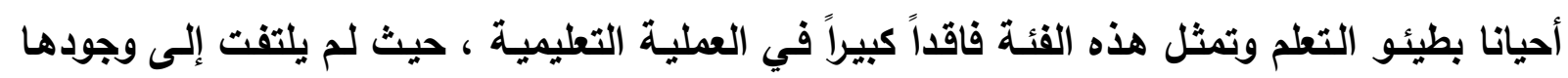

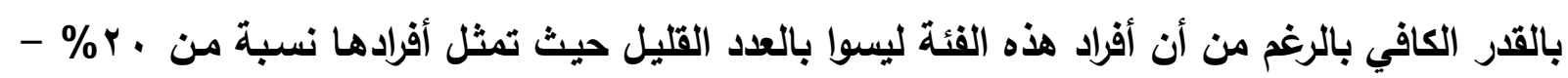

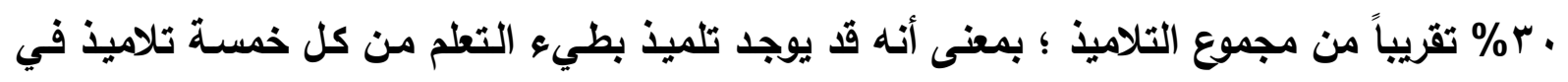

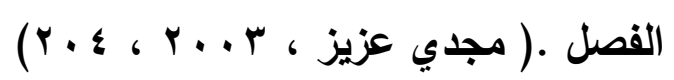

وتعد تنمية مهارات التفكير الرياضي لدى جميع التلاميذ بالمراحل المختلفة من الأهداف الأساسية

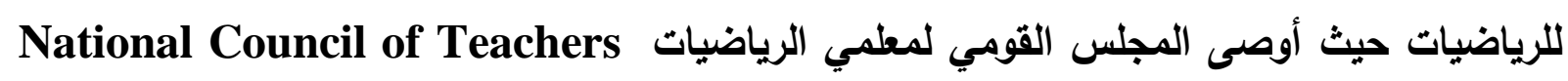
، بأهمية إثارة فكر المتعلم وتنمية قدراته التفكيرية التبات ولهذا فإنه من الضروري العمل على توفير كافة الفرص التريوية التي تساعد على تنمية التفكير

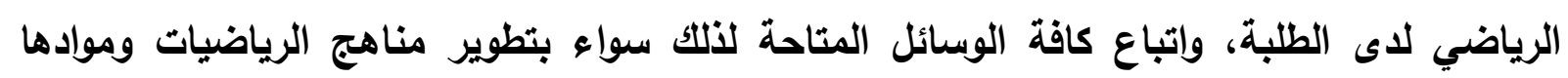

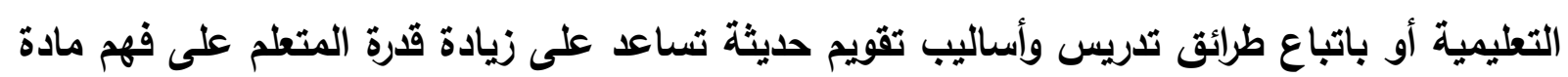

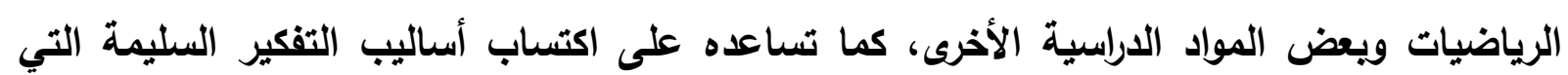

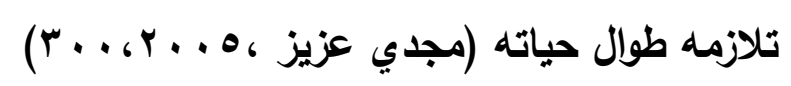

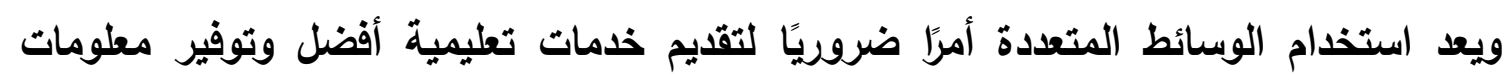

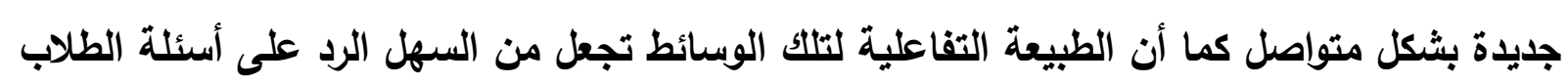

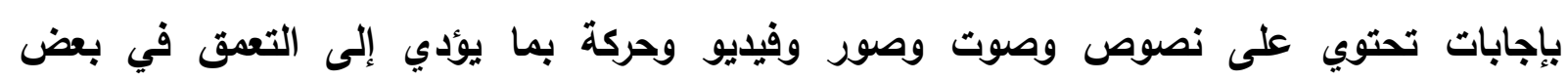

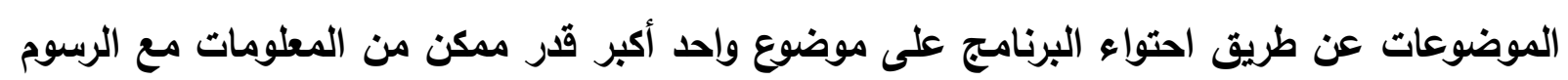

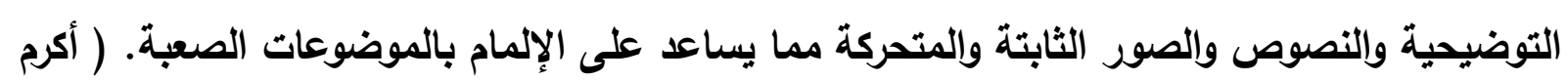

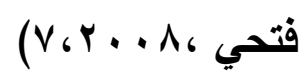


وتعتبر التفاعلية من أهم العناصر في تصميم محتوى برامج الوسائط المتعددة وإن كانت في لئي

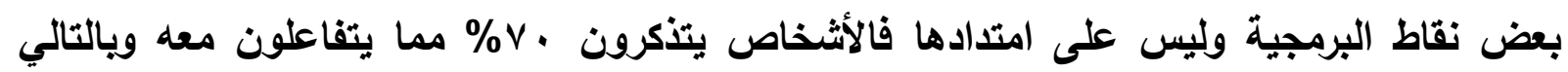

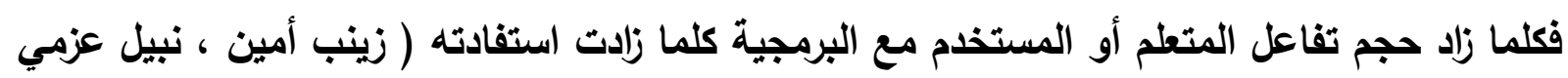

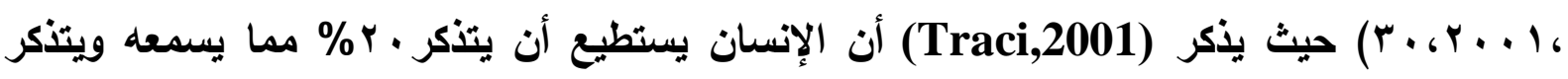

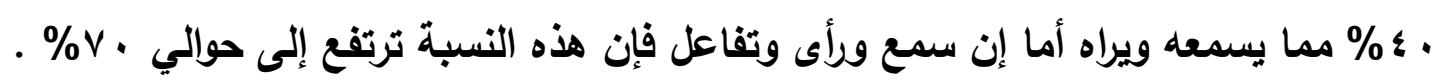

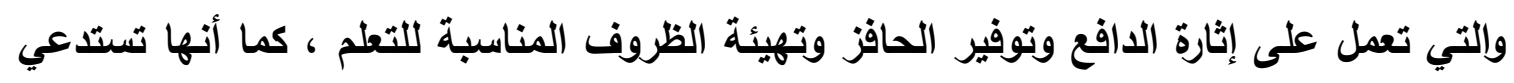
الخبرات السابقة وتمد المتعلمين بخبرات تساهم في تنشيط استجابة المتعلم وقيامه بدور ايجابي وإكسابه مهارات متتوعة وتعديل اتجاهه وتتمية ميوله .

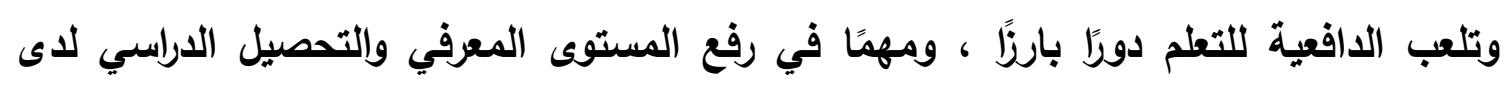

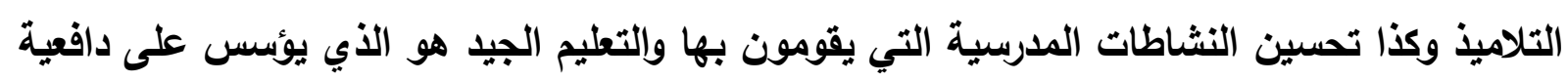

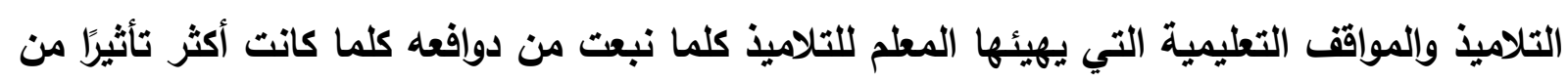

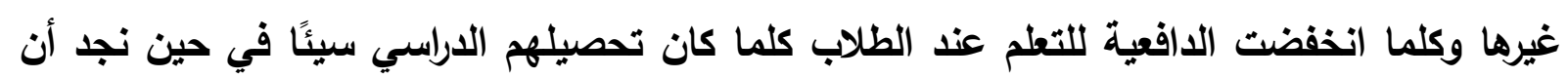
الطلاب الذين لايهه دافع للتعلم وللتحصيل الدراسي يعملون بجدية أكبر من غيرهم ويحققون نجاحات الطيات

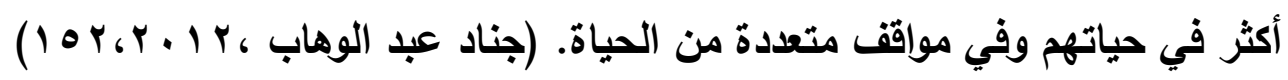

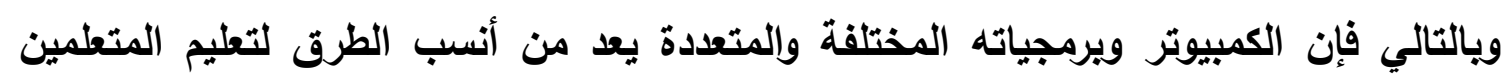

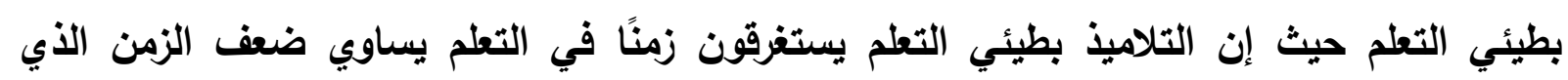

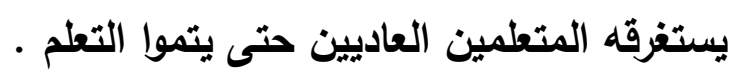

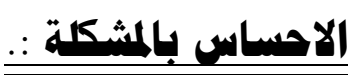

بالإضافة إلى الدافعية التي تولدت لإى الباحثة من تجريب استخدام الوسائط المتعددة التفاعلية من

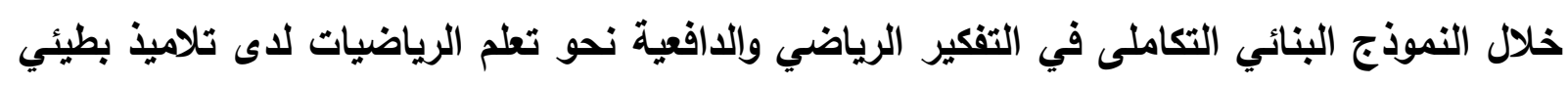

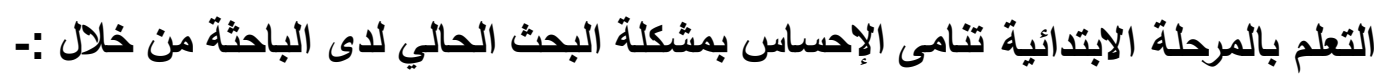

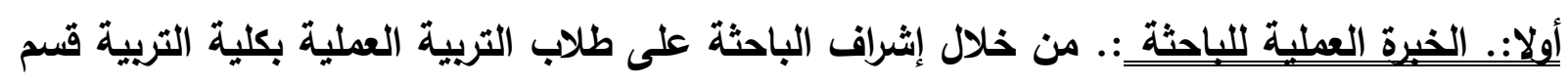
الرياضيات شعبة التعليم الابتدائي لاحظت إهمال المطمين لفئة من التلاميذ داخل الفئل الفصل ولئل وعدام

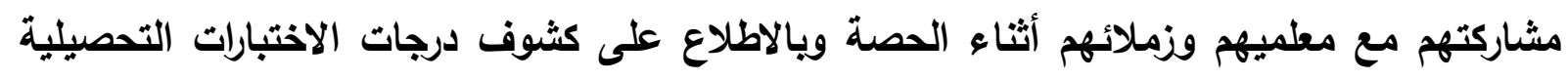

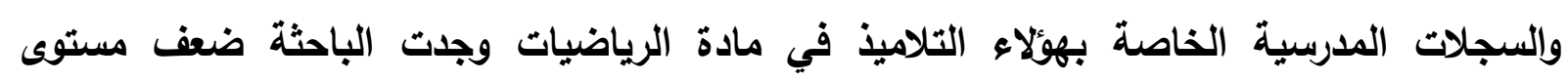
تحصيلهم ثانبا:. الاراسة الاستطلاعبة للباحثة قامت الباحثة بعمل دراسة استطلاعية تمثلت في تطبيق استبانه مفتوحة على (·× معلم ومعلمة من معلمي الرياضيات القائمين على التدريس بالمرحلة الابتدائية

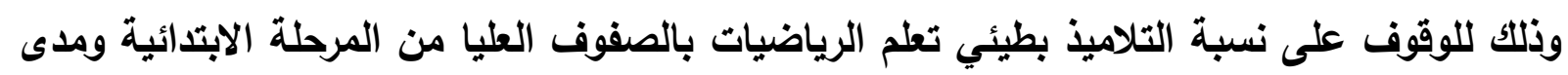


وعى معلمي الرياضيات بالمرحلة الابتدائية بهذه الفئة داخل فصولهم وكيفية التعامل معها ومدى لإئي

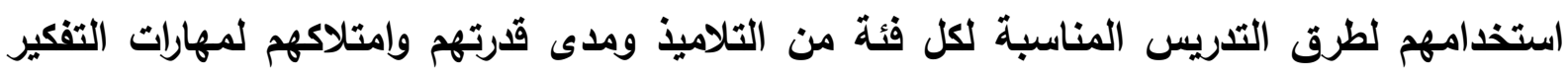
بصفة عامة ومهارات التفكير الرياضي بصفة خاصة وتوصلت الباحثة إلى:

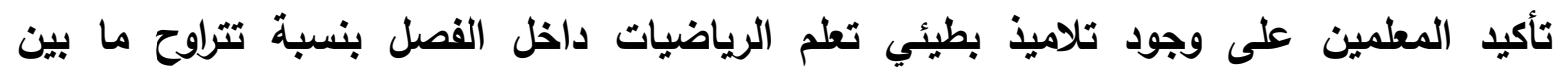

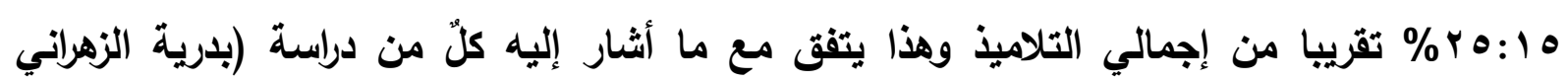

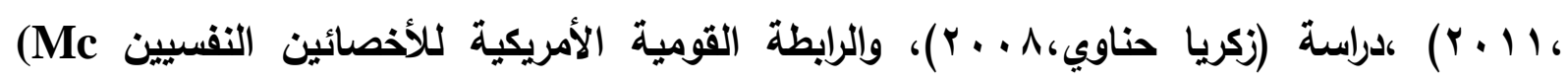

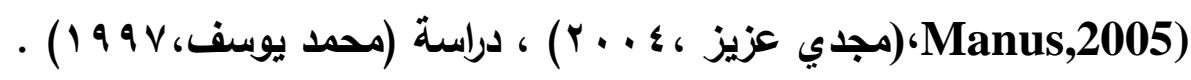

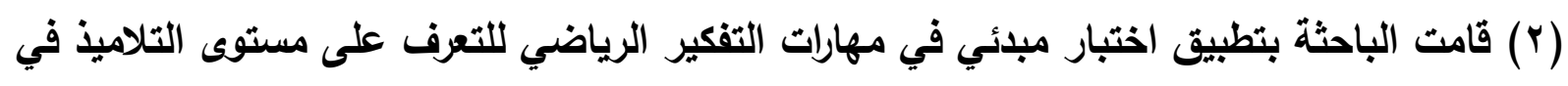

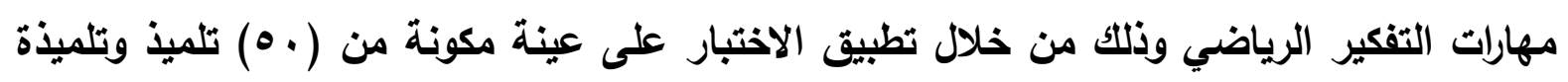

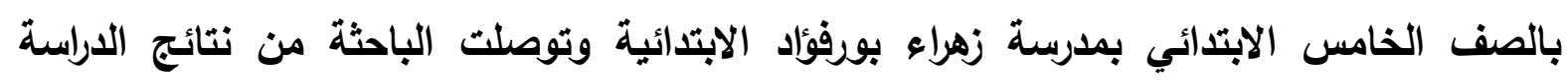

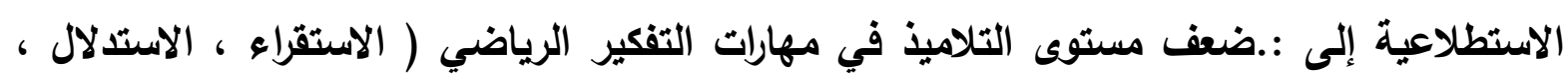

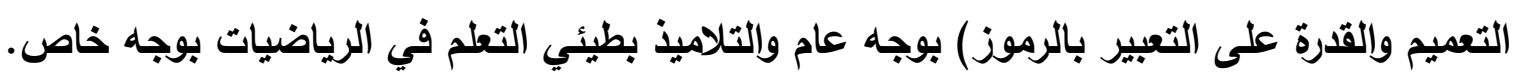

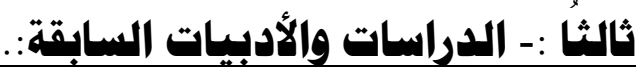

باستقراء الأدبيات والداراسات السابقة التي اهتمت بدراسة بطيئي تعلم الرياضيات أكلت معظمها على:-

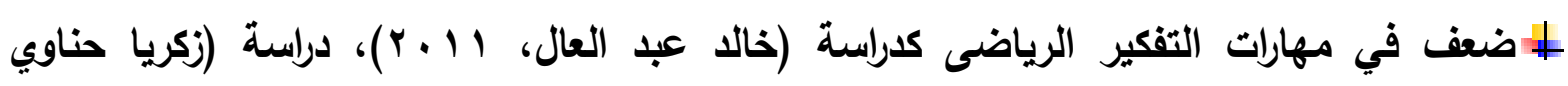

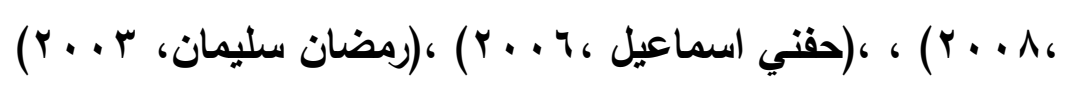

| نقص الدافعية نحو التطلم بصفة عامة والرياضيات بصفة خاصة كدراسة ( فاطمة أبو حديد

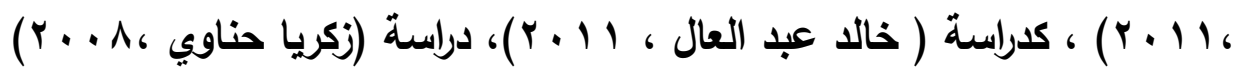

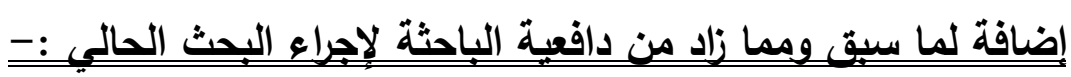

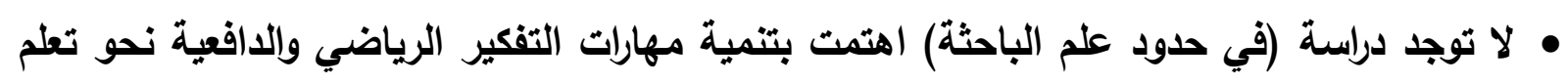
الرياضيات لاى تلاميذ المرحلة الابتائية بطيئي تطلم الرياضيات في ضوء برنامج قائم على النموذج البنائي التكاملي باستخدام الوسائط المتعددة التفاعلية . أسئلة البحث :.تحددت مشكلة البحث في السؤال الرئيس التالي :"ما فاعلية التذريس النموذج البنائي التكاملي باستخذام الوسائط المتعددة التفاعلية في تنمية التفكير

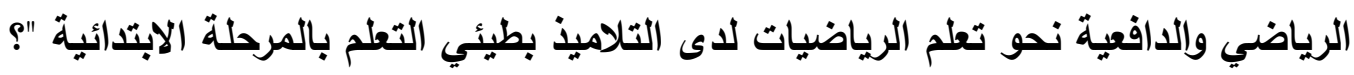

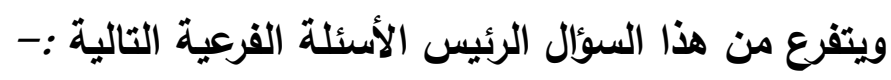
ا.ما مهارات التفكير الرياضي اللازم تنميتها لاى التلاميذ بطيئي التعلم بالمرحلة الابتدائية ؟ 
r.ما صورة النموذج البنائي التكاملي باستخدام الوسائط المتعددة التفاعلية في تنمية التفكير الرياضي

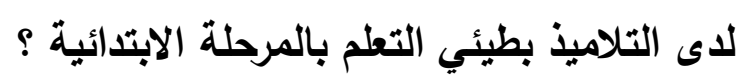

r. ما فاعلية التدريس النموذج البنائي التكاملي باستخدام الوسائط المتعددة التفاعلية في تنمية الدافعية نحو تعلم الرياضيات لاى التلاميذ بطيئي التعلم بالمرحلة الابتدائية ؟

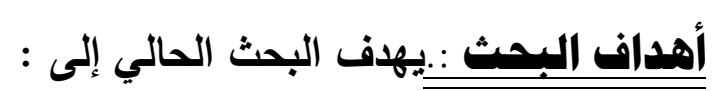

ا.تقديم برنامج قائم على النموذج البنائي التكاملي باستخدام الوسائط المتعددة التفاعلية لتنمية التفكير الرياضي والدافعية نحو تعلم الرياضيات لدى التلاميذ بطيئي التعلم بالمرحلة الابتدائية. r. التحقق مـن فاعليـة البرنـامج في تنميـة التفكير الرياضـي لــى التلاميذ بطيئسي التعلم بالمرحلـة الابتدائية.

r.التحقق من فاعلية البرنـامج في تنمية الدافعيـة نحو تعلم الرياضيات لدى التلاميذ بطيئي التعلم بالمرحلة الابتدائية.

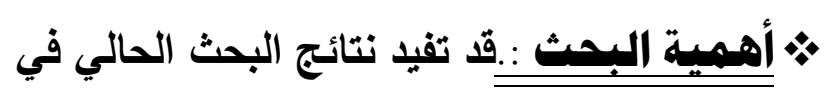

- توجيه نظر مخططى ومطوري المناهج إلى ضرورة استخذام التكنولوجيا في تدريس الرياضيات لذوي الاحتياجات الخاصة وخاصة فئة بطيئي التعلم بثكل يساهم في رفع مستوى تحصيلهم وتفكيرهم . - تمكين المعلمين والموجهين من استخدام استراتيجيات تعلم حديثة تنادي بضرورة الاهتمام بتدريب التلاميذ ذوي الاحتياجات الخاصة بصفة عامة والتلاميذ بطيئي التعلم بصفة خاصة على التفكير بلاًا

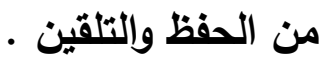
- مساعدة التلاميذ بطيئي التعلم إلى النمو لأقصسي ما تسمح بـه إمكاناتهم ومسـاعدتهم على تنميـة مهارات التفكير الرياضي وفقا لسرعتهم الخاصة . - تقديم توصيات ومقترحات بحثية جديده للباحثين تفتح المجال أمامهم لبحوث ودراسات أخرى.

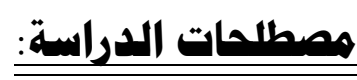

The Interactive Multimedia الوسائط المتعدة التفاعلية

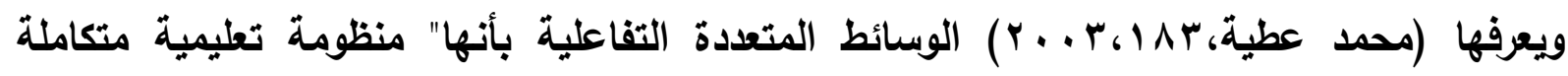
تثتمل على عدة مكونات من الوسائط المتعددة " نصوص مكتوية، صوت مسموع، رسوم ثابتة ومتحركة، صور ثابتة ومتحركة متكاملة مع بعضها البعض وتعمل بطائل بطريقة منظومية ومتفاعلة كوحدة 
وظيفية واحدة تمكن المتعلم من التحكم فيها والتعامل معها من خلال جهاز الحاسب الآلي أو أى الى

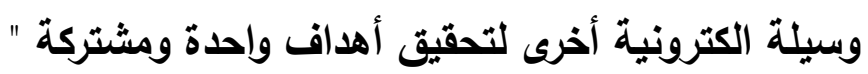

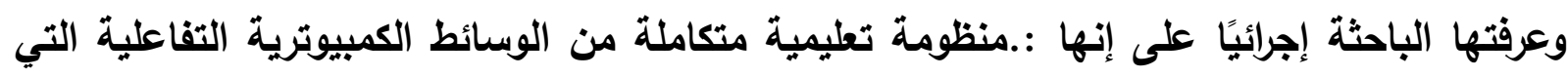

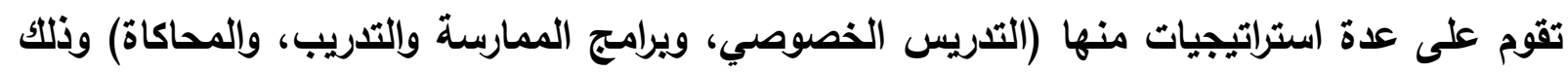

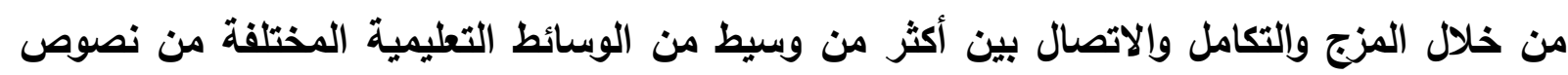

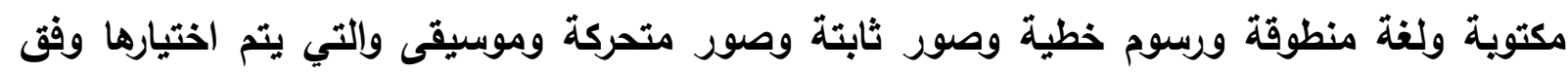

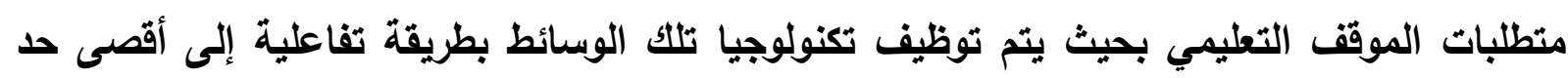

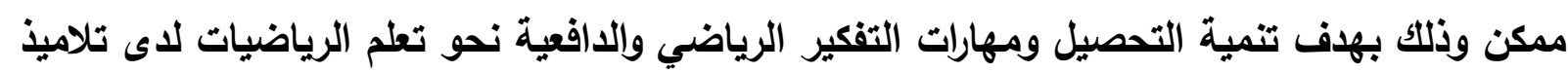

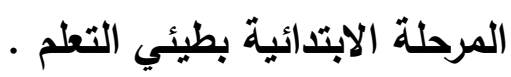
r. التفكير الرياضي Mathematical thinking يعرف التفكير الرياضي بأنه قرة المتعلم على

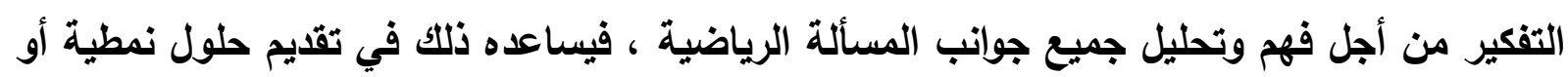

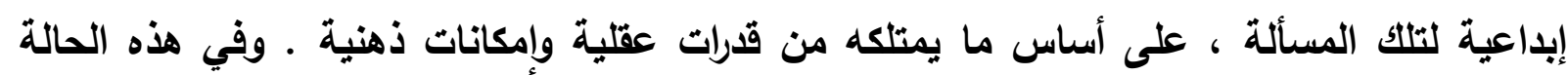

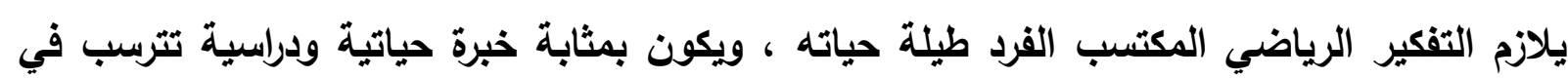

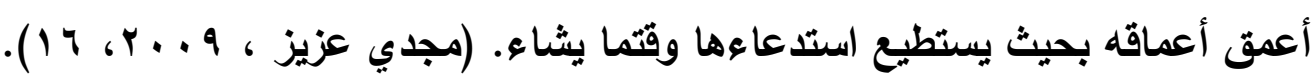

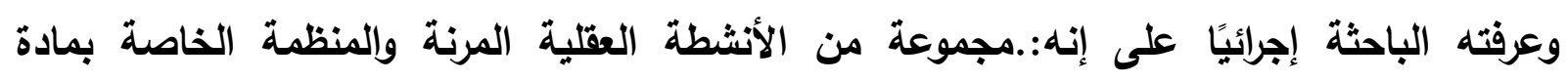

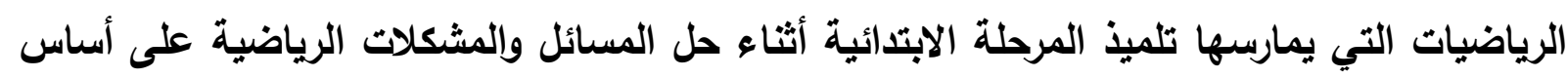

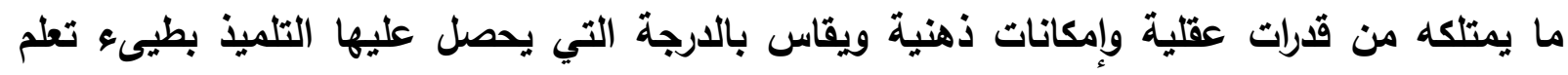

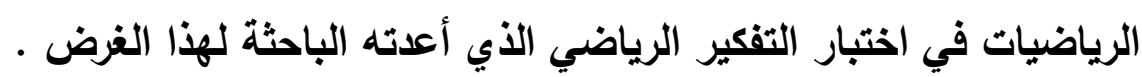

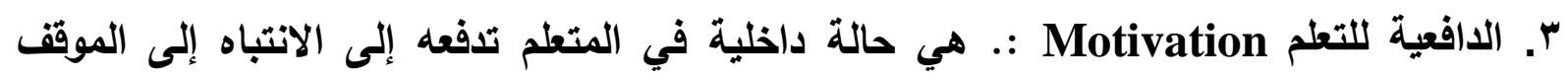

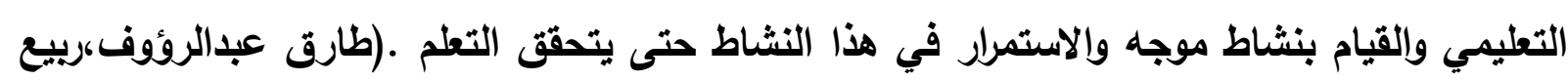

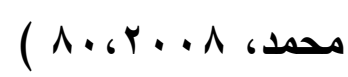
وتعرف إجرائيًا في البحث الحالي"'بأنها حالة داخلية لدى المتعلم تحرك أفكاره ووعيه تدفعه إلى الاهتمام

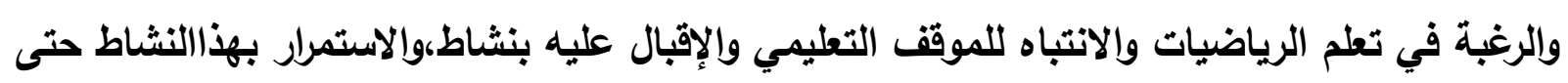
يتحقق التعلم كهذف للمتعلم وتقاس في هذا البحث من خلال الدرجة التي يحصل عليها التلميذ بطيئ

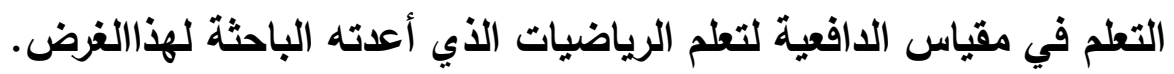

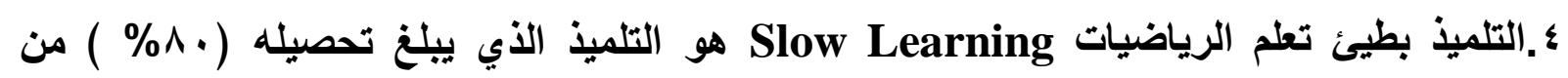
مستوى أقرانه في نفس الفصل الدراسي في الاختبارات التحصيلية في الرياضيات كما أن نسبة ذكائه

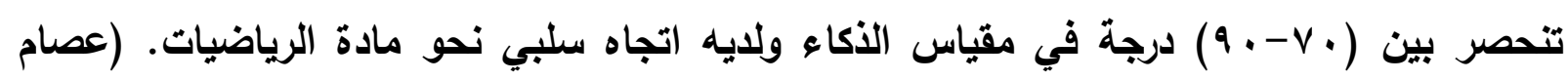

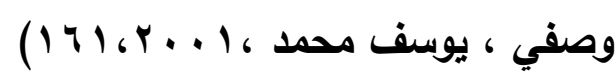




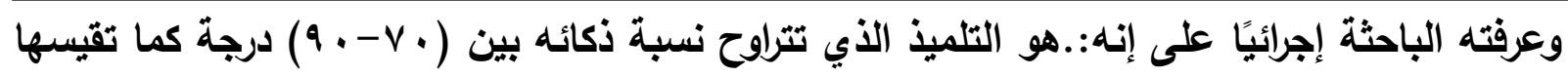

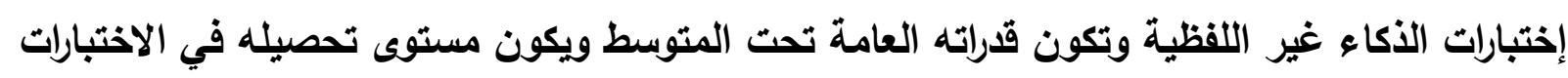

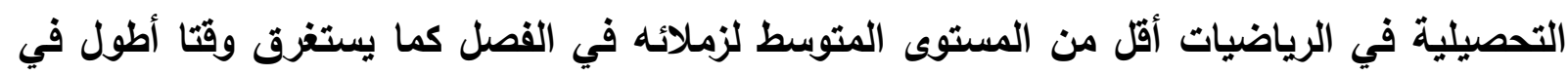
التطلم مقارنة بأقرانه في الفصل فيافيات

\section{الاطار النظري والدراسات السابقة}

المهور الأول : نهوذج التعلم البنائي التكاهيلي

نهوذج التعلم البنائي التكاهلي

أثشار الأدب التربوي والنفسي إن يتكون نموذج التعلم البنائي التكاملي من ثلاث مراحل متتالية على كل مرحلة مرتبطة ارتباطاً بالمرحلة التي تليها ويمكن تقليم هذه المرحلة على النحو التالي: ( Banet\&

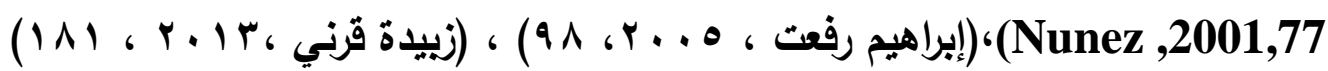

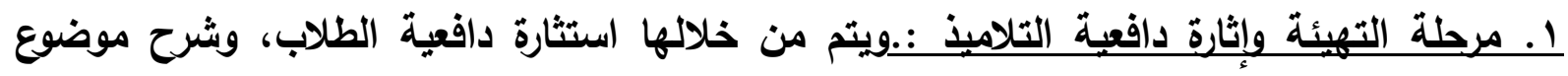

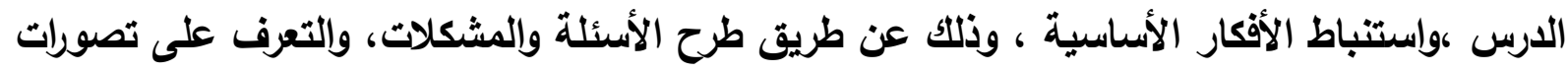

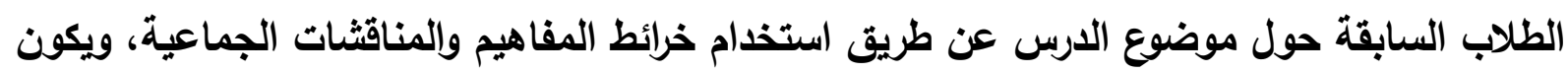

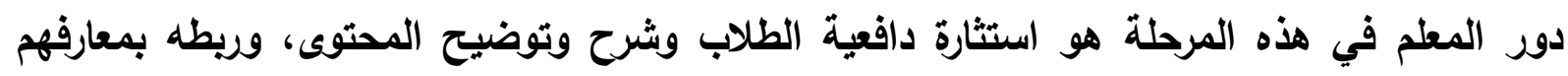

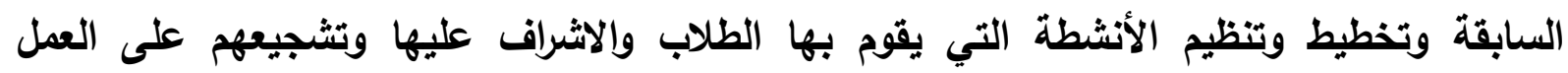

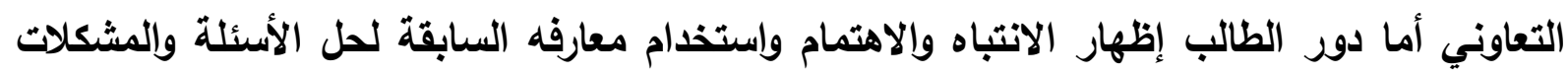

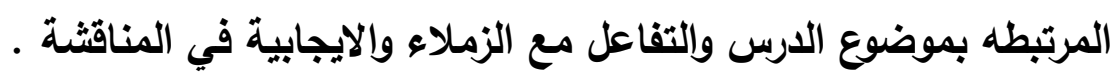

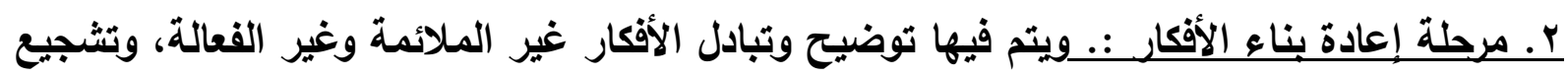

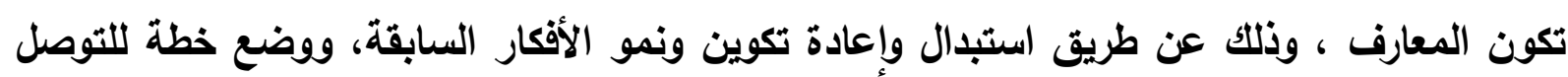

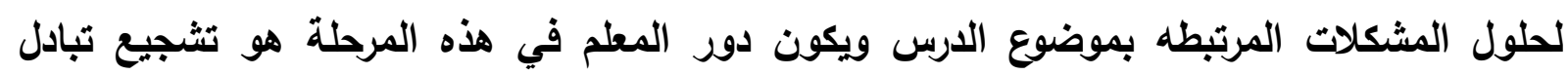

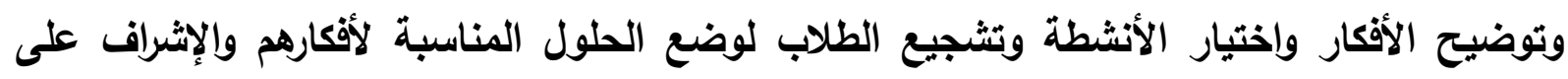

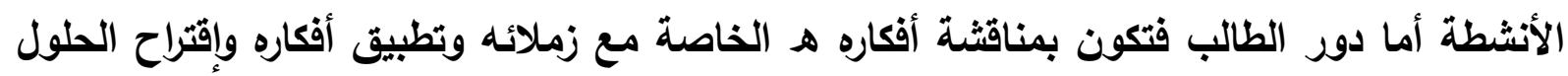
للمشكلات والمشاركة الايجابية في الأنشطة وتوجيهها نحو إعادة بناء أفكاره.

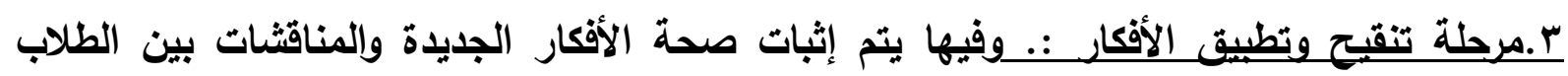
للتأكد من حدوث تغيير في أفكارهم عن الأفكار السابقة ويكون دور المعلم هو اختيار التصورات والمشكلات الحياتية اليومية وربطها بالأفكار الجديدة ، ومساعدة الطلاب على مقار الألىارنة الأفكار السابقة

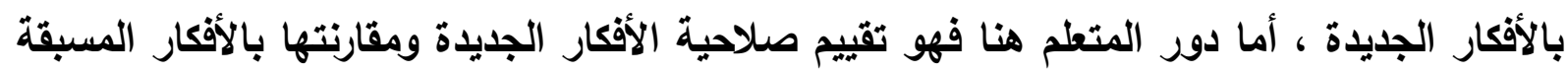

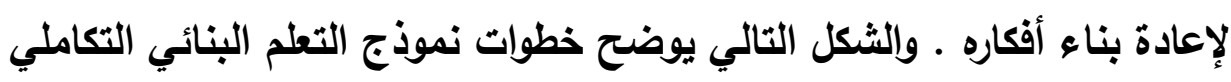


شكل ( ) خطوات نموذج التعلم البنائي التكاملي

\section{خ مميزات نموذج التعلم البنائي التكاملي}

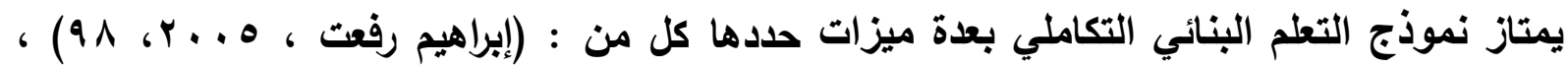

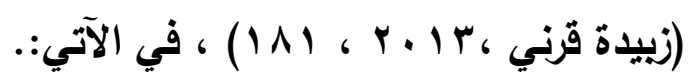

ا. أحد النماذج الهامة في تدريس العلوم والقائمة على النظرية البنائية . r. يهتم بالتعرف على الأفكار المسبقة لاى التلاميذ .

r.يركز على ايجابية المتعلم أثناء عملية التعلم ويهتم بريط المعلومات والمعارف التي يواجهها الطالب بحياته اليومية وذلك بعد إعادة بنائها في البنية المعرفية لها

\section{المور الثاني : الوسائط المتعددة التفاعلية}

1) ماهية الوسائط المتعددة التفاعلية

لقد تعددت التعريفات التي تتاولت مفهوم الوسائط المتعددة التفاعلية ، نظرًا لتعدد إمكاناتها وانتثارها في مختلف نواحي الحياة، وأصبح مفهوم الوسائط المتعددة من أكثر المفاهيم ارتباطًا بحياتنا اليومية، وخاصة في مجال التعليم ويالأخص مع ظهور عملية وانية تفريد التعليم .

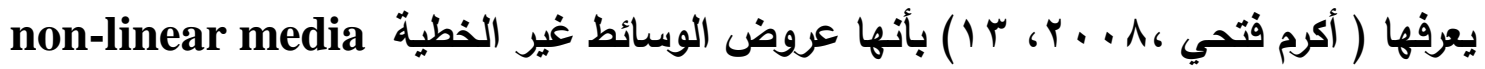
التي تعتمد على الكمبيوتر وهي عروض تستخلم جميع وسائط الاتصال المستخدمة في الوسائط

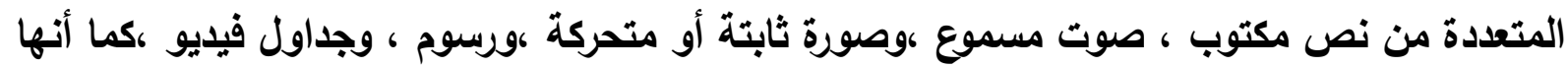
تمكن المتعلم من التحكم المباشر في تتابع المعلومات حيث تسمح له بالتحكم في اختيار وعرض

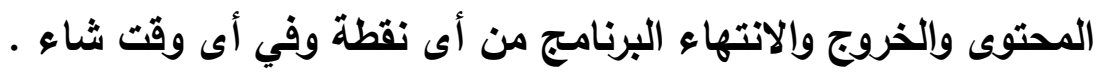
وتعرفها (Andrado؛ Mercado\& Reynoso, 2008) بأنها برامج كمبيوترية تمزج بين

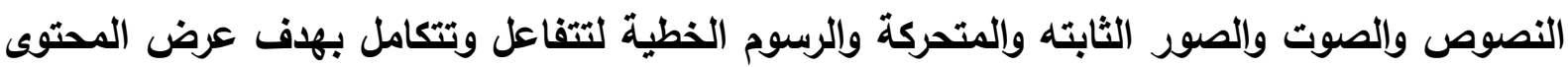
التعليمي ليتفاعل معه المتعلم داخل موقف التعليم الفردي والجماعي وذلك لإحداث التعلم المنشود.

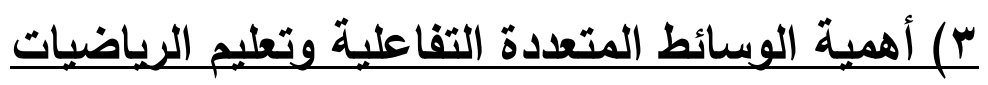

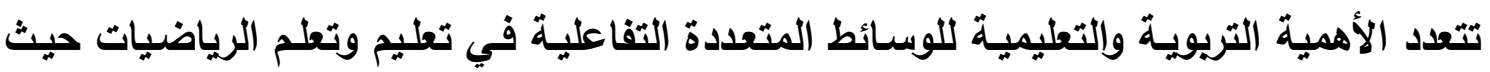

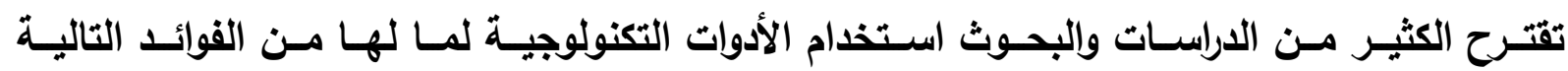

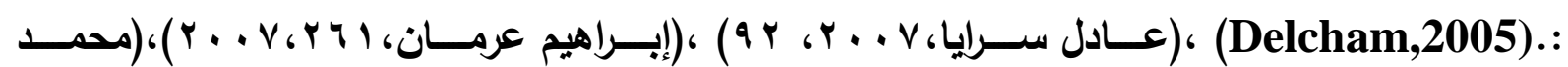




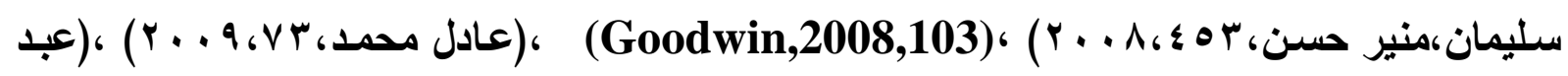

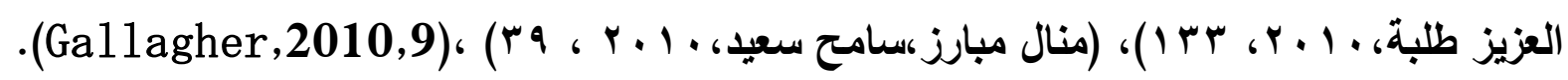

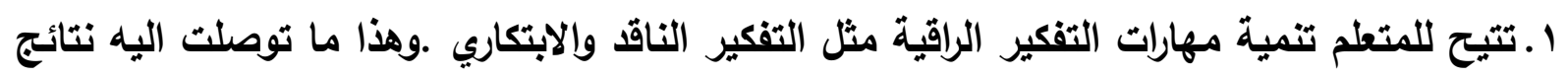

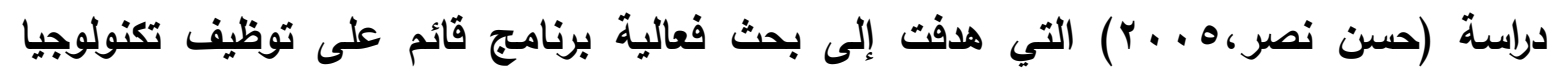
الوسائط المتعددة الكمبيوترية التفاعلية في تنمية التحصيل ومهارات التفكير الابتكارى فى الهندسة لهنة لاى تلاميذ الصف الثالث الاعدادي. r.تساعد على بقاء أثر التعلم وانتقاله حيث أن المتعلم يستطيع أن يتذكر .r\% مما بيمعه

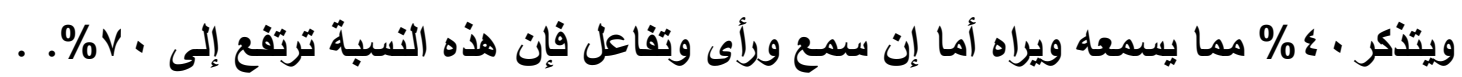
r.تؤدي إلى نوع من التعلم النشط ذي المغنى الذي يساعد الطلاب على اكتساب الحقائق والمفاهيم

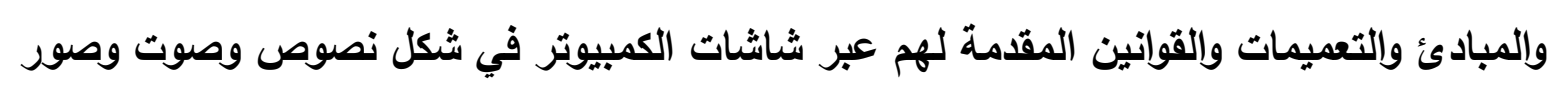

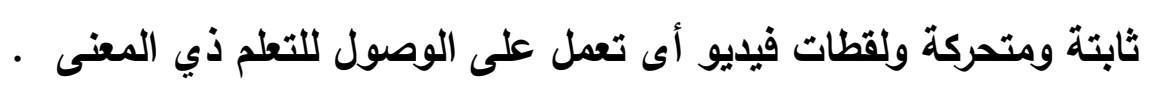

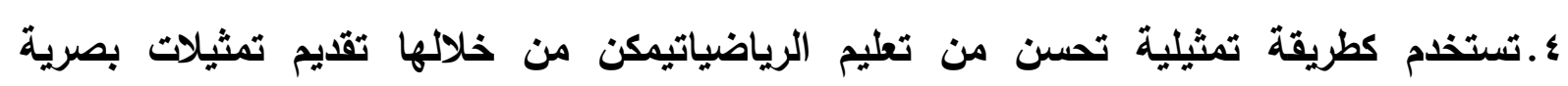
ديناميكية، وإتاحة تصوير واضح أكثر للمفاهيم الرياضية.. هـ تنمية الاتجاهات الايجابية نحو المادة الدراسية والمستحدثات التكنولوجية كما في دراسية سنجلتون(Singleton, 2009) التي هدفت إلى بحث أثر استخدام الوسائط المتعددة التفاعلية في تنمية الاتجاهات نحو الرياضيات وفههرم للاوال الأسية لطلاب المرحلة الثانوية. 4. يمكن للطلاب التعامل بالفعل مع التمثيلات على الثاشة أو توليد التمثيل الخاص بهم لزيادة فهمهم للمفهوم رياضي .وهذا ما حقتته دراسة دلكهام (Delcham, 2005) التي هدفت إلى بحث أثر بكث

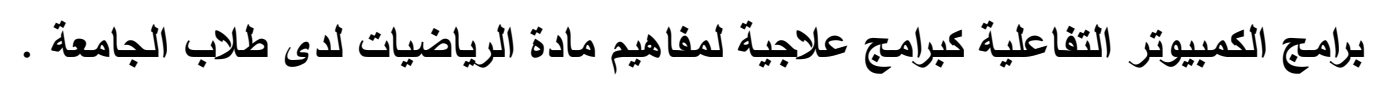
V. تؤدي إلى زيادة تحصيل الطلاب في الرياضيات عند استخدام (IWBs) وهذا ما توصلت إليه دراسة هوجينز (Huggins,2012) التي هدفت إلى تقييم فعالية نظام الوسائط المتعددة الكمبيوترية على الكفاعة الذاتية ومخرجات التعلم لاى تلاميذ المرحلة الاعدادية في مادة الرياضيات (الجبر).

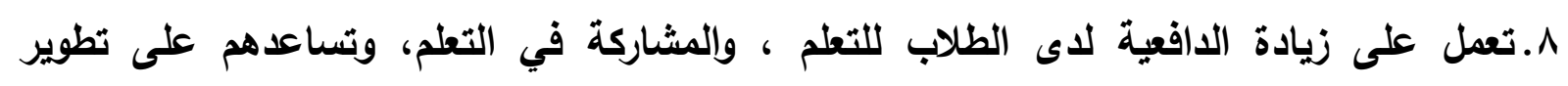

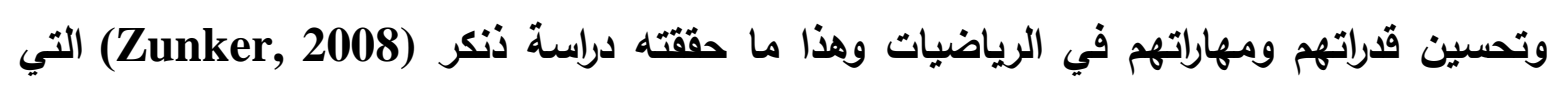
هدفت إلى تحديد فعالية برامج الكمبيوتر متعددة الوسائط على تطوير مهارات الرياضيات مثل فيات 
(أساسيات العد والجمع، الطرح) لاى تلاميذ المرحلة الابتدائية ذوي صعويات التعلم وأيضا التعرف على مستوى الافقعية نحو تعلم الرياضيات. 9. تعمل على تعزيز وتيسير تعلم المفاهيم كما تؤدي إلى تطلم المفاهيم الرياضية بمعدل أسرع وهذا ما لتونيات توصلت إليه نتائج دراسة ماليك (Malik,2010) التي هدفت إلى بحث تأثير تكنولوجيا الوسائط المتعددة التعليمية في تمكن طلاب الصف التاسع من مفاهيم الجبر. ودراسة (هشام بسيوني، r r r r التي هافت إلى التعرف على فعالية برنامج متعدد الوسائط لتنمية المفاهيم الرياضية للتلاميذ ذوي صعويات التعلم بالمرحلة الابتدائية وتنمية الاتجاهات الايجابية نحو مادة الرياضيات.

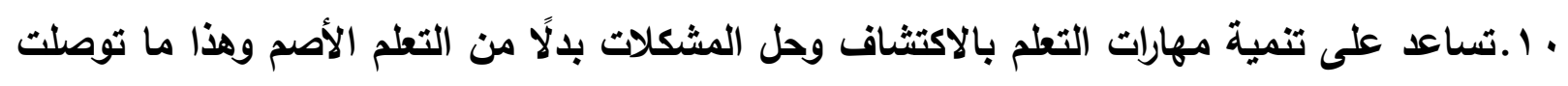
إليه دراسة دلجادو(Delgado,2007) التي هدفت إلى بحث فعالية تكنولوجيا الوسائط المتعددة في

$$
\text { القدرة على حل المشكلات في مادة الرياضيات . }
$$

11.تعمل على إثارة الدافعية نحو التعلم وتوفير الحافز وتهيئة الظروف المناسبة للتعلم، كما أنها تستدعي الخبرات السابقة وتمد المتعلمين بخبرات تساهم في تنشيط استجابة المتعلم وقيامه بدور ايجابي وإكسابه مهارات متنوعة وتعديل اتجاهه وتنمية ميوله . وهذا ما أكدتة دراسة بيرجان (Birgan, 2010) واتجاهات الطلبة لتعلم الرياضيات.

؟) خصائص الوسائط المتعددة التفاعلية تتميز الوسائط المتعددة التفاعلية بمجموعة من الخصائص جطلتهانها تتناسب مع عملية التعلم

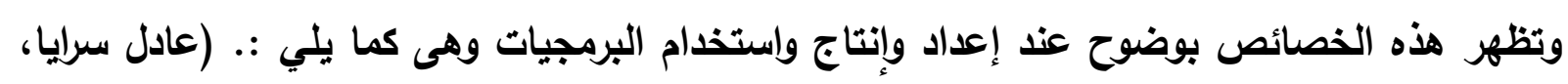

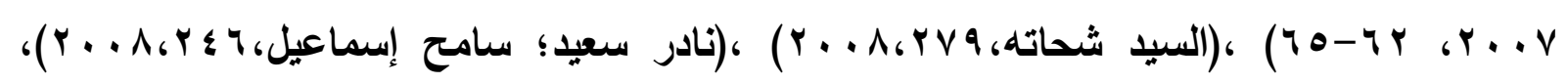

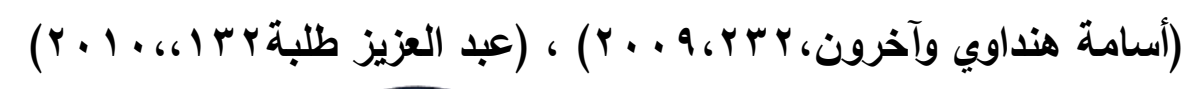

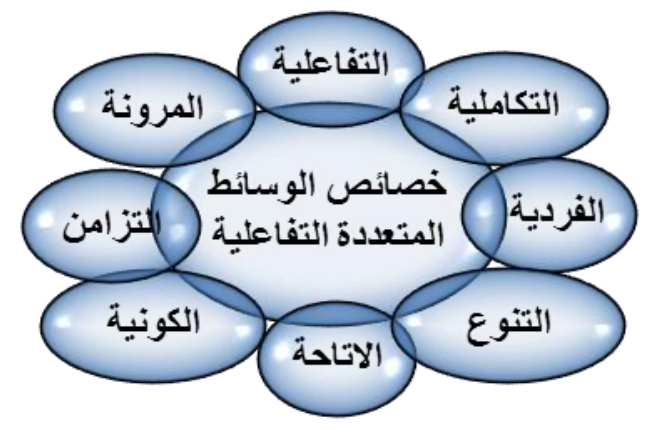

شكل (ץ) خصائص الوسائط المتعددة التفاعلية 
1. التفاعلية Interactivity:. وتعني تجاوب المتعلم مع البرنامج من خلال الإبحار داخل خرائط

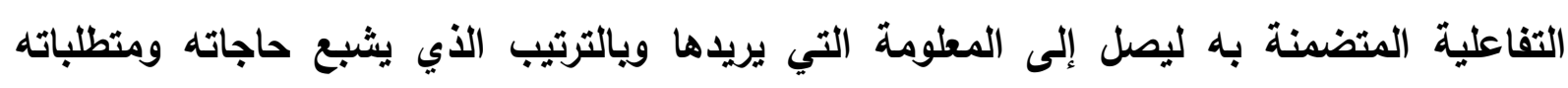
واختياراته واهتماماته.

r. التكاملية Integrity:. ويقصد بالتكاملية أن جميع عناصر البرنامج ووحداته تتحد معا لتقيم صورة مثلى له وتعتمد قوة برنامج الوسائط المتعددة التفاعلية على مدى تكامل العناصر المئه المختلفة المكونة له من رسومات ونصوص ولقطات فيديو ومؤثرات صوتية بأنواعها المختلفة في إطار نسقي لئي واحد لتحقيق الهـف المنشود. r. الفردية Individuality:. وتعني تفريد المواقف التعليمية لتناسب المتعمين من حيث قدراتهم

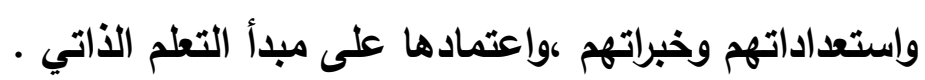

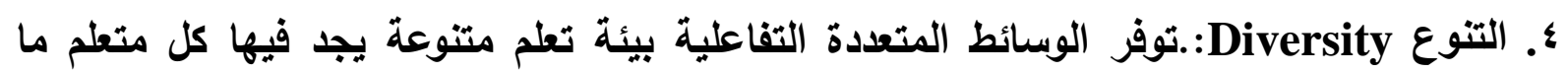
يناسبه ومن خلالها يمكن تقايم تثكيلة من المثيرات التي تخاطب الحواس المختلفة من صور متحركة لونة أوثابتة والنصوص المكتوية والمسموعة والموسيقى والمؤثرات الصوتية والرسومات والتكوينات الخطية بكافة أثكالها ويرتبط تحقيق التنوع بخاصية التفاعلية وخاصية الفردية . ه. الإتاحة Accessibility:

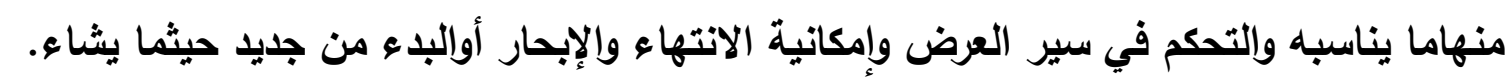

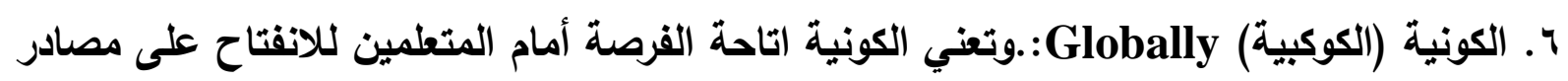

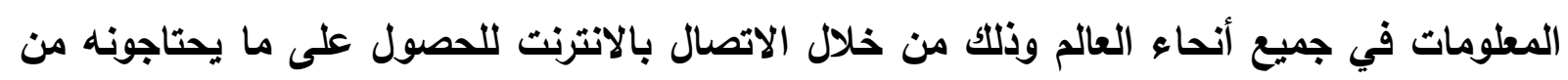

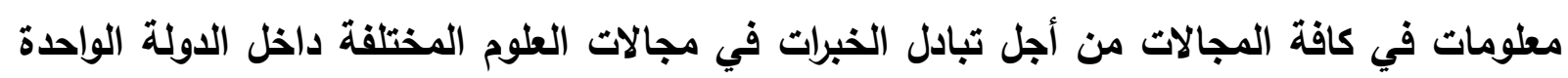

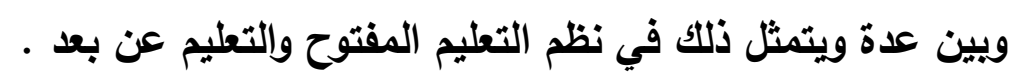

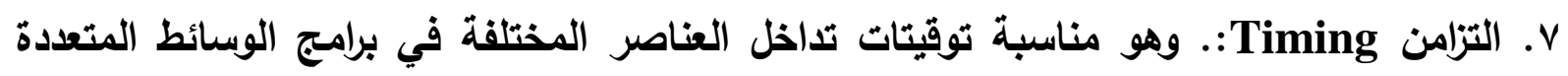

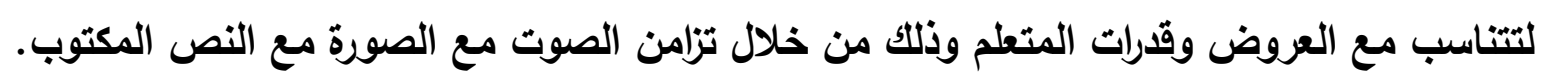

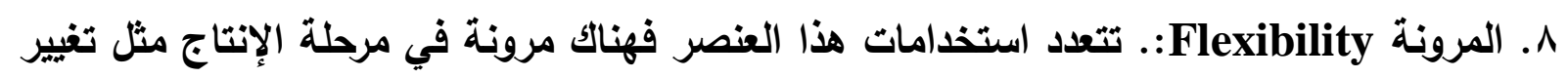

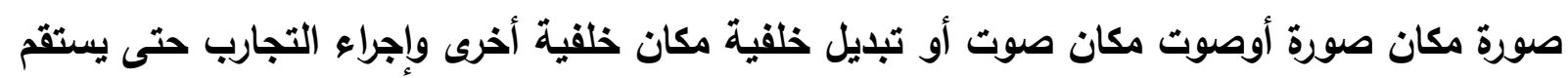

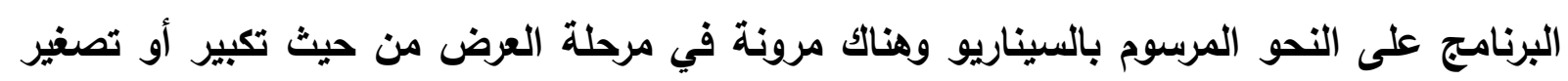

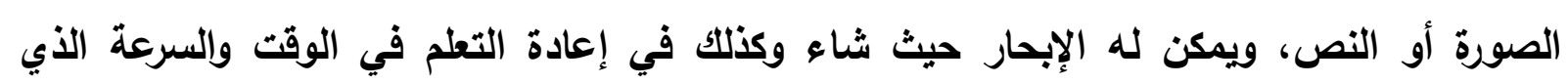




\section{الحهور الثالث :. التفكير الرياضي}

( ) ماهية التفكير الرياضي

لقد تعددت تعريفات ومفاهيم التفكير الرياضي ويرجع ذلك إلى اختلاف توجهات الباحثين

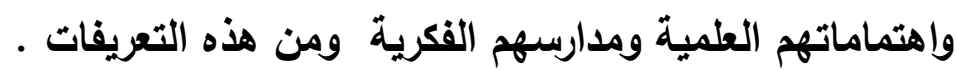
يعرفه بهزت (Behzet,2006) بأنه نثاط عقلي مرن ومنظم يهذف إلى إنى حل المشكلات الرياضية أو كل مكونات التفكير الرياضي وهى الاستقراء والاستتباط والتفكير الاحتمالي والتتعبير بالرموز والمنطق

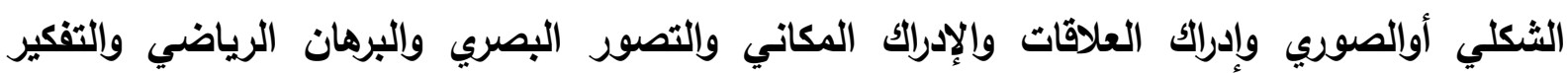
العلاقي وذلك حسب طبيعة كل مشكلة رياضية .

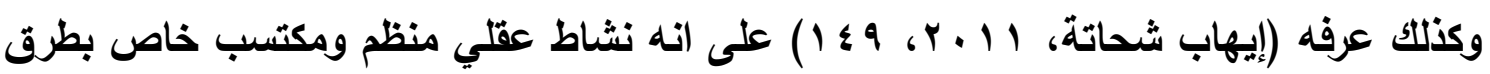

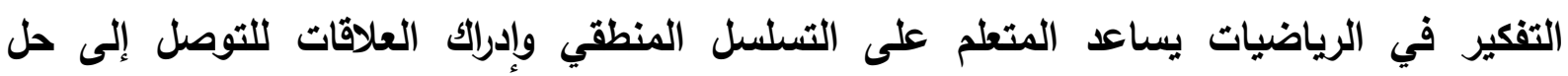

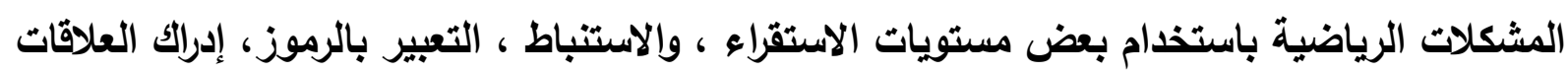

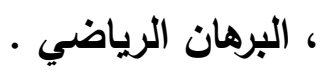

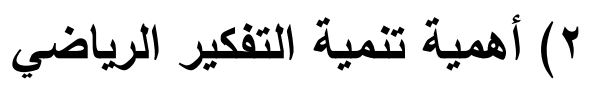

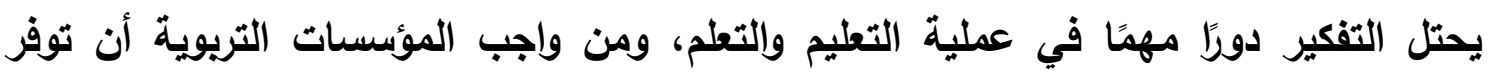

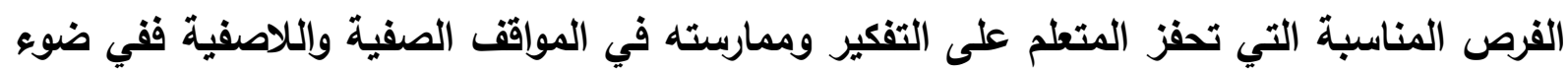

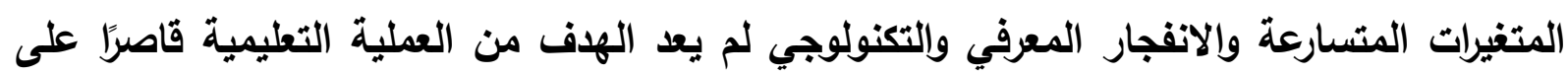

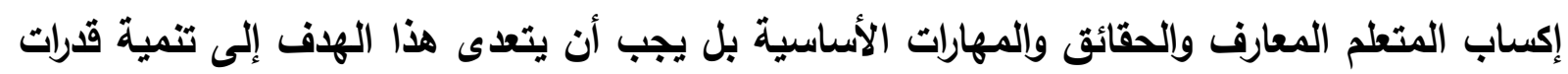

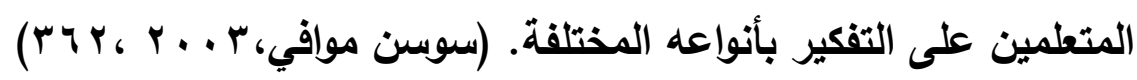

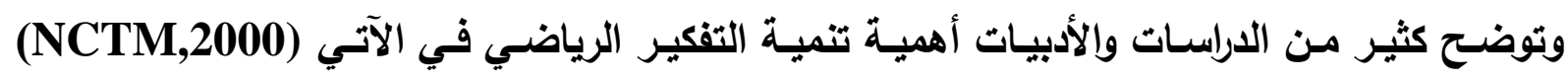

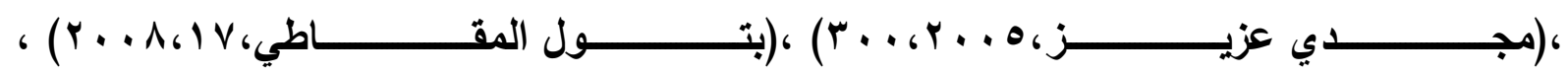

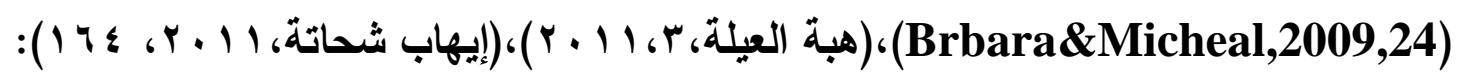
ا.يُعد التفكير الرياضي أحد الأهداف الرئيسة لتعليم وتعلم الرياضيات لجميع التلاميذ في كافة مستويات التعليم وفي كافة المراحل العمرية.لأنه لا يقتصر على مجرد البرهان الثكلي ولكنه يتضمن مجالًا واسعًا من القدرات التي يجب على التلاميذ أن يمتلكوها ويتمكنوا منها مثل "تطبيق التفكير الاستنباطي والاستقرائي"، و"فهم وتطبيق عمليات التفكير،ويصفة خاصة التفكير المكاني"، و"إصدار

$$
\text { أحكام على صدق وصحة البراهين والحجج". }
$$

r. ينظر إلى التفكير الرياضي بأنه السبيل الذي أسهم في تطوير الفكر الرياضي لإدراك أهمية العمليات

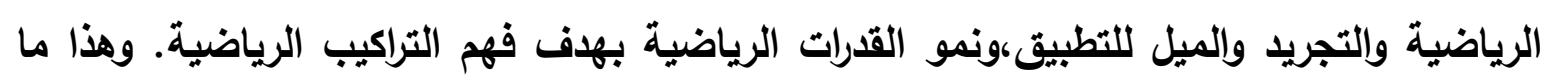


هافت إليه دراسة بابو وآخرون( Pape \& Bel \& Yetkin,2003) إلى تطوير التفكير الرياضي لئيس

والتنظيم الأت باستخدام الانشطة الاثرائية. r.التفكير الرياضي يعتبر حجر الأسساس في تطور الرياضيات لأن من خلاله يتم إدارك العلاقات الرياضية المجردة ,وفهم التطبيقات الرياضية،والوصول لأعلى المستويات تجريدا، وان نمو القدرات الرياضية لدى الطلاب يعتمدعلى تنمية مهارات التفكير الرياضي لايهم ع ـ تنمية التفكير الرياضي سمة أساسية تساعدالإنسان في التفاعل مع مواقف الحياة المختلفة وتمكنه من حل المشكلات التي يواجهها في الأوضاع التعليمية والحياتية المختلفة،كذلك مساعدة الأفراد علي الاستمرار في دراستهم بجانب إعدادهم للحاضر والمستقبل وهذ هو أحد الأهداف التربوية التي

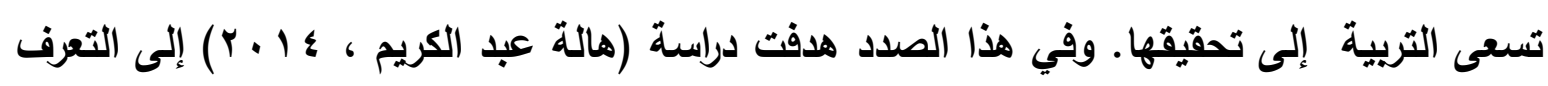
على فاعلية برنامج مقترح قائم على التواصل الرياضي في تتمية مهارات التفكير الرياضي والمهارات الحياتية لتلاميذ الصف الخامس الابتدائي . ه. التفكير الرياضي يغير دور المتعلم من المستقبل للمعلومات إلى المتعلم النشط الذي يبحث عن المعلومة وينمي مهارات الاكتثاف وحل المشكلات لاى المتعلمين . 7. يختلف عن أنواع التفكير الأخرى بوجه عام حيث يشتمل مصطلحات محدة تحديدًا دقيقًا من حيث

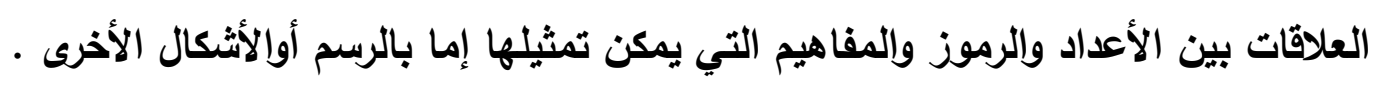

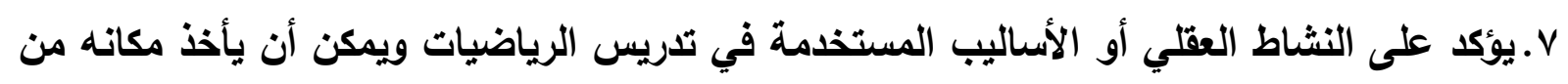

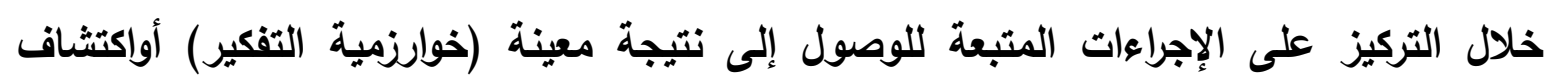
القاعدة (النمط) التي تنظم أو تبنى بعض المطلومات أو استخدام الطرق الثكلية أوغير الثكلية

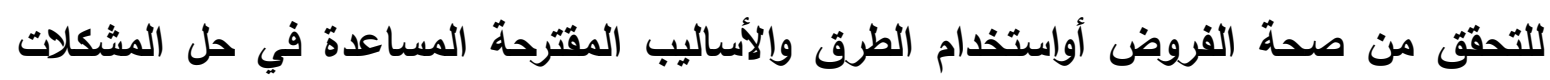
بوجه عام أوالاستقراء في تكوين العلاقات أواستخدام المنطق الثكلي . ^. يعمل التفكير الرياضي على زيادة دافعية المتعمين لتعلم الرياضيات وتتمية قدرات المتعلم على إكساب الفرد الأسلوب العلمي الصحيح في حل المشكلات الرياضية التي تواجهه من خلال إعادة صياغة المشكلة الرياضية واتباع الأسلوب العلمي السليم في البحث عن حلول لتلك المشكلة ومن ثم تقويم الحلول التي توصل إليها لحل تلك المشكلة. ومن الدراسات التي اهتمت بتنمية التفكير الرياضي في المرحلة الابتدائية دراسة بوريز (Burris,2010) 
القيمة المكانية للأعداد من خلال التدريس بالمواد اليدوية الملموسة والواقع الافتراضي من خلال

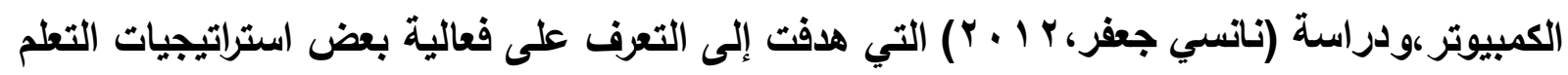

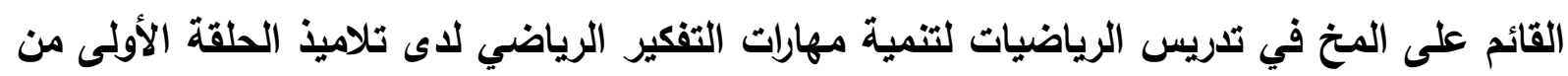

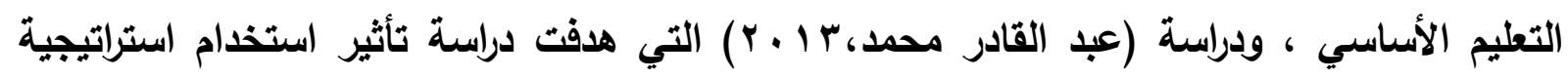

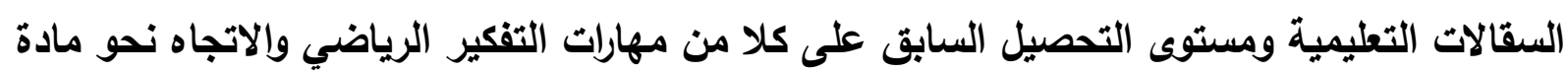

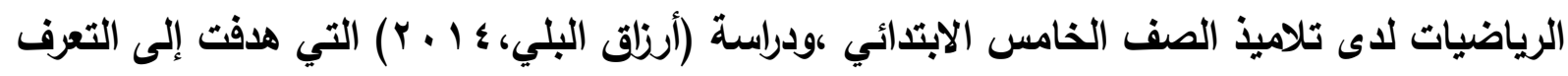

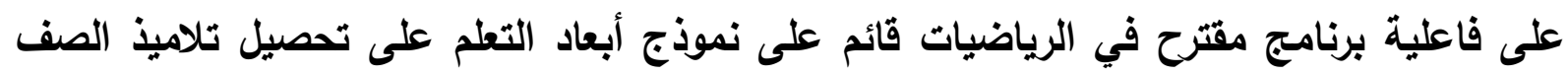

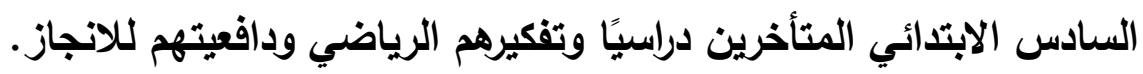
r) مهارات التفكير الرياضي ولقد أكلت العديد من الدراسات والبحوث التي اهتمت بتدريس الرياضيات أن التفكير الرياضي

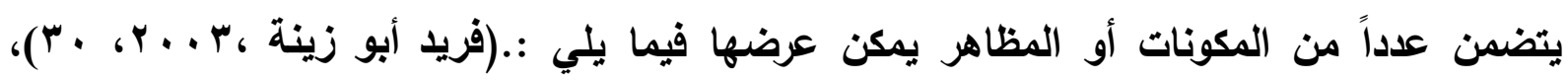

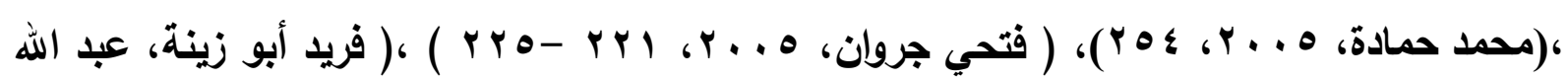

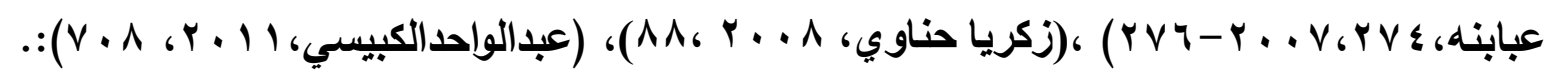

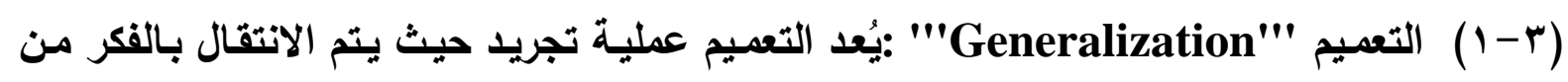

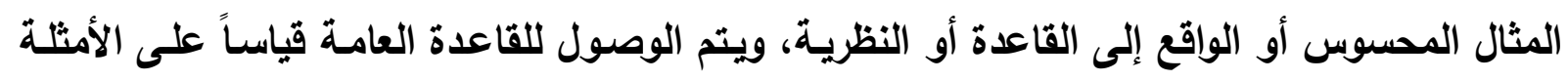

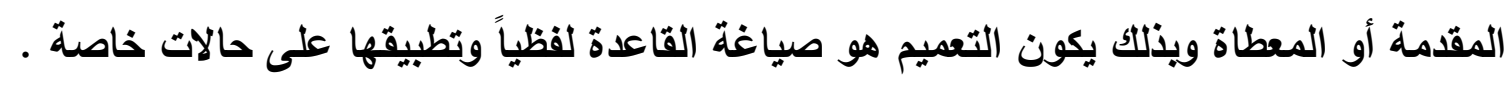

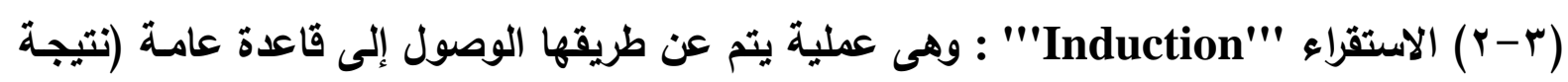

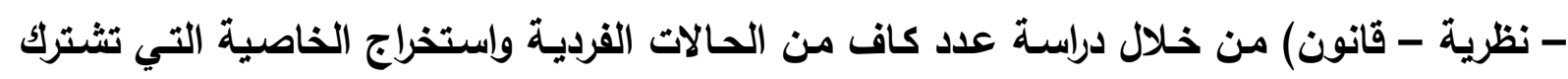
فيها هذه الحالات.

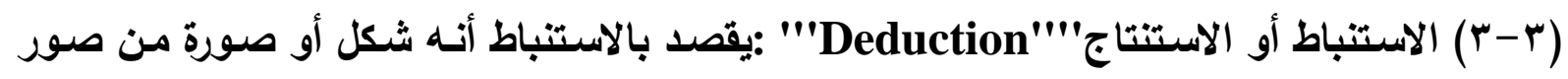

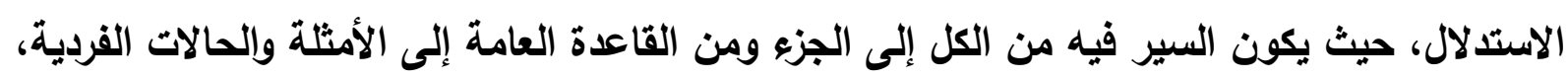

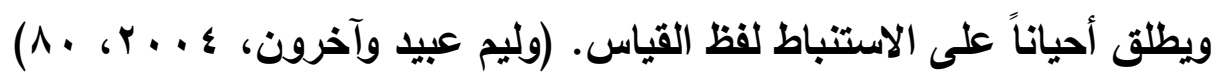

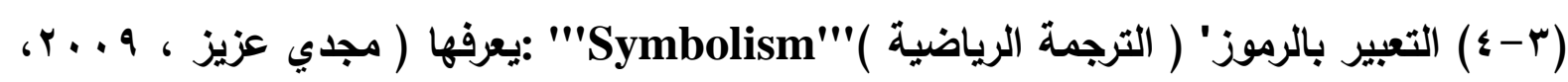
9 1) يقصد به استخدام الرموز للتعبير عن الأفكار الرياضية أو المعطيات اللفظية ، ومن الأمثلة:

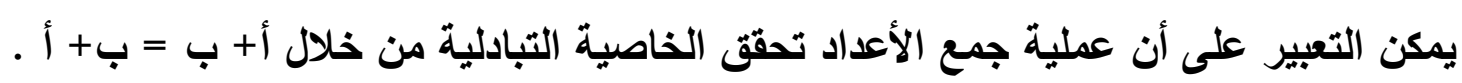

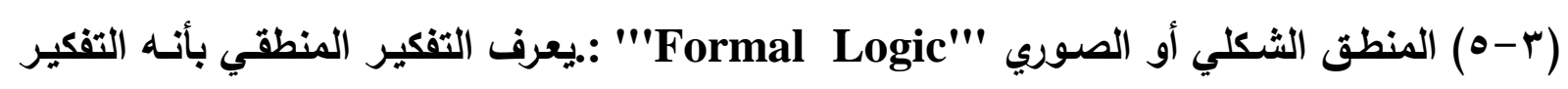

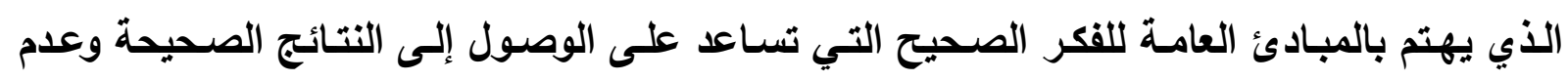

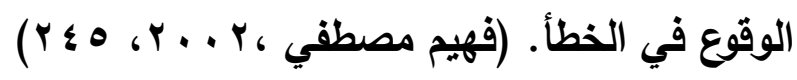




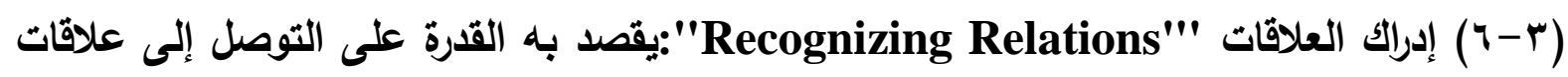
استتاجيه بين المقدمات والتتائج وإقامة التعليلات والبراهين المنطقية للتوصل إلى الحلى الحله

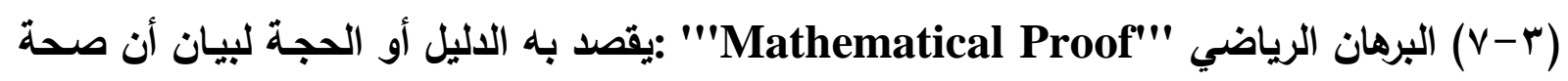

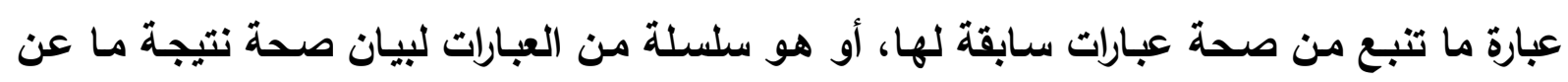

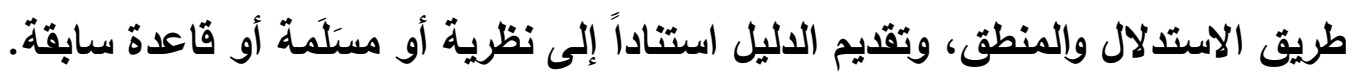
(Word Problem Solving المسألة الرياضية موقف جديد

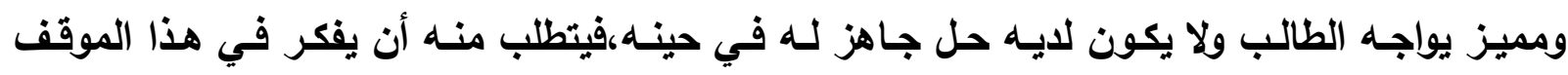
ويحلله،ومن ثم يستخدم ما تعلمه سابقا من معرفة رياضية لإيجاد الحل المناسب لهذا دله الموقف.

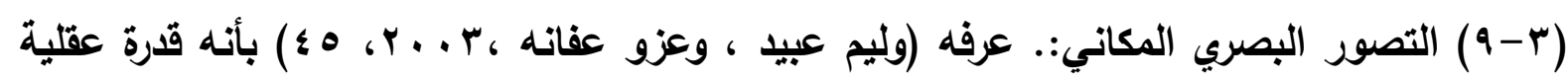

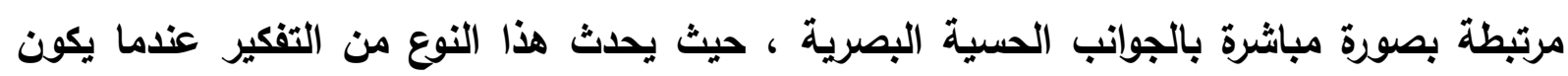

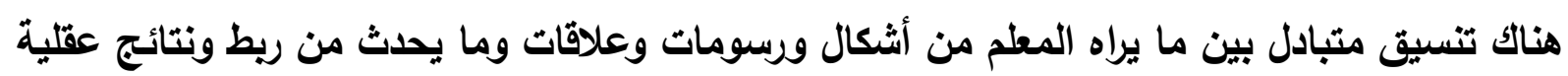

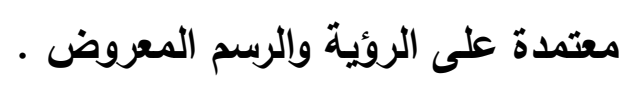

\section{الحمور الرابع : بطيئي تعلم الرياضيات}

$$
\text { التلاميذ بطيئي التعلم في الرياضيات }
$$

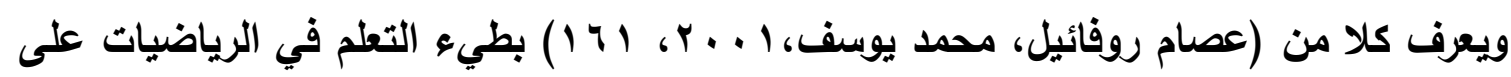

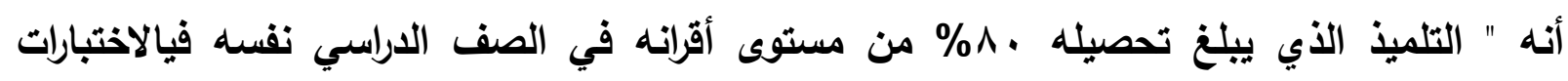

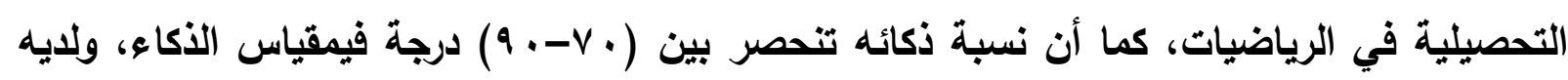
اتجاه سلبي نحو الرياضيات. وأيضا يعرف (John,2001,148) بطيء التعلم في الرياضيات على أنهم مجموعة التلاميذ ذوي الرياضيات نسبة الذكاء أقل من المتوسط وتحصيلهم في مادة الرياضيات أقل من مستوى تحصيل زملائهم في في الفيات نفس مستوى الصف الدراسي

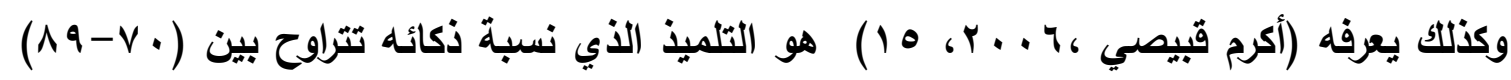

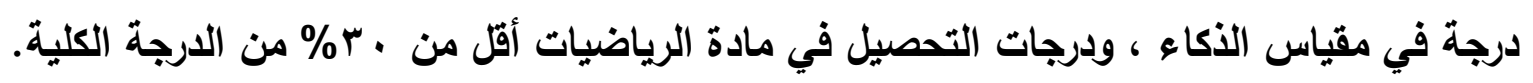
والثكل التالي يوضح من هو التلميذ بطيئ تعلم الرياضيات

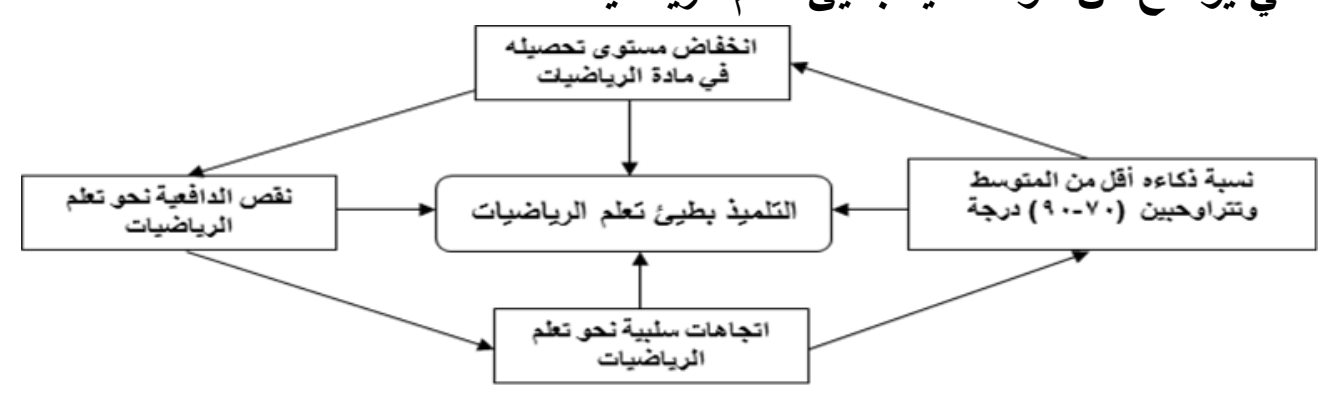

شكل رقم (ץ) يوضح ما هو التلميذ بطئ تطلم الرياضيات 
خامسيًا :. خصائص وسمات بطيئي التعلم :

يتسم التلميذ بطيئو التعلم بعدة سمات تميزهم عن غيرهم من التلاميذ ومن أهم هذه السمات ما

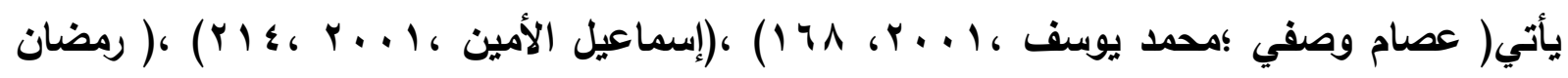

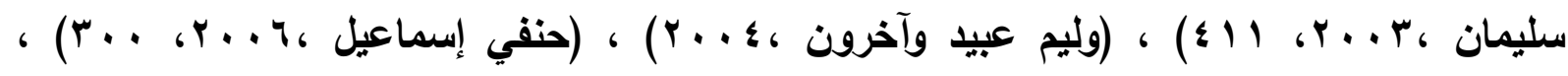

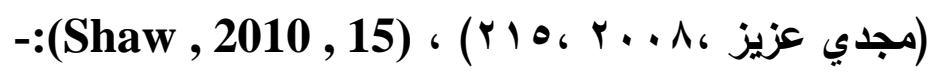

ا ـ يعاني بطيء التعلم من انخفاض مستوى تحصيله الدراسي في مادة الرياضيات عن تحصيل زملائه العاديين ويالتالي يصبح لايه نقص في الافافع نحو تعلم الرياضيات.

ץ. يشعر دائما بالفشل عند دراسته لمادة الرياضيات ولا يثق في نفسه أثناء حل المسائل الرياضية .

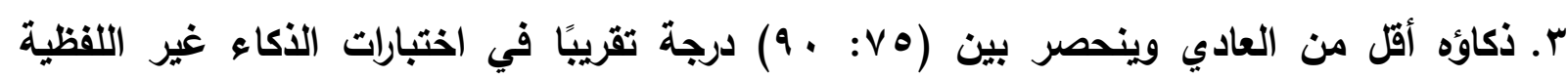

$$
\text { الفردية أو الجماعية. }
$$

ع. لايه صعويات في الاستنتاج والوصول إلى نمط أو تعميم رياضي وفي تذكر الحقائق والعلاقات. هـ لايه صعوية في القراعة بصفة عامة وقراعة الرياضيات بصفة خاصة . 7 . لا يستطيع تطبيق ما تعلمه من أفكار وتعميمات ومهارات رياضية في مواقف حياته . V. يميلون إلى حفظ قاعدة خاصة بكل نوع من المسائل مع قليل من الفهم للخطوات التي يتبعونها. ^. يحفظون براهين النظريات ولكنهم لا يستطيعون القيام ببراهين التمارين. 9. لا يستطيع أن يركز انتباهه أثناء الثرح لفترة طويلة أكثر من . د دقيقة تقريبا منصتًا للمدرس. ـ 1 ـ لايهم اتجاه سلبي نحو الرياضيات والهندة لا يستطيعون نقل أثر التعلم من موقف إلى موقف آخر في الفصل .

وتمثل خصائص التلاميذ بطئ التعلم بوجه عام ، وفي الرياضيات بوجه خاص موضع اهتمام عند التذريس باستخدام النماذج البنائية والوسائط المتعدة التفاعلية في البحث الحالي من ناحية وعند التعامل الانساتي مع بطئ التعلم أثناء التطبيق الفعلي من ناحية أخرى . وتعددت الدراسات التي تتوعت في استخدام الطرق والمداخل المختلفة للتدريس للتلاميذ بطيئي التعلم:. مثل دراسة (منال محروس، ج . . ب) الي هدفت إلى التعرف على فاعلية استخدام اسلويى "تحليل المهمة " والعمليات العقلية في حل مشكلات الحساب لاى تلاميذ الصف الرابع الابتدائي بطيئي التعلم. ودراسة (قصي توفيق غزال ودعاء أياد الخثاب، V . . r) التعرف إلى اثر استخدام اللعب بوصفه تقانه

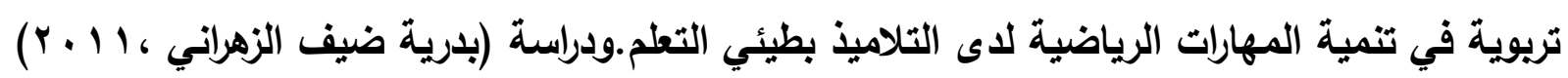


التي هافت إلى التعرف على أثر إستراتيجية حل المشكلات المعلية في تنمية التحصيل والتفكير

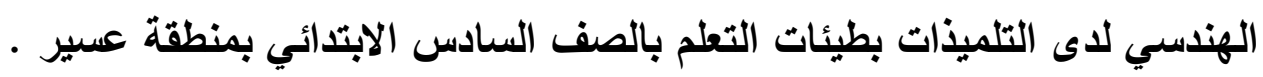

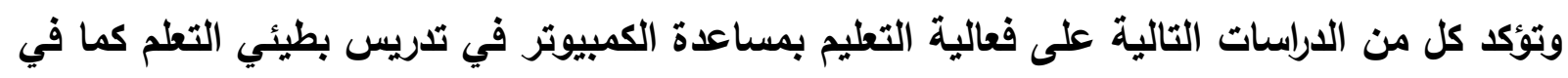

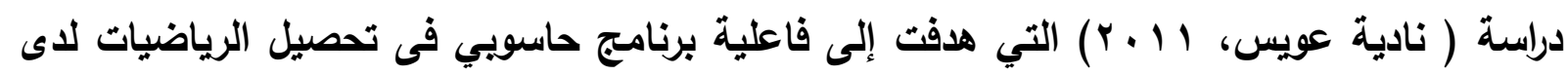

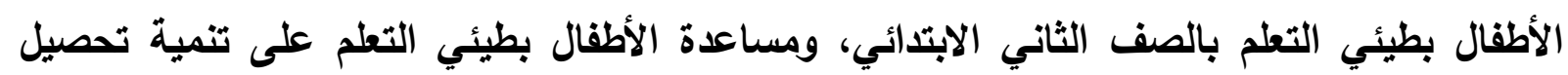

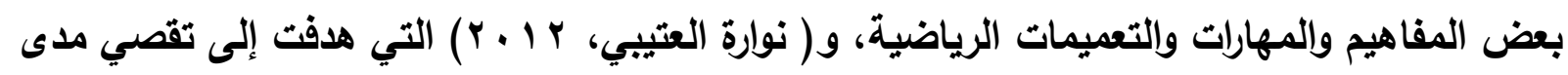

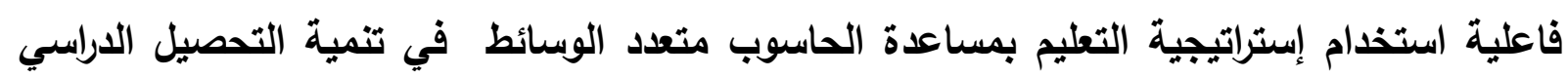

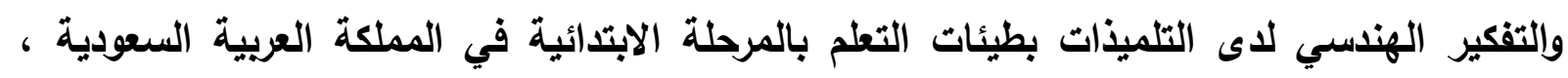

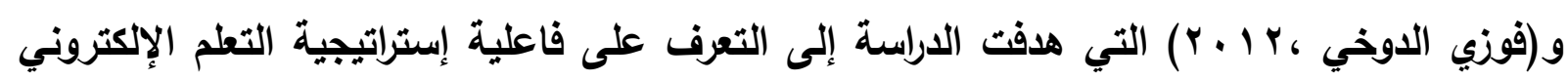

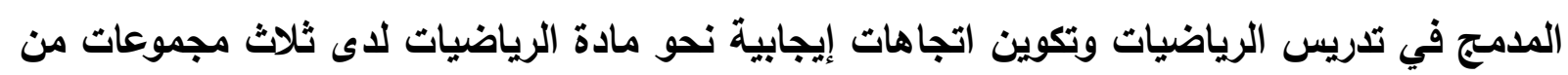
الطلبة ذوي الإعاقة هم ذوو صعويات التعلم ويطيئو التعلم ذوو الإعاقة الفكرية البسيطة. • هرضا البحث :.سبوف تقوم الباحثة بالتحقى من صحة الفروض التالية :ا. يوجد فرق دال إحصائيًا (ل>0.,.) بين بين متوسطى درجات تلاميذ المجموعة الضابطة التي تدرس بالطريقة المعتادة ،والمجموعة التجريبية التي تدرس النموذج البنائي التكاملي باستخدام الوسائط

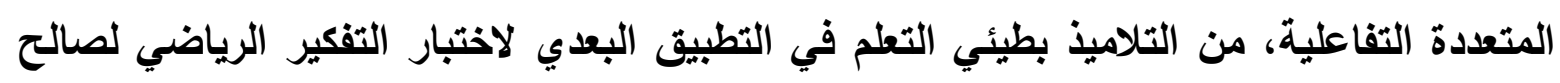

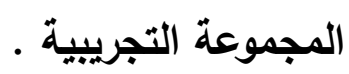
r.يوجد فرق دال إحصائيًا (ل>ه.,.) بين متوسطات درجات تلاميذ المجموعة الضابطة التي تدرس بالطريقة المعتادة ،والمجموعة التجريبية التي تدرس النموذج البنائي التكاملي باستخدام الوسائط المتعددة التفاعلية من التلاميذ بطيئي التعلم في التطبيق البعدي لمقياس الدافعية نحو تعلم الرياضيات لصالح المجموعة التجريبية

\section{* إجراءات البحث}

للاجابة على تساؤلات البحث والتحقق من فروضه تم اتباع الاجراءات التالية :.

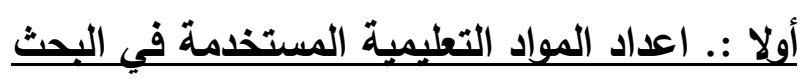
اعداد قائمة بمهارات التفكير الرياضي:. بعد الاطلاع على الأدبيات والداسات السابقة التي تناولت مهارات التفكير الرياضي للاستفادة منها في

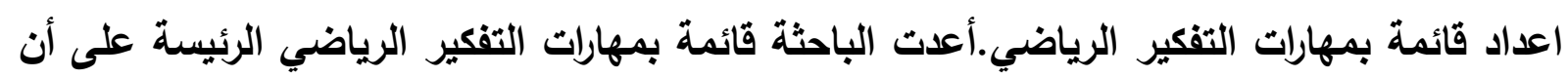

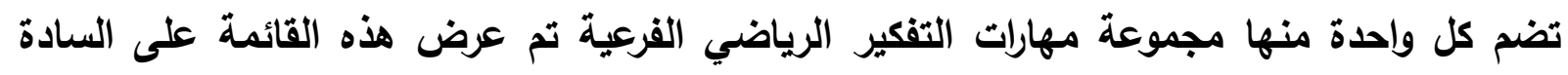


المحكمين لإبداء الرأى فيها ، وذلك قبل وضعها في صورتها النهائية وفي ضوء آراء الماء المحكين قامت

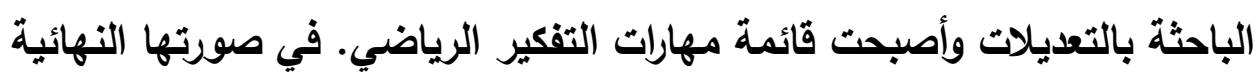
• إعداد البرنامج القائم على نموذج بايبي باستخدام الوسائط المتعددة التفاعلية

\section{تتحدد جوانب البرنامج ومقوماته فيما بلي :-}

التعريف بالبرنامج :. هو برنامج يعمل على رفع مستوى التحصيل الدراسي وتتمية بعض مهارات التفكير

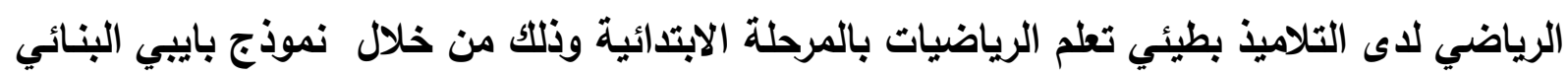

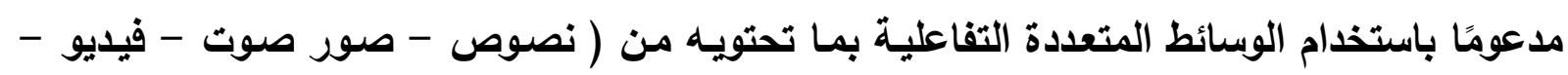
مؤثرات تفاعلية ) باستراتيجياتها المتعددة من ( تدريس خصوصي - تدريب ومران - محاكاة ) وغيرها.

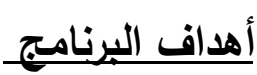
هناك هدف عام للبرنامج وأهداف تعليمية إجرائية محددة هي :.

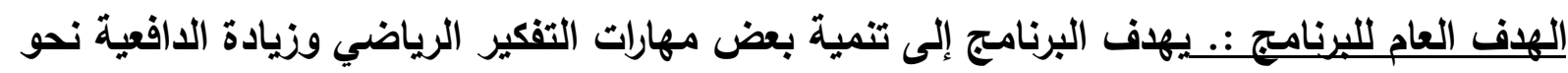

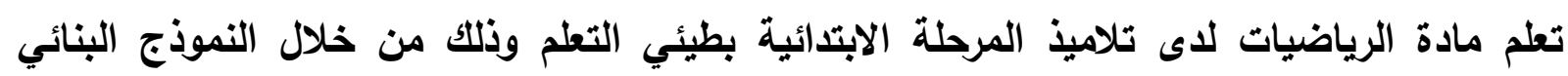

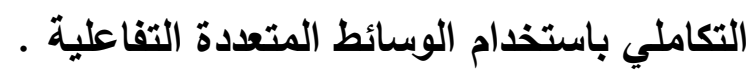

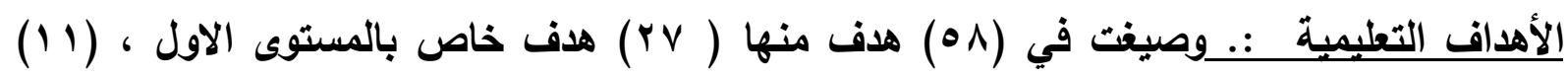

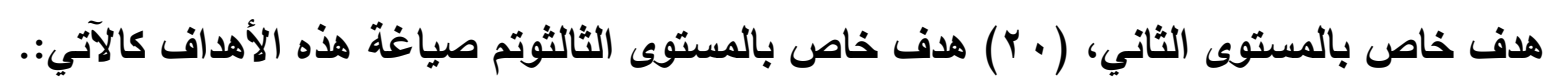

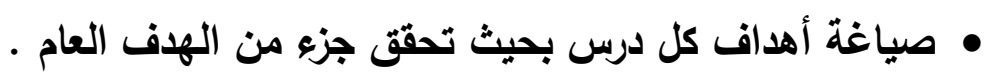
• صياغة الأهداف المعرفية وفقا للمستويات المعرفية الثلاث ،وهى المستوى الأول ( التذكر) ، المستوى الثاني (الفهم والاستيعاب) ، المستوى الثالث ( التطبيق) • مراحل البرنامج وهى ثلاث مراحل كما يحددها النموذج البنائي التكاملي كما يلي :.

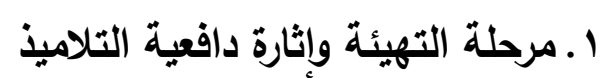
r ب إعلة إعادة بناء الأفكار r. مرحلة تنقيح وتطبيق الأفكار

المحتوى الدراسي_تم اختيار وحدتين من كتاب الرياضيات المقرر على الصف الخامس الابتائي وهما وحلتي " القياس "، و "التحويلات الهندسية " وذلك للأسباب التالية : . 1. تثنتمل دروس الوحلتين على كثير من المفاهيم التي يمكن إكسابها من خلال توظيف الوسائط المتعددة التفاعلية بطريقة تجعل التلميذ أكثر ايجابية وتفاعلية 
r. صياغة الوحدتين بحيث تثتمل على الكثير من التمارين المتنوعة التي تثير التفكير ولا تمثل

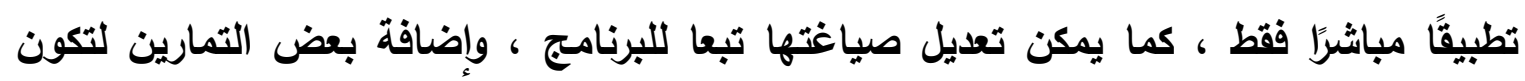

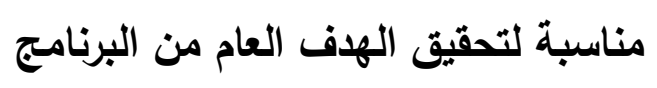

r. زمن تدريس الوحتثين كبير نسبيًا مما يعطي فرصة لإظهار تأثير البرنامج في تنمية كلاً من

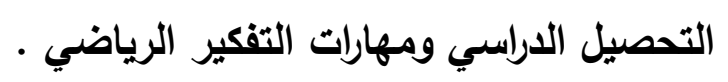

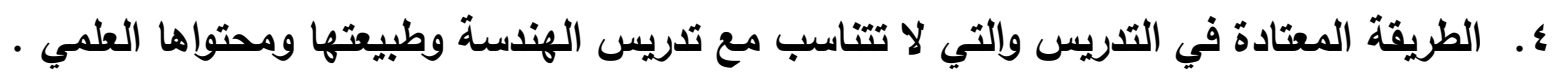

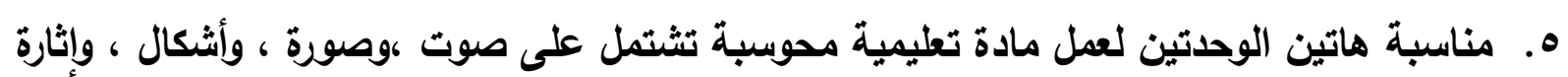
دافعية ويذلك يكون للحاسوب دور فعال وقوى في تدريس هاتين الوحدتين .

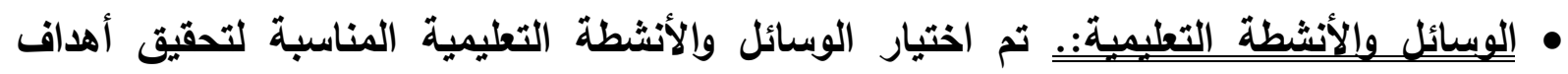

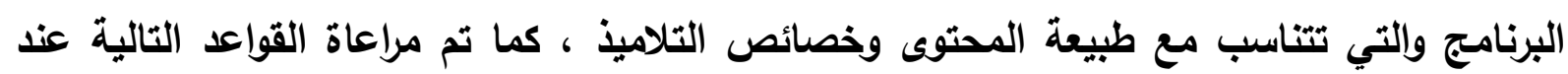

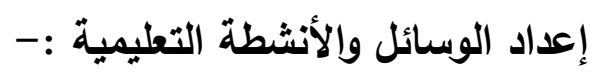

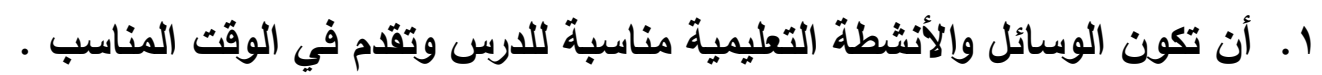

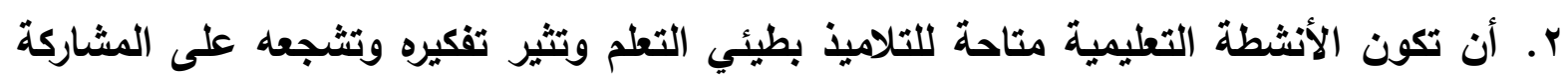

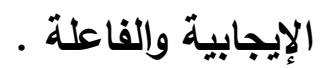

r. تدرج الأنشطة من السهل للصعب وتكون مناسبة لمستوى وخصائص التلاميذ بطيئي التعلم.

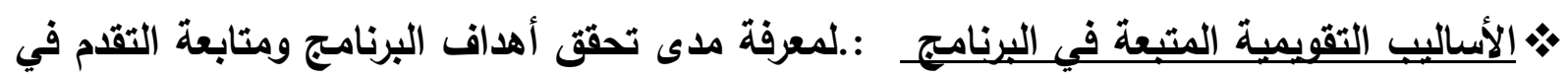

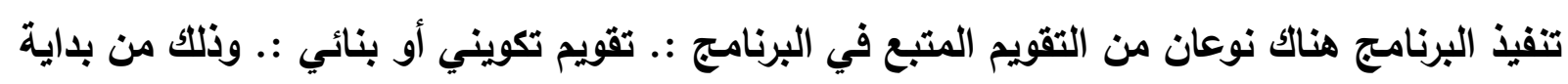

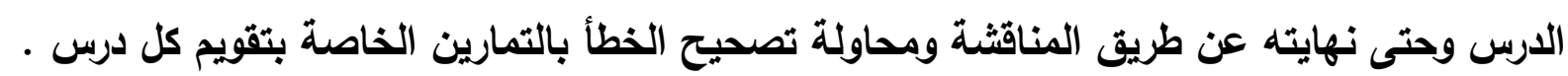

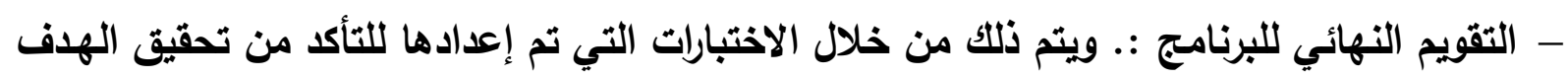

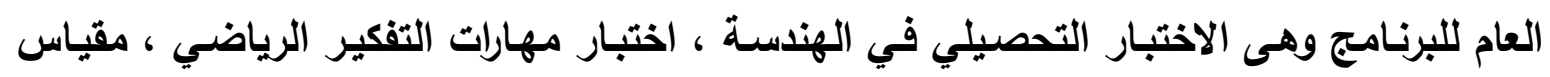

$$
\text { الدافعية نحو تعلم مادة الرياضيات. }
$$

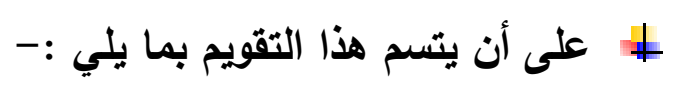

أ. الاستمرارية : وذلك من خلال أن يبدأ التقويم من بداية الدرس، وفي كل مرحلة حتى نهاية الدرس ونهاية الوحلتين . الاستمرابة : وذن ب. الثمول:. حيث يكون التقويم شامل لكافة جوانب التعلم المتضمنة في محتوى الوحدتي المختارتين.

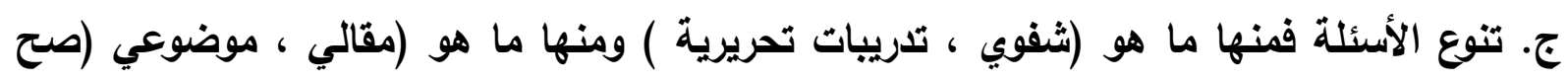
وخطأ ، تكملة ) د. احتوائه على بعض الأسئلة المرتبطة بمهارات التفكير الرياضي هـ مراعاته لجميع مستويات الأهداف التي تم تحديدها . 


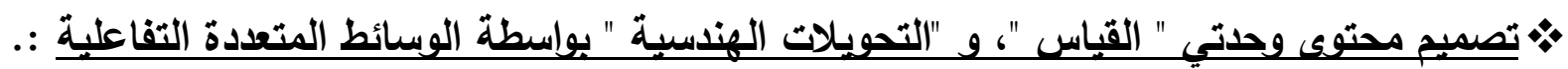

ومن ثم قامت الباحثة بوضع نموذج يوصف المراحل والإجراءات التي يجب أن تتبع عند تصميم برنامج

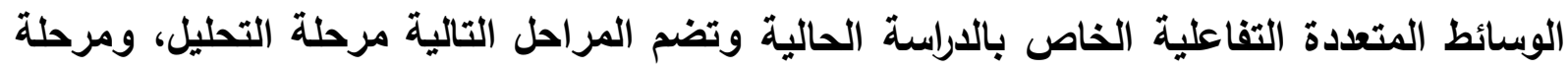

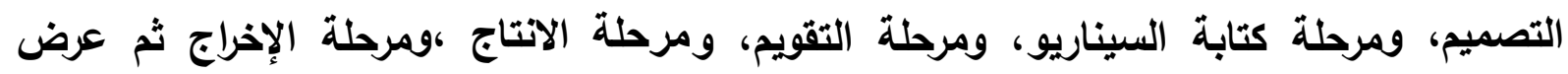

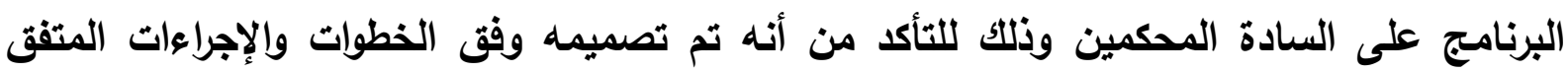
عليها وإضافة أى تعديلات في ضوء أراء السادة المحكمين حتى أصبح في صورته النهائية.

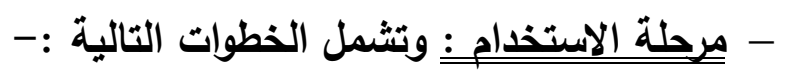
- توظيف البرمجية : وتعني استخدام البرمجية بتوزيع البرنامج على المجموعة التجريبية التي تدرس بالوسائط المتعددة التفاعلية وعددها (Y^) - المتابعة المستمرة : حيث تجري المتابعات المستمرة للبرمجية لمعرفة ردود الأفعال وإمكانيات التطوير المستقبلي. • • إعداد دليل المعلم لوحدتي " القياس" ، و" التحويلات الهندسية " باستخدام النموذج البنائي التكاملي

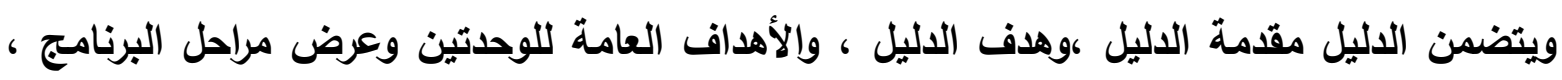
وشرح كل مرحلة فيه بخطواتها والاستراتيجيات المستخدمة ، عرض دروس الوحدتين وفقًا للبرنامج أما بالنسبة للكتيب فتضمن مقدمة ثم عرض الدروس وفقا للبرنامج متضمنه الدروس في الوحدة مع ترك فراغ للاجابة وتم برمجته الكترونيًا. • وتم عرض الاليل والكتيب على السادة المحكمين وقد تم التعديل في ضوء آرائهم ويذلك أصبح الاليل والكتيب في صورتهما النهائية .

\section{• إعداد أدوات البمث} إعداد اختبار التفكير الرياضي اتبعت الباحثة الخطوات التالية في إعداد اختبار التفكير الرياضي: التباري

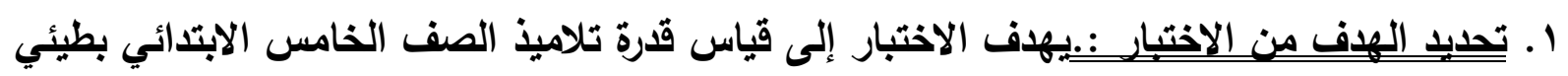

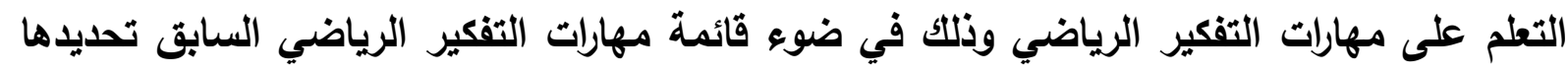

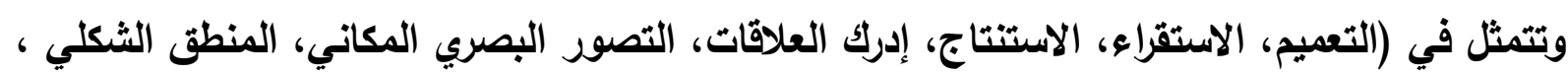
التعبير الرمزي) r. تحدبد مكونات الاختبار :. قامت الباحثة بالإطلاع على الدراسات والبحوث والأدبيات التربوية والتي

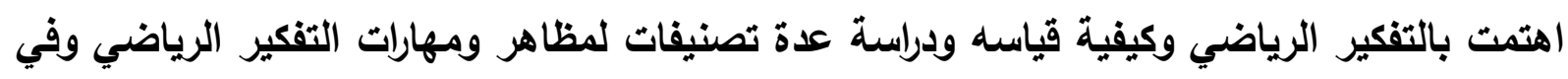


إطار الدارات السابقة ومن ثم أمكن تحديد عدد (سبعة) مهارات تتلاءم مع تلاميذ المرحلة الابتدائية

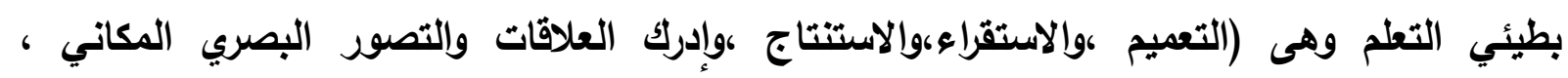
والمنطق الثكلي ،والتعبير الرمزي)

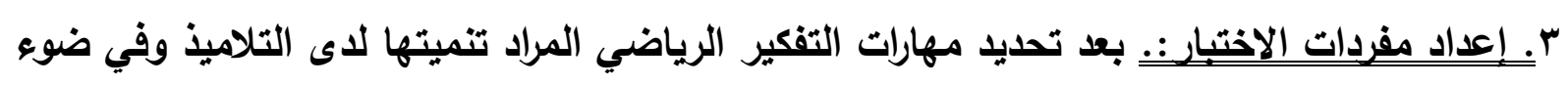

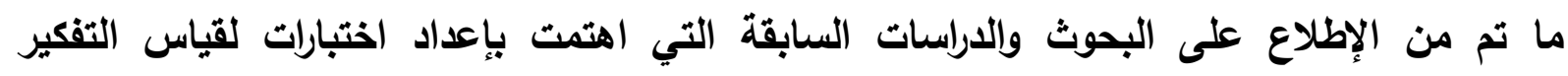

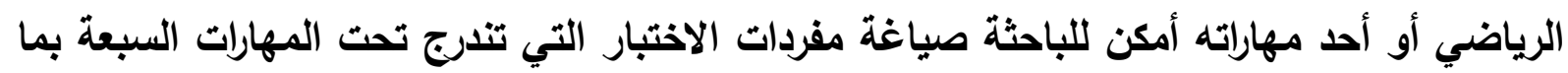

تحتويه من مهارات فرعية سبق تحديدها

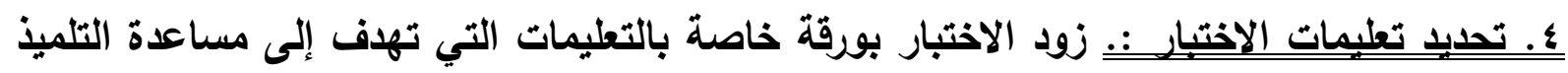

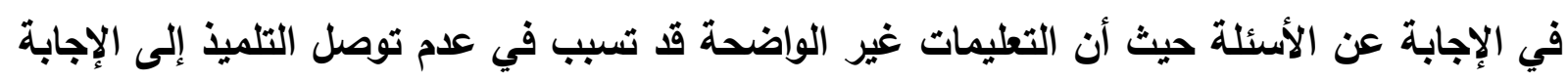

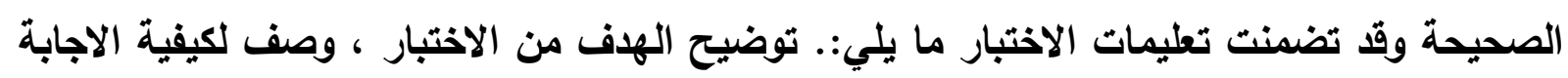

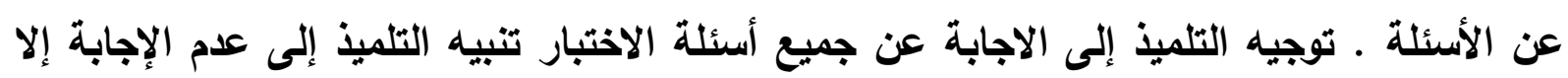

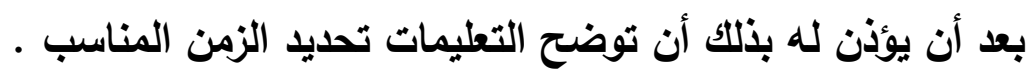
التجربة الاستطلاعية للمقياس وذلك لتحديد :. ثم تجرية انتبار التفكير الرياضي على العينة الاستطلاعية والتي عددها (•0) تلميذ وتلميذه من تلاميذ الصف الخامس الابتائي بطيئي التعلم

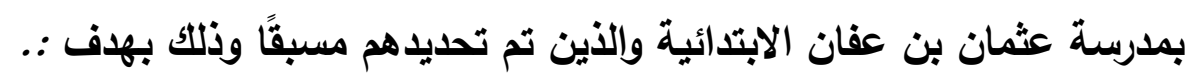

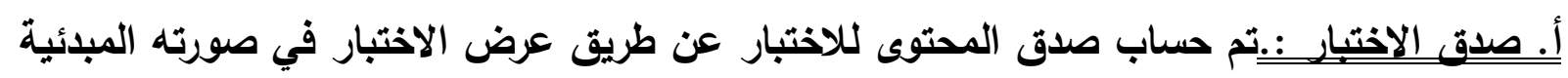

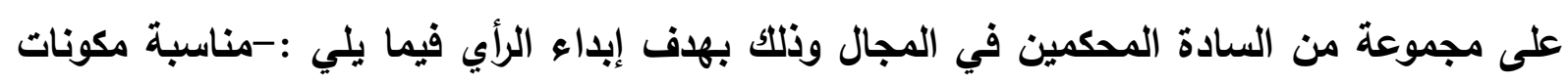

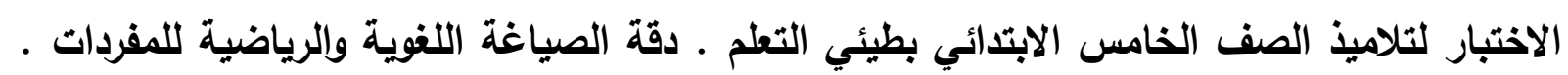

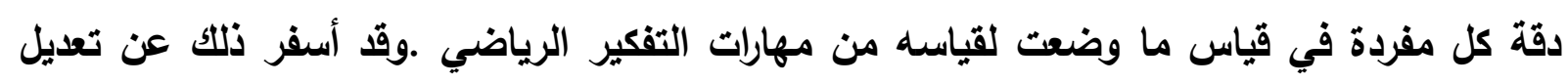

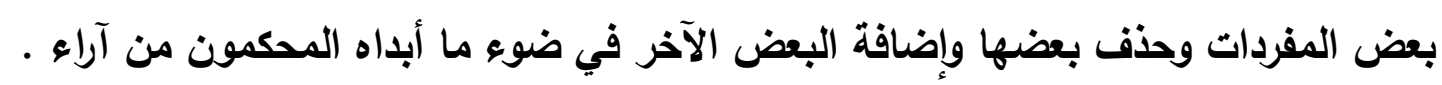

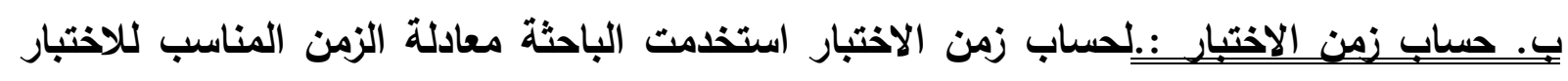

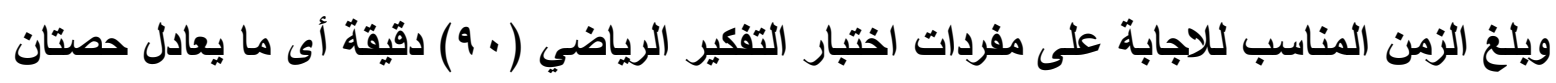

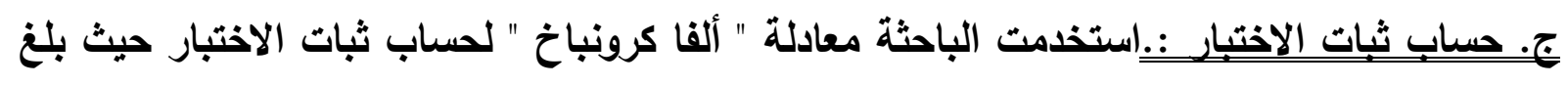
معامل ثبات الاختبار (1119, · · ) وهى قيمة مناسبة لثبات الاختبار كما تم حسابه بالتجزئة النصفين

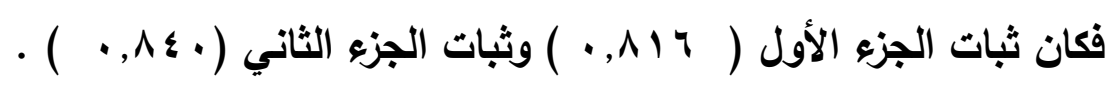

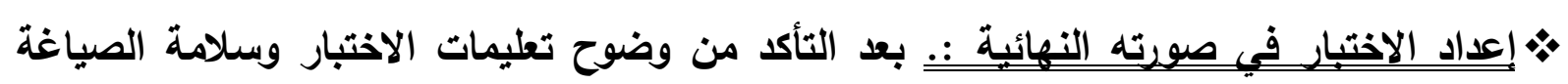
اللغوية ويعد الاطمئنان على صدق وثبات الاختبار من خلال عرضه على السادة المحكمين والتجرية

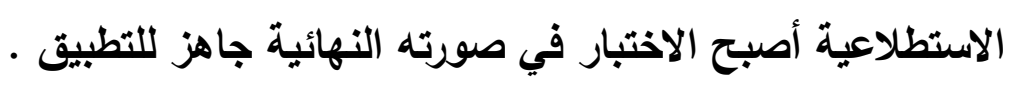




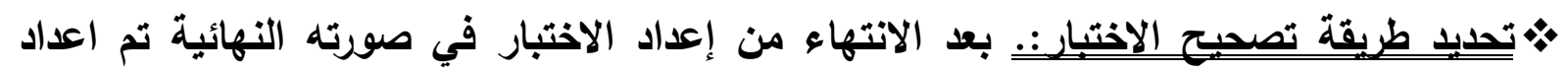
نموذج إجابة لكل مفردات الاختبار ويتم تصحيح الاختبار بأن تحسب درجة واحدة فقط لكل إجابة صحيحة ، وصفر لكل إجابة خطأ. • إعداد مقياس الدافعية نحو تعلم مادة الرياضيات :.وقت مرت عملية بناء المقياس بالخطوات التالية :• تحديد الهيف من المقياس: يهدف هذا المقياس إلى التعرف على دافعية تعلم تلاميذ الصف الخامس الابتائي بطيئي التعلم (مجموعة البحث) نحو مادة الرياضيات من خلال الاستجابات التي يبديها

$$
\text { التلاميذ على عبارات المقياس. }
$$

• تحديد أبعاد المقياس:. بعد الإطلاع على الداسات والبحوث السابقة وما تضمنته من مقاييس للادفعية نحو المواد الدراسية المختلفة بصفة عامة ونحو مادة الرياضيات بصفة خاصة واستطلاع أى مجموعة من السادة المحكمين في أبعاد المقياس المقترحة ومن خلال ما سبق أمكن تحديد ثلاثة أبعاد رئيسه لدافعية التعلم نحو مادة الرياضيات في الآتي :. السعى والمثابرة لتعلم مادة الرياضيات،الاهتمام والاستمتاع بمادة الرياضيات ، والحوار والمناقثة الصفية ويندرج تحت كل بعد الهدي من هذه الأبعاد مجموعة من العبارات التي تحدد دافعية تلاميذ الصف الخامس الابتدائي ( بطيئي

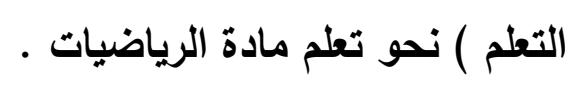

• تحدب نوع المقباس :تم اختيار طريقة ليكرت Likert - type Scale) لقياس دافعية تلاميذ الصف الخامس الابتائي بطيئي التعلم نحو تعلم مادة الرياضيات وذلك لما يتميز به من حيث قرة

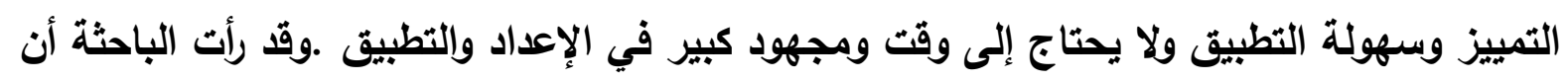
تكون الاستجابات على عبارات المقياس ثثلاثية (موافق- متردد - غير موافق) وذلك لتتناسب معتلاميذ الصف الخامس الابتدائي (بطيئي التعلم ) • تحبلب عبارات المقباس وصبياغتها :.استعانت الباحثة في صياغة عبارات المقياس بمجموعة من الاراسات التي اهتمت بيناء مقاييس الدافعية نحو التعلم في المواد التعليمية بصفة عامة والدافعية نحو تطلم الرياضيات بصفة خاصة وقد روعى عند صياغة عبارات المقياس ما يلي :- أن تكون العبارات سليمة لغويًا وسهلة وواضحة ومفهومة للتلاميذ ،وأن تكون متنوعة وممثلة

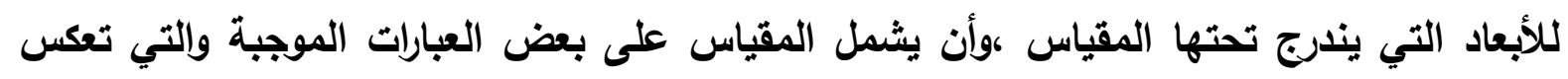

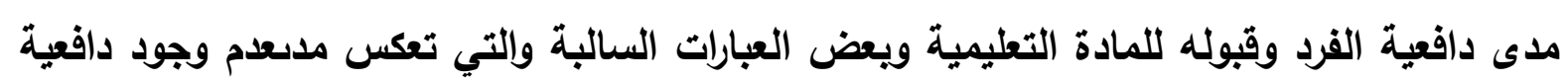




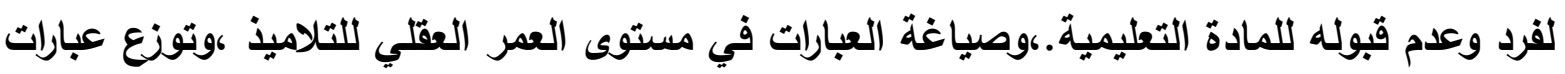
المقياس عشوائيًا.

•صياغة تعلبمات المقباس :. قامت الباحثة بإعداد التعليمات الخاصة بالمقياس بحيث تضمنت البيانات الشخصية للتلميذ واللهدف من المقياس وطريقة الإجابة عنه وروعي أن تكون العبارات سهلة وواضحة وموجزة ويعيدة عن الغموض وق تضمنت الأتي:. توضيح الهدف من المقياس ،ووصف موجز للمقياس وعدد عباراته،والتنبيه بوضع علامة واحدة فقط أمام كل عبارة ،والتتبيه بعدم وجود عبارات صحيحة وعبارت خاطئة لأى عبارة من عبارات المقياس ،والتنبيه بالاجابة على كل عبارات المقياس دون ترك أى عبارة . •الصورة الأولية للمقباس :. بعد مراعاة أسس صياغة عبارات المقياس تم وضع الصورة الأولية للمقياس والتي تكونت من (؟ ؛ ) عبارة موزعة على الأبعاد الثلاثة المكونة للمقياس . •التجرية الاستطلاعية للمقياس وذلك لتحديد :.

أ. زمن المقياس :. تم حساب زمن المقياس أثناء تطبيقه الاستطلاعي بحساب متوسط الزمن التجريبي للمقياس وذلك برصد زمن إجابة كل طالب على المقياس ثم حساب المتوسط الحسابي الأي استغرقه تلاميذ العينة واتضح أن الزمن المناسب للمقياس هو ( • ع ) دقيقة ب ـ ثبات المقياس :. نظرا لطبيعة المقياس وحجم العينة ونتيجة لإجراء التطبيق بشكل قبلي ويعدي على عينة البحث تم حساب معامل ثبات المقياس باستخدام معامل ألفا كرونباخ وكاتت قيمته ( . ع 9, . ) وهو معامل ثبات مرتفع مما يال على ثبات المقياس . ج ـ صدق المقبِاس :.وذلك من خلال عرضه على بعض السادة المحكمين في المناهج وطرق التدريس وعلم النفس وذلك للتعرف على آرائهم في المقياس من حيث :. صياغة سلامة عباراته ومناسبتها لتلاميذ الصف الخامس الابتدائي بطيئي التعلم ،وشمول العبارات للأبعاد المكونة للمقياس ،وايجابية وسلبية عبارات المقياس والتعديل في ضوء أرائهم. دـ الصورة النهائبة للمقياس بعد تحليد زمن المقياس وحساب معاملى الصدق والثبات وإجراء التعديلات على محتوى المقياس في ضوء آراء المحكمين أصبح المقياس في صورته التهائية معدًا للاستخدام. وحيث إن مقياس الدافعية في صورته النهائية تكون من (7 (؟) مفردة بطريقة ليكارت فإن النهاية

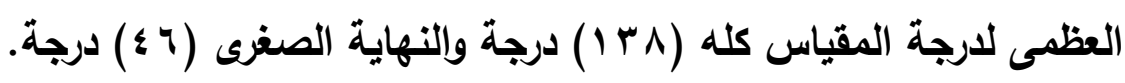

\section{هو}

اتبعت الباحثة الخطوات التبالية ثلعبد التصميم التجريبي :. استخدمت الباحثة التصميم القبلي / البعدي باستخدام مجموعتين متكافئتين إحدامهما ضابطة والأخرى تجريبية 


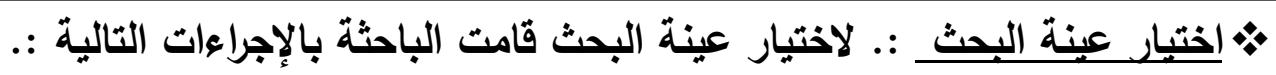
ا.تطبيق اختبار الذكاء الجماعي : تم تطبيق اختبار الذكاء المصور لأحمد ذكي صالح وذلك بهدف لته

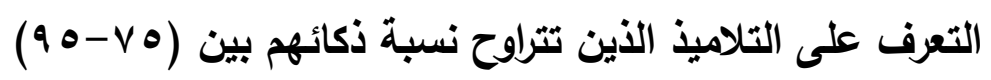

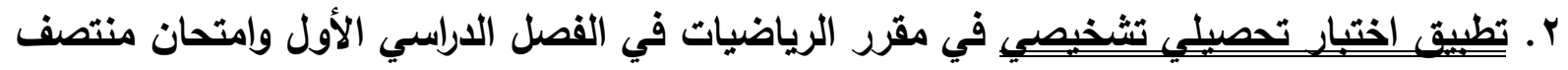

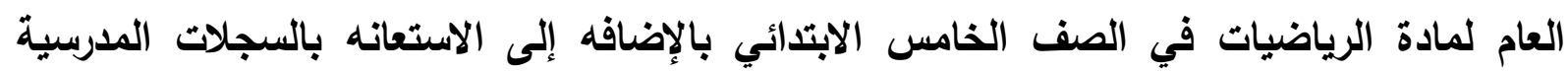

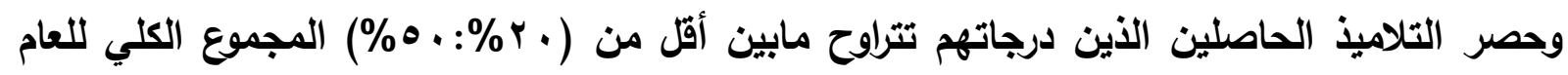

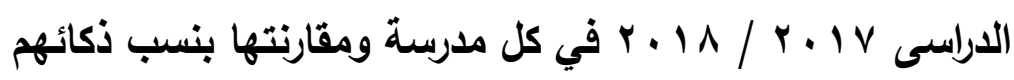

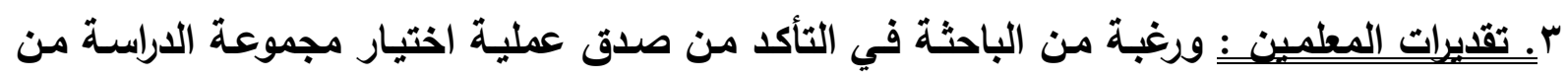

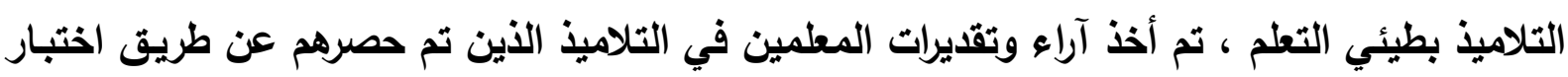

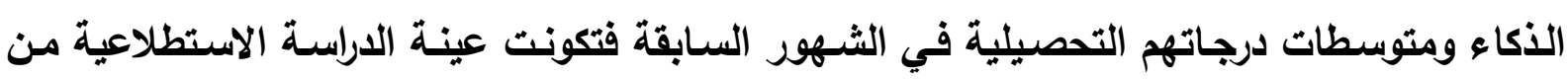

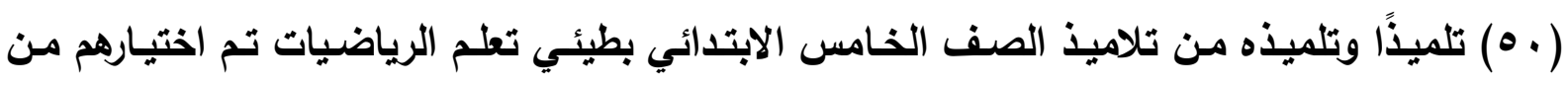

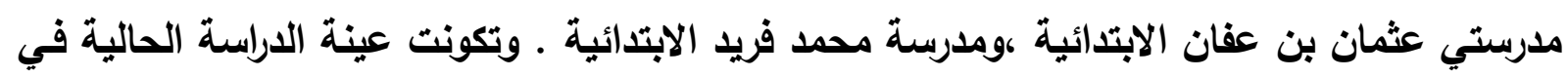

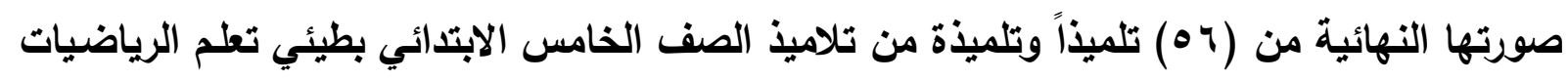
من مدرستى الثهيا السفطي، وعقبة بن نافع الابتدائية .

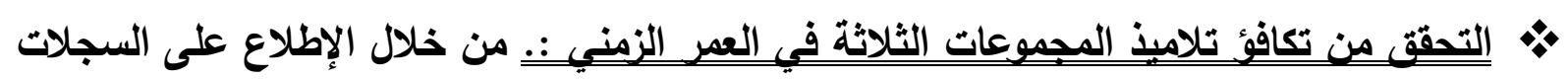

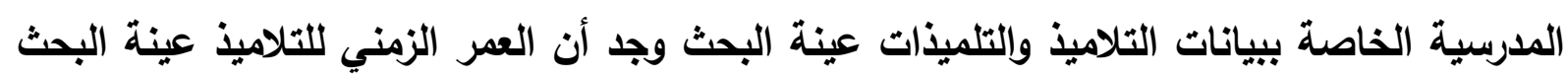
يتراوح بين ( • 1- 11) سنة لذلك فهم متقاريون في العمر. • التحقق من تكافؤ تلامبذ المجموعات في المستوى الاجتماعي والاقتصادي :حيث أن تلاميذ وتلميذات عينة البحث تم اختيارهم من مدارس قريبة من بعضها البعض في المكان وتقع في محافظة واحدة مما يقلل الفروق بين التلاميذ عينة البحث . •التحقق من تكافؤ تلامبذ المجموعات في اختبار التفكير الرياضي:. تم تطبيق اختبار التفكير الرياضي على مجموعتى البحث قبليًا ويحساب الفروق بين متوسطى درجاتهم في اختبار التفكير الرياضي وهذا

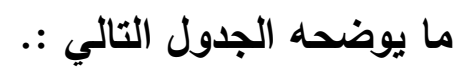
جدول (1) دلالة الفروق بين درجات مجموعتى البحث في التطبيق القبلي لاختبار التفكير الرياضي

\begin{tabular}{|c|c|c|c|c|c|}
\hline الدلالة & قيمة (ت) & الانحراف المعياري & المتوسط & العدد & المجموعة \\
\hline \multirow[t]{2}{*}{ غير دالة } & \multirow[t]{2}{*}{1,0} &,$\wedge \bullet \varepsilon$ & $1 \leq, V 1$ & $r \wedge$ & الضابطة \\
\hline & & $1, \cdot 1$ & $1 \mu, V_{0}$ & $r \wedge$ & التجريبية \\
\hline
\end{tabular}


•التحقق من تكافؤ المجموعات في مقياس الدافعية نحو مادة الرياضيات :.تم تطبيق مقياس الدافعية نحو مادة الرياضيات على مجموعتى البحث قبليًا ويحساب الفروق بين متوسطى درجاتهم في مقياس الدافعية نحو مادة الرياضيات وهذا ما يوضحه الجدول التالي:.

جدول ( r ) دلالة الفروق بين درجات مجموعتى البحث في التطبيق القبلي لمقياس الدافعية

\begin{tabular}{|c|c|c|c|c|c|}
\hline الالالة & قيمة (ت) & الانحراف المعياري & المتوسط & العدد & المجموعة \\
\hline \multirow[t]{2}{*}{ غير دالة } & \multirow[t]{2}{*}{$\cdot, \mathrm{VV}$} & 1,99 & $v_{1}, r_{1}$ & $r \wedge$ & الضابطة \\
\hline & & $T, \cdot V$ & VY,I & YN & التجريبية \\
\hline
\end{tabular}

ويتضح من الجدوليين السابقين عدم وجود فروق ذات دلالة احصائية عند مستوى (ه . , •) بين متوسطى درجات تلاميذ المجموعة الضابطة والتجريبية في التطبيق القبلي للاختبار التحصيلي وإختبار التفكير الرياضي مما يثير إلى تكافؤ المجموعتين في الاختبارين .

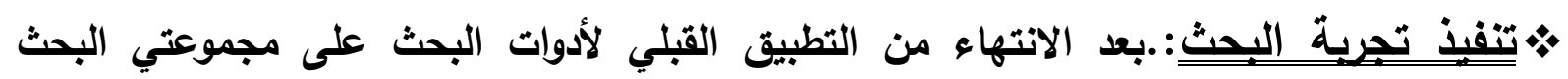
وتحقيق التكافؤ بينهما بدأت الباحثة في تنفيذ التحرية في النصف الثاني من العام الاراسي

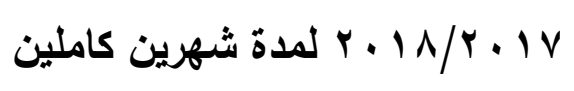
• التطبيق البعدي لأدوات البحث :.بعد الانتهاء من تدريس وحلتى "القياس"، "التحويلات الهندسية " تم تطبيق الاختبار التحيلي، التفكير الرياضي في على تلاميذ مجموعتى البحث، وذلك

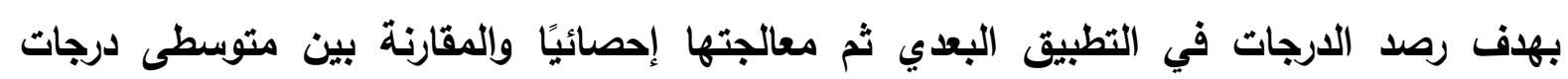
المجموعتين في الاختبارين تمهيدًا لمناقثة تلك النتائج إحصائيًا وتفسيرها واختبار صحة الفروض

\section{* عرض النتائج ومناقشتها وتفسيرها}

فيما يلي عرض لأهم النتائج التي تم التوصل إليها للإجابة على أسئلة البحث والتحقق من صحة فرضه:. أولا:. اختبار صحة الفرض الأول "يوجد فرق ذو دلالة احصائية (ل 2 ه ه., ·) بين متوسطى تلاميذ

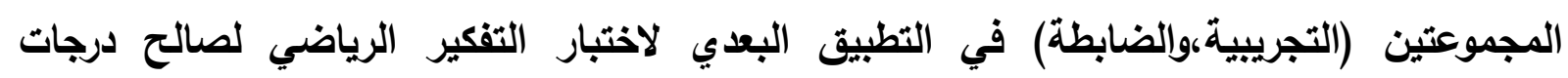

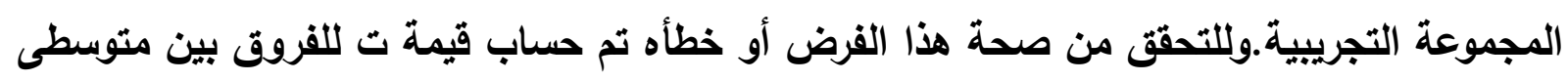

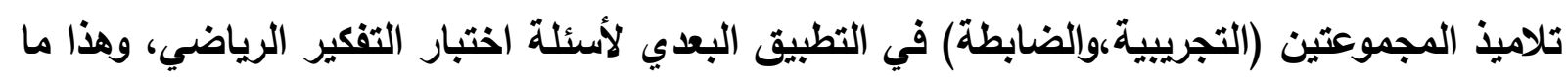
يوضحه الجدول التالي :. 
(فاعلية برنامج قائم على النموذج البنائي التكاملي باستخدام الوسائط المتعددة التفاعلية في تنمية التفكير الرياضي والدافعية نحو تعلم

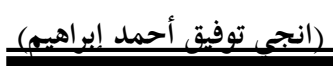
اليياضبات لدى التلامبذ بطيئي التعلم بالمرحلة الابتدائية)

جدول(ب) دلالة الفروق بين متوسط درجات المجموعتين في التطبيق البعدي لاختبار التفكير الرياضي

\begin{tabular}{|c|c|c|c|c|c|c|}
\hline الدلالة & قيمة ت & الانحراف المعياري & المتوسط & 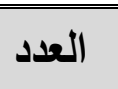 & المجموعة & المهارة \\
\hline \multirow{2}{*}{ دالة } & \multirow[t]{2}{*}{ |r,r| } & 0 & 1,1 & r^ & الضابطة & \multirow[t]{2}{*}{ التعميم } \\
\hline & &, 0.9 & $r, 0$ & $r \wedge$ & التجريبية & \\
\hline \multirow[t]{2}{*}{ دالة } & \multirow[t]{2}{*}{$|\varepsilon, V|$} & 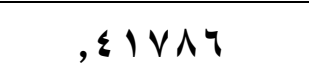 & $\varepsilon, \vee q$ & rA & الضابطة & \multirow[t]{2}{*}{ الاستقراء } \\
\hline & & " & $\mathrm{V}, \mathrm{s}$ & $r \wedge$ & التجريبية & \\
\hline \multirow[t]{2}{*}{ دالة } & \multirow[t]{2}{*}{$r r, \varepsilon \varepsilon$} & $1, \ldots 91$ & $r, \cdot \varepsilon$ & rA & الضابطة & \multirow[t]{2}{*}{ الاستنتاج } \\
\hline & &,$\vee \backslash \wedge \varepsilon$. & q & rA & التجريبية & \\
\hline \multirow[t]{2}{*}{ دالة } & \multirow[t]{2}{*}{ Ir, E } & , АY & צr, & $r \wedge$ & الضابطة & \multirow{2}{*}{ التعبيز } \\
\hline & & 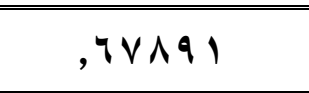 & $7, \ldots$ & $r \wedge$ & التجريبية & \\
\hline \multirow[t]{2}{*}{ دالة } & \multirow[t]{2}{*}{$1 \leq, \varepsilon 7$} & , VYAYr & $r, v q$ & $r \wedge$ & الضابطة & \multirow{2}{*}{ التصور } \\
\hline & &, 011 & $0,0 Y$ & $r \wedge$ & التجريبية & \\
\hline \multirow[t]{2}{*}{ دالة } & \multirow[t]{2}{*}{$1 v, 09$} & , rVA & 1,94 & rA & الضابطة & \multirow{2}{*}{ إدراك } \\
\hline & &, $7 \ldots$ & $\varepsilon, Y q$ & rA & التجريبية & \\
\hline \multirow[t]{2}{*}{ دالة } & \multirow[t]{2}{*}{ rq, r } & o & r, II & $r \wedge$ & الضابطة & \multirow{2}{*}{ المنطق } \\
\hline & & , \& $₹ q$ & $0, \varepsilon$ & $r \wedge$ & التجريبية & \\
\hline \multirow[t]{2}{*}{ دالة } & \multirow[t]{2}{*}{$\varepsilon \Psi, \varepsilon \varepsilon$} &, 907 & $\mid \wedge, 11$ & YA & الضابطة & \multirow[t]{2}{*}{ الاختبار ككل } \\
\hline & & I,vor & P $r, 0$. & $r \wedge$ & التجريبية & \\
\hline
\end{tabular}

يتضح من الجدول السابق أن قيمة " ت " = ع ؟.بـ للاختبار ككل وهى دالة عند مستوى ( ه ., •) ويهذا فقد تحققت صحة الفرض الأول كما قامت الباحثة بحساب (†⿰ ) كمؤثر على الفاعلية وكذلك التأكد من أن الفروق التي ظهرت بين درجات تلاميذ المجموعتين ليست نتيجة الصدفة ، وياستخدام "ت " ، ودرجات الحريةة تم حساب (آ† ) وتوصل البحث للنتائج الموضحة بالجدول التالي :.. جدول (ع) حجم تأثير البرنامج على التحصيل الاراسي

\begin{tabular}{|c|c|c|c|c|}
\hline حجم التأثير & $\eta$ & ث & المتغير التابع & المتغير المستقل \\
\hline كبيز &., $9 V$ & $\varepsilon \Psi, \varepsilon \varepsilon$ & التقكير الرياضي & البرنامجج \\
\hline
\end{tabular}

ثم من خلال بيانات الجدول السابق يتضح أن قيمة (2ض) لقوة العلاقة بين المتغير المستقل (التدريس بالبرنامج) والمتغير التابع (التفكير الرياضي) = 9V , ، ولألك فان قيمة حجم التأثير كبير مما يعد مؤشرًا على فاعلية التدريس بالنموذج البنائي التكاملي في تتمية التفكير الرياضي. 


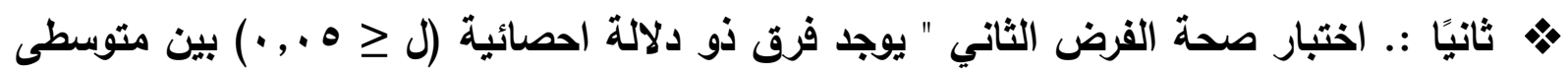
تلاميذ المجموعتين (التجريبية،والضابطة) في التطبيق البعدي لمقياس الدافعية لصالح درجات المجموعة التجريبية ـ وللتحقق من صحة هذا الفرض أو خطأه تم حساب قيمة ت للفروق بين متوسطى تلاميذ المجموعتين (التجريبية ،والضابطة) في التطبيق البعدي لمقياس الدافعية نحو تعلم الرياضيات ، وهذا مايوضحه الجدول التالي :.

جدول(ه) دلالة الفروق بين متوسط درجات المجموعتين في التطبيق البعديلمقياس الدافعية

\begin{tabular}{|c|c|c|c|c|c|c|}
\hline الدلالة & قيمة ت & الانحراف & المتوسط & العدد & المجموعة & البعد \\
\hline \multirow[t]{2}{*}{ دالة } & \multirow[t]{2}{*}{$1 \leq, 11$} & 1.97 & $r \leq .9 r$ & $r \wedge$ & الضابطة & \multirow{2}{*}{ الاهتمام والاستمتاع } \\
\hline & & r.q & $4 . .41$ & $r \wedge$ & التجريبية & \\
\hline \multirow[t]{2}{*}{ دالة ل } & \multirow[t]{2}{*}{ Ir,. $\varepsilon$} & 1.87 & rr.rq & $r \wedge$ & |الضابطة & \multirow{2}{*}{ السادة الرياضيات" والمثابرة لتعلم } \\
\hline & & $\varepsilon .+1$ & TY.ru & $r \wedge$ & التجريبية & \\
\hline \multirow[t]{2}{*}{ دالة ل } & \multirow[t]{2}{*}{$10, r$} & $1 . V r$ & $r \leq .11$ & $r \wedge$ & الضابطة & \multirow{2}{*}{ الحوار والمناقشة } \\
\hline & & $r . \leqslant q$ & ro.ro & $r \wedge$ & التجريبية & \\
\hline \multirow[t]{2}{*}{ دالة ل } & \multirow[t]{2}{*}{ IA.Vo } & $r .9 .79 r$ & VI.rr & $r \wedge$ & |لضابطة & \multirow[t]{2}{*}{ مقياس الدافعية ككل } \\
\hline & & $0 . \varepsilon \cdot Y 11$ & $1 . \varepsilon . Y^{9}$ & $r \wedge$ & التجريبية & \\
\hline
\end{tabular}

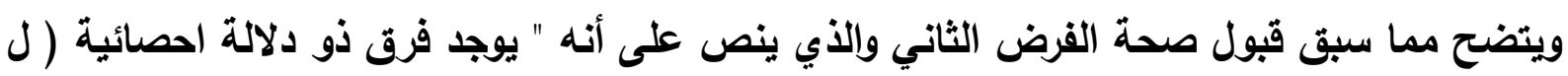

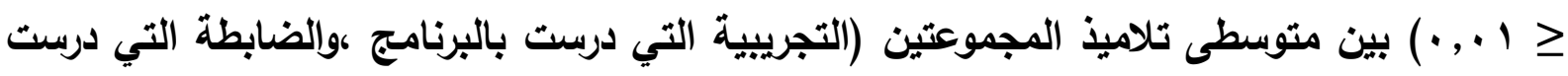

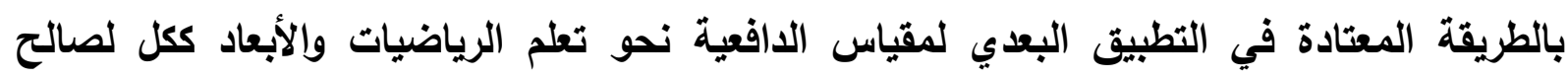

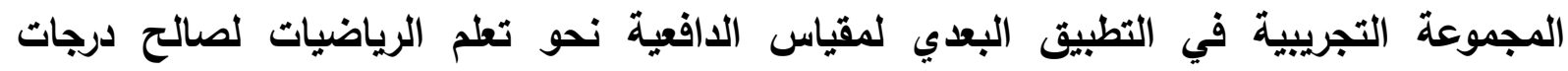

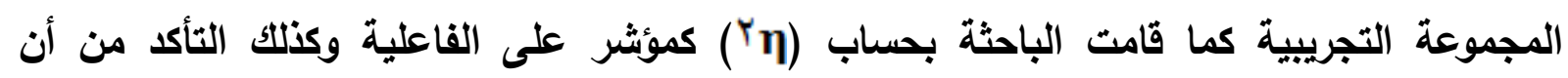
الفروق التي ظهرت بين درجات تلاميذ المجموعتين ليست نتيجة الصدفة،وياستخدام"ت"،ودرجات

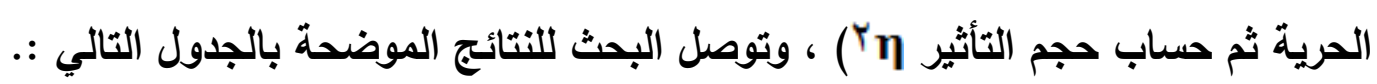

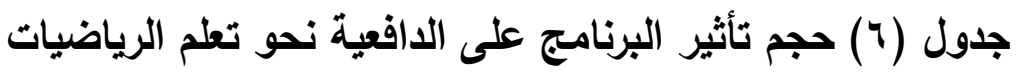

\begin{tabular}{|c|c|c|c|c|}
\hline حجم التأثير & ${ }^{\top} \eta$ & ت & المتغير التابع & المتغير المستقل \\
\hline كبير & $\cdot, \wedge \vee$ & $1 \wedge . v_{0}$ & الدافعية & البرنامج \\
\hline
\end{tabular}


خ من خلال بيانات الجدول السابق يتضح أن قيمة (2ض) لقوة العلاقة بين المتغير المستقل (التدريس بالبرنامج) والمتغير التابع (الدافعية نحو تعلم الرياضيات) = AV , . ملألك فان قيمة حجم التأثثر كبير مما يعد مؤثرًا على فعالية التدريس بالبرنامج في تنمية الدافعية نحو تعلم الرياضيات.

\section{أولًا :. تفسير نتائج البحث المرتبطة بالتفكير الرياضي} 1.أوضحت نتائج الفرض البحثي الأول يوجد فرق ذو دلائة إحصائية (ل>ه ....) بين متوسطى درجات تلاميذ مجموعات مجموعتى البحث (الضابطة التى درست بالطريقة المعتادة ، التجريبية (ץ) التي درست بالنموذج البنائي التكاملي باستخدام الوسائط المتعددة التفاعلية) من التلاميذ بطيئي التطلم في التطبيق البعدي لاختبار مهارات التفكير الرياضي لصالح المجموعة التجريبية . مما يشير إلى فعالية استخدام النموذج البنائي التكاملي باستخدام الوسائط المتعددة التفاعلية في تنمية

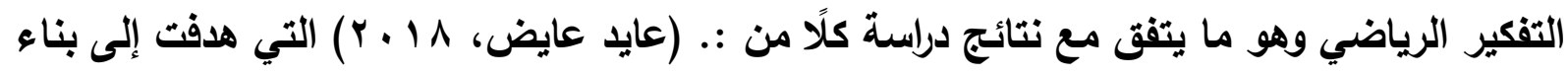

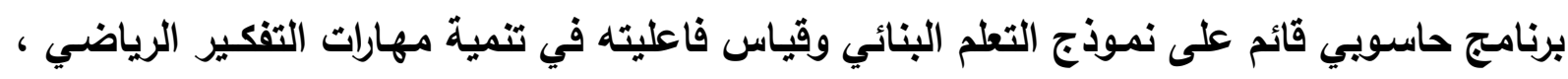

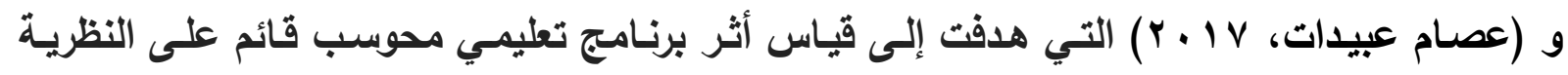

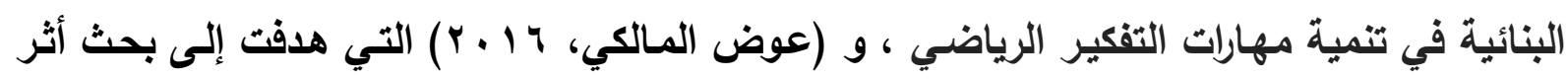

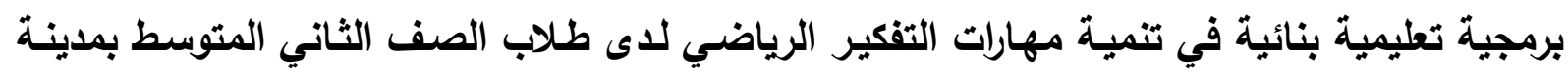
الطائف ،وفونكيرت (Fonkert,2012) التي توصلت إلى فعالية التفاعل بين الطالب وإلكمبيوتر والتي لتئي

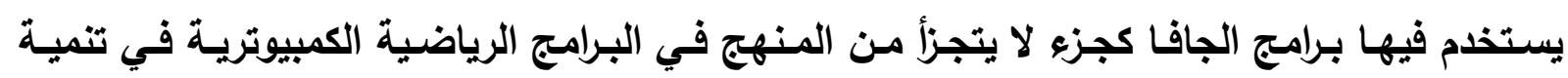

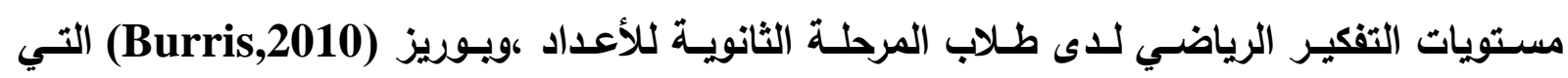

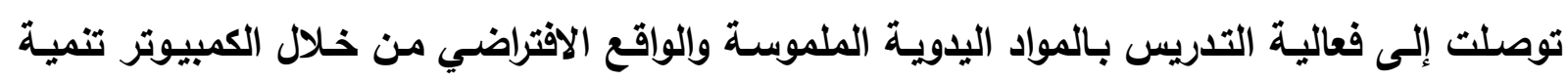

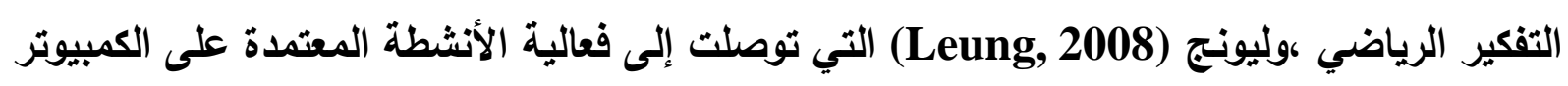

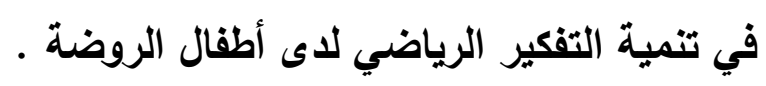

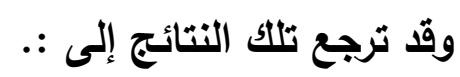
ا ـ إتاحة الأنشطة والتمارين الرياضية المتضمنة في دروس الوحدتين والتي تتطلب التفكير والنشاط العقلي مزيد من الفرص لتنمية مستويات التفكير الرياضي من حيث التمارين والأنشطة التي تعمل على تنمية مهارات التعميم والمنطق الثكلى والاستتتاج والاستقراء. r. التدريس بالبرنامج في جميع مراحله يركز على تنمية مهارات التفكير الرياضي فمن خلال عرض الأمثلة والتمارين والأنثطة وإعطاء أكثر من مثال يمكن من خلالها استنتاج القانون أو القاعدة أو النظرية وإكتثاف العلاقات بينها يمكن من خلالها الخروج بتعميمات جديده سبق دراستها . 
r. إعتماد البرنامج على النموذج البنائي التكاملي والتي تقوم على الريط بين المعلومات السابقة بالمعلومات الجديدة وهذا يلاعم التلاميذ بطيئي التعلم بما يعمله من تنظيم البناء المعرفي لايهر ويالتالي تنمية مهارات الاستقراء والاستتتاج التي تتطلب من التلميذ أن يلاحظ الحالات والأمثلة

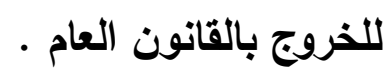

؛. إتاحة الوسائط المتعددة التفاعلية الفرص أمام التلاميذ بطيئي التطلم للتدريب على مهارات التفكير الرياضي بطريقة تراعى الجاذبية والبساطة في عرض المهارات من خلال عرض أمثلة محسوسة

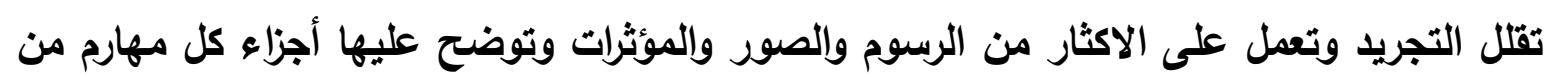

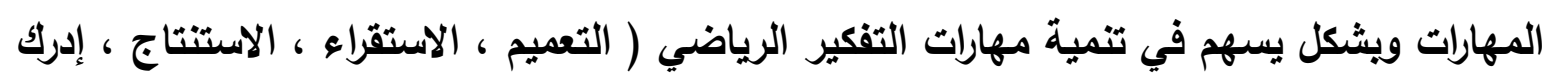
العلاقات ، التصور البصري المكاني ، المنطق الثكلي ،التعبير الرمزي ).

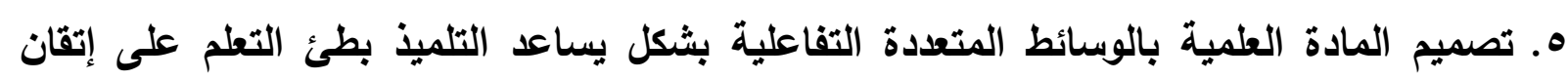
مهارة التعبير بالرموز وذلك عند توضيح الثكل الهنسي برموزه والتسجيل الصوتي للحل وتوضيح

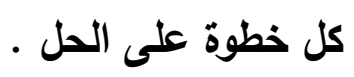
4. إتقان مهارة التصور البصري من خلال رسم الأثكال الهندية وتوضيحها على الثاثثة وكذلك

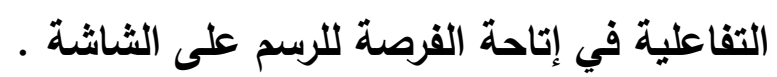
V. إتقان مهارة الاستقراء والاستنتاج من خلال عرض المزيد من الأنثطة التي تتناول عرض مجموعة من الحالات الخاصة بقانون أوقاعدة ما والتي من خلالها نصل إلى الاستنتاج الخاص بها. ثانيًا:. تفسير نتائج البحث المرتبطة بالدافعية نحو تعلم الرياضيات

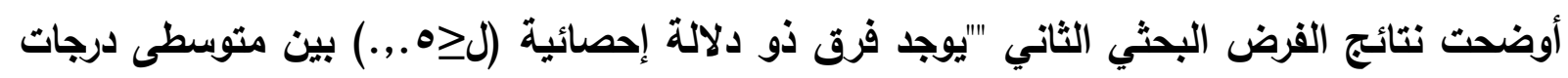

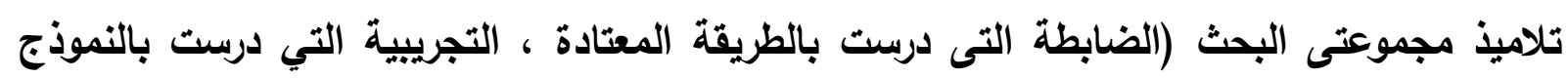

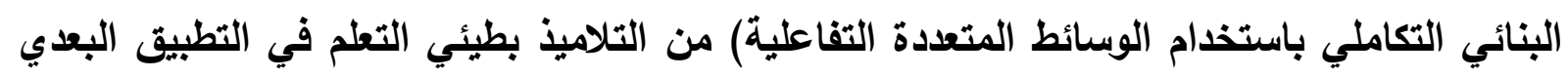

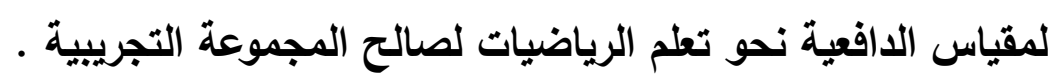

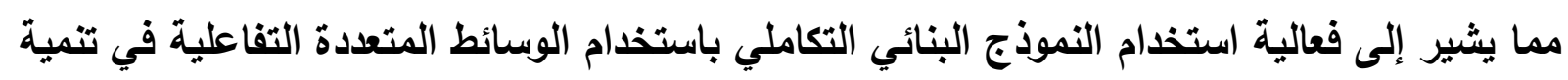

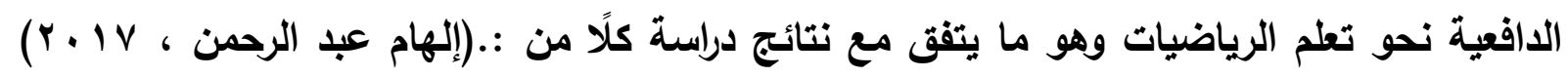

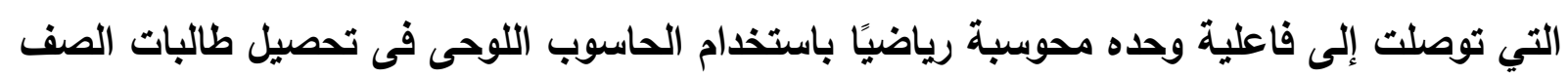

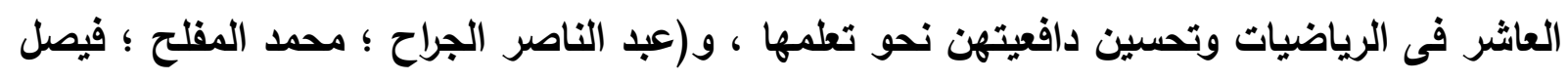

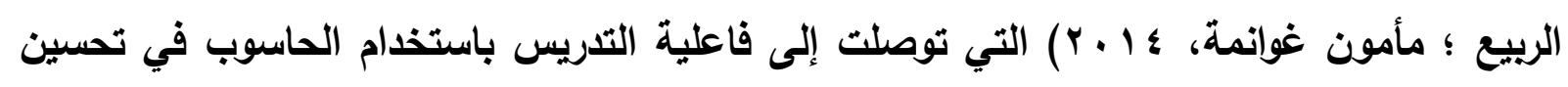

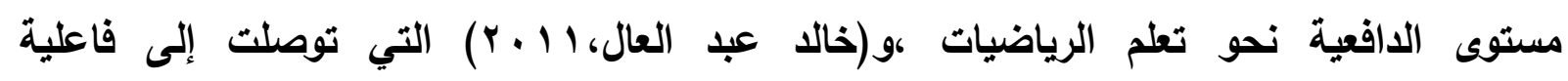


إستراتيجيتي تحكم المتعلم وتحكم البرنامج باستخدام الحاسوب في تنمية الدافعية للإنجاز للتلاميذ

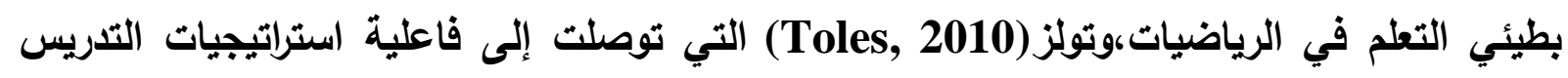

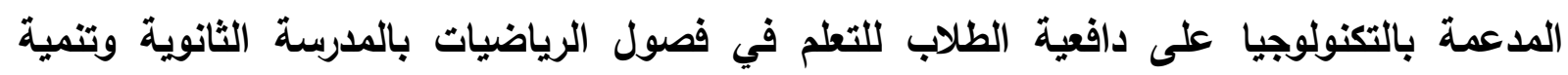
المهارات الرياضية ومهارات حل المشكلات. وقد ترجع تلك النتائج إلى :

ا ـ برامج الوسائط المتعددة التفاعلية التي تقوم على التنوع والتكامل في استخدام المثيرات والمؤثرات الصوتية والحركية والصور والرسوم الثابتة والمتحركة يناسب التلميذ بطيئ التطلم لجذب انتباههم

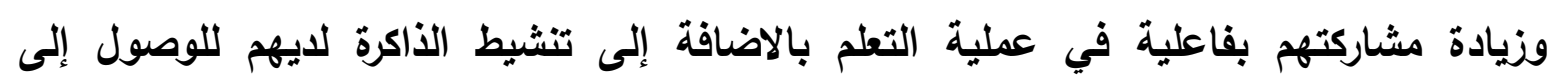
المعلومات الجديدة ذات الصلة بالمعلومات السابقة زاد من شعورهم بالثقة وتقليل الاحباطات النفسية السابقة نتيجة للخبرات التعليمية السيئة وزيادة الاهتمام بما يتناسب مع إمكانياتهم وحاجاتهم وقدراتهم ترتب على ذلك زيادة دافعية التلاميذ نحو دراسة مادة الرياضيات . r. التركيز على فئة التلاميذ بطئ التعلم الذين تم تحديدهم قبل باية تدريس الوحدتين بالبرنامج

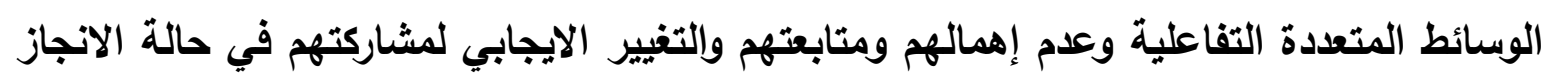
وإلتشجيع لمحاولات أخرى في حالة الاخفاق ومساعلتهم للوصول للهذف يؤدي ذلك إلى زيادة الأفعية لاراسة مادة الرياضيات . r. التنويع في الأنثطة والتمارين ومناقثة التلاميذ في حلها والتعاون وإثارة المنافسة بين المتعلمين للوصول إلى الحل الصحيح تحت إثراف المعلم والتعزيز المستمر إلى المجموعات التي تتوصل إلى الى الحل الصحيح يساعد ذلك على إثباع دوافع المتعلمين وزيادة الثقة بأنفسهم ومشاركتهم في إنى إنى

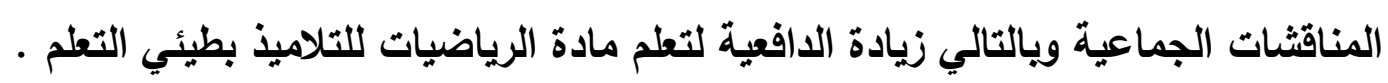

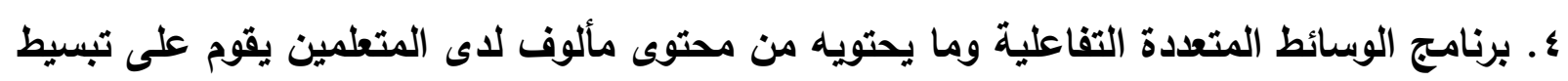
وتوضيح المفاهيم والمعلومات في المحتوى المدرسي وتدعيمه بالأمثلة المحسوسة لتوضيح أفكار الدرس وتثجيع المتعلمين على التساؤل وطرح الأسئلة حول المحتوى التعليمي يزيد من فهم المتعلمين للمحتوى ويالتالي يزيد من ثقة المتعلمين بأنفسهم ويالتالي زيادة الدافعية نحو التعلم . هـ نماذج النظرية البنائية والتي تعمل على تزويد المتعلمين بمتطلبات التعلم القبلية ومساعدته على بلى بلى بله تذكر التعلم السابق للاستفادة منه في التعلم الجديد بالاضافة إلى الوسائط المتعددة التفاعلية والتي 
تمكن المتعلم من السيطرة على البيئة التعليمية بثكل يتيح له حرية التحرك والتحكم في عمليات التعلم تعمل على تعزيز الثقة لاى المتعلمين ويالتالي تزداد الدافعية .

\section{* * *وصيات البمث}

بناءً على ما أسفر عنه البحث نظرياً وتطبيقياً وفي ضوء ما تم التوصل إليه من نتائج ، توصي

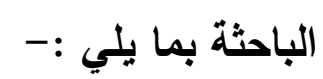

ا. الاهتمام بالتنوع في استخدام الطرق التدريسية والنماذج البنائية والمداخل التدريسية القائمة على استخدام الكمبيوتر وتطبيقاته في الموقف التعليمي لمراعاة الفروق الفردية بين الفئات المختلفة . r. الاهتمام بتنمية مهارات التفكير المختلفة وخاصة التفكير الرياضي ككل ويطيئ التعلم بصفة خاصة لأن ذلك يزيل من ثقتهم بأنفسهم ويقدراتهم الكامنه . r. الاهتمام بتحديد بطيئي تعلم الرياضيات في الفصل والتركيز على مشاركتهم والتفاعل الايجابي داخل الفصل واستخدام التعزيز الايجابي المناسب واستخدام الطرق والمداخل التدريسية التي تجذب انتباههم وتزيد من حماسهم في المشاركة داخل الفصل.

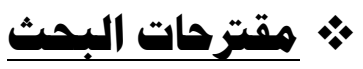

في ضوء ما أسفر البحث من نتائج وما تقدم من توصيات تقترح الباحثة إجراء الدراسات التالية:ا.دراسة فاعلية الوسائط المتعددة التفاعلية في تتمية التحصيل والتفكير الابتكاري لدى فئن التلاميذ المتفوقين بالمرحلة الابتدائية . r.دراسة فاعلية الوسائط المتعددة التفاعلية في تنمية التحصيل والتفكير الرياضي والاتجاه نحو المادة لاى التلاميذ المتأخرين دراسيا ومنخفضي التحصيل لاى تلاميذ المرحلة الابتدائية. r.دراسة مقارنه لفعالية نموذج بايبي البنائي باستخدام الوسائط المتعددة التفاعلية التحصيل والتفكير الرياضي بين التلاميذ بطيئي التعلم وذوي صعويات تعلم الرياضيات لدى تلاميذ المرحلة الابتدائية. 


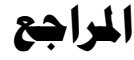

أولا : المراجع العربية

ا. إبراهيم رفعت إبراهيم محمد(ه . . ץ) : فاعلية المدخل البنيوى باستخدام برامج الكمبيوتر متعددة الوسائط في علاج صعويات تعلم الهندة وخفض القلق الهندسي لدي تلاميذ المرحلة الإعدادية،

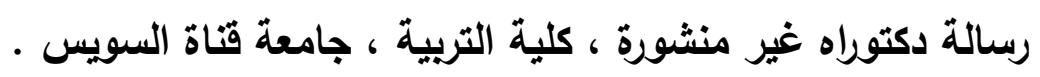

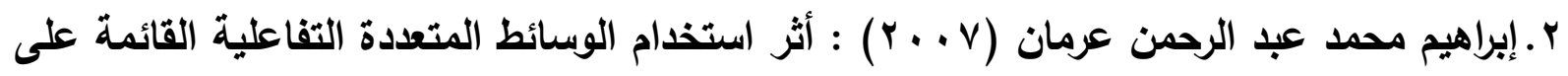
الحاسوب على تحصيل طلبة الدراسات العليا في مقرر استخدام الحاسوب في التربية ، مجلة جامعة التحة القدس المفتوحة للأبحاث والدراسات ، العدد الحادي عشر ـ

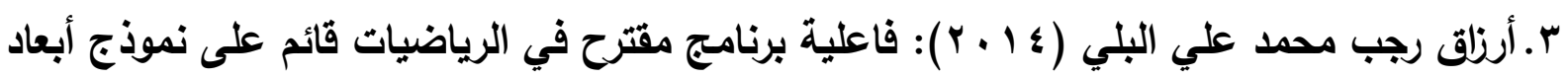

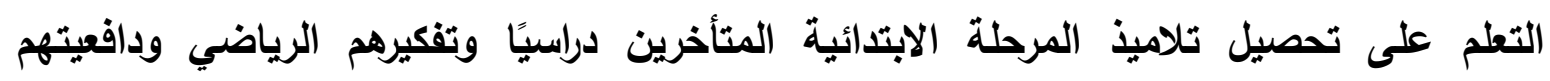

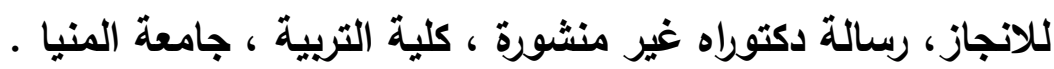

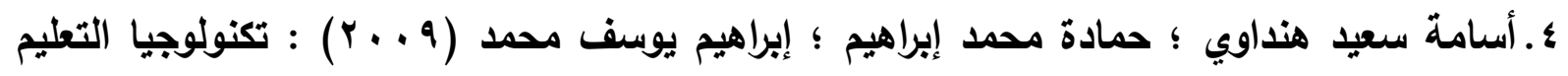
والمستحدثات التكنولوجية ، القاهرة ، عالم الكتب.

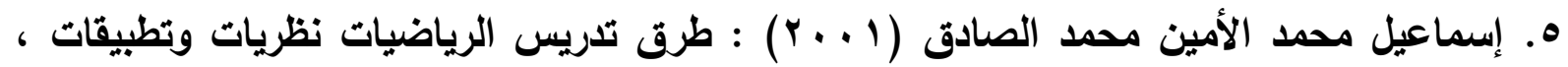
القاهرة ، دار الفكر العربي.

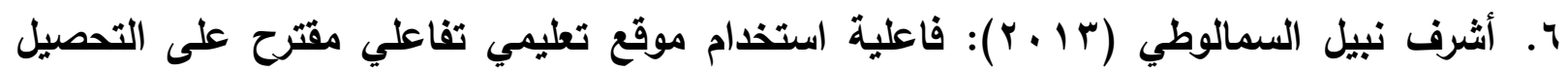

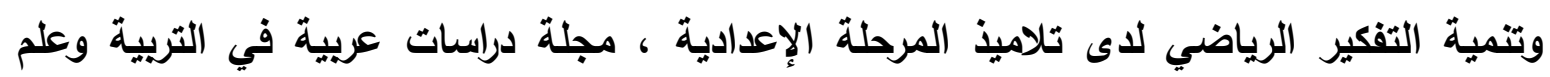

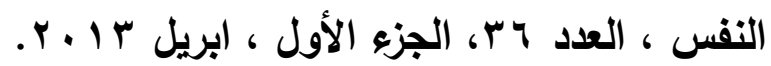

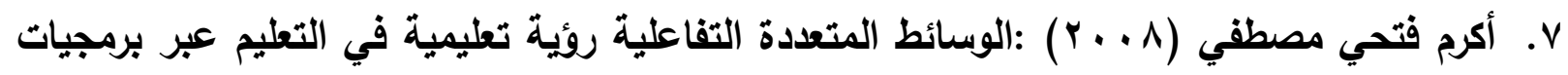

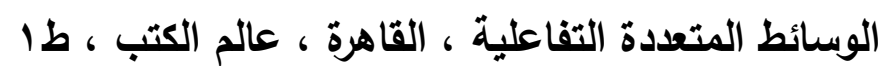

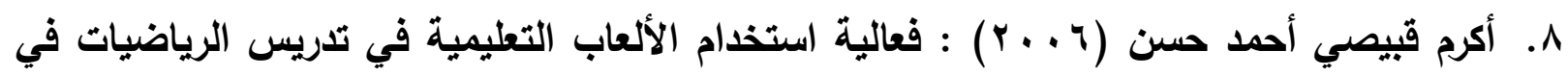

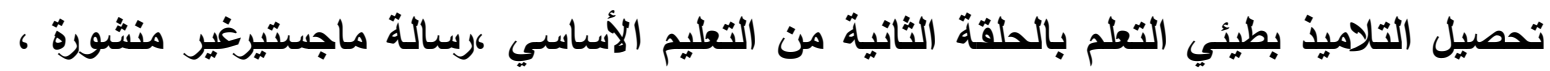
معهز الاراسات التربوية ، جامعة القاهرة.

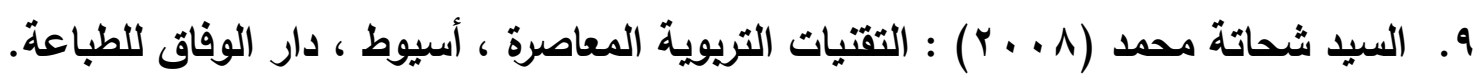




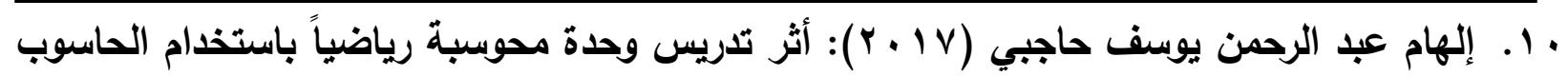

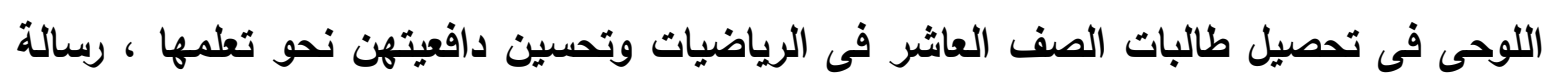

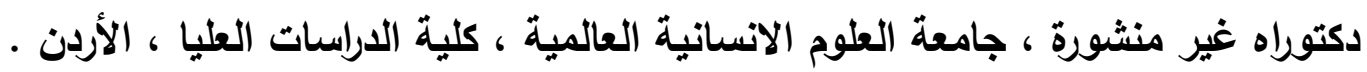

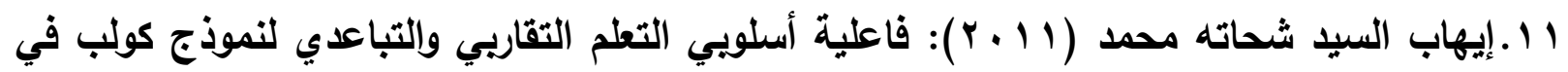
تنمية التحصيل والتفكير الرياضي لتلاميذ الصف الثاني الإعدادي ، مجلة العلوم التريوية ، كلية

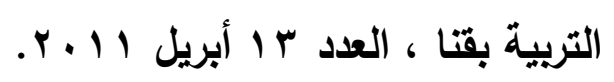

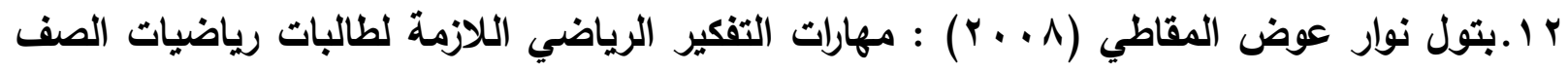

الأول المتوسط، رسالة ماجستير( غير منشورة) ،كلية التربية،جامعة أم القرى ،السعودية.

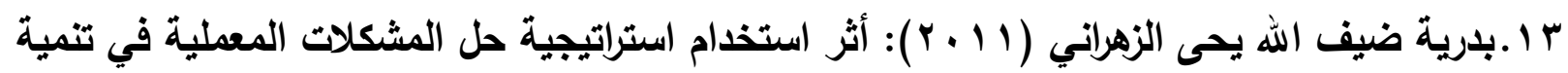
التحصيل والتفكير الهنسي لاى بطيئات التعلم بالصف السادس الابتدائي بمنطقة عسير، مجلة التهل

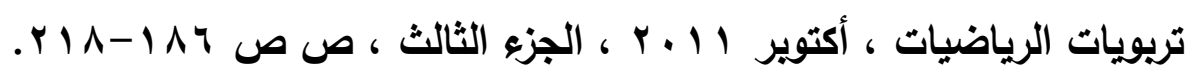

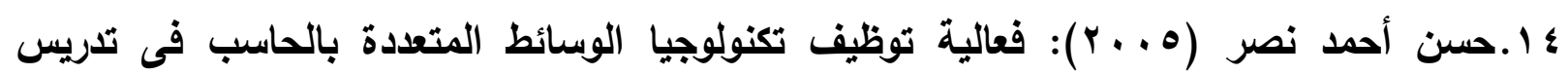

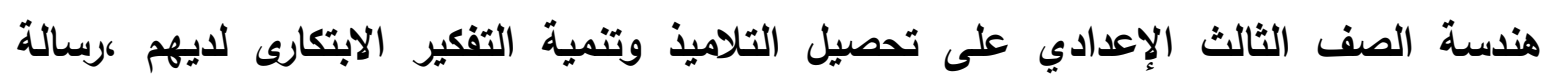
دكتوراه غير منشورة ، كلية التربية بيني سويف ، جامعة القاهرة .

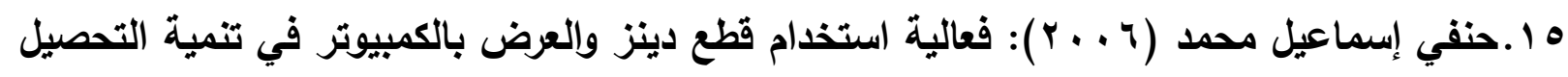
والتفكير الرياضي لدى التلاميذ بطيئي التعلم بالمرحلة الابتدائية،مجلة تريويات الرياضيات، كلية ولية

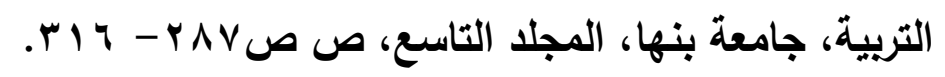

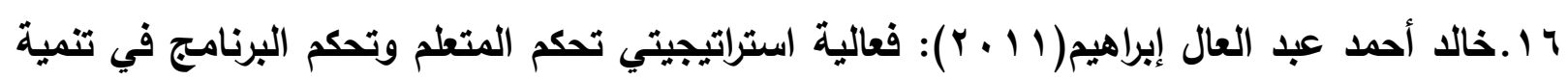

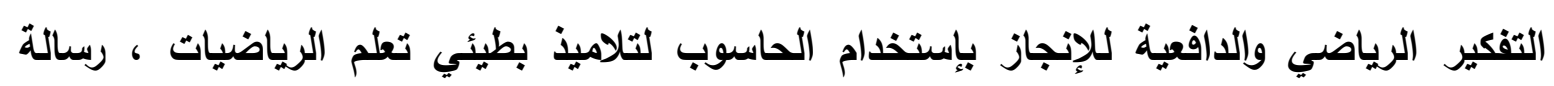

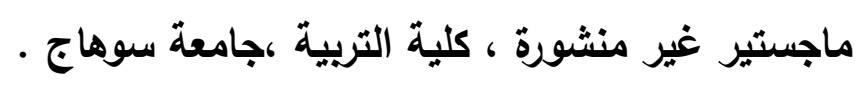

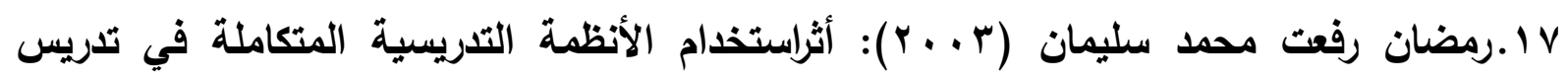

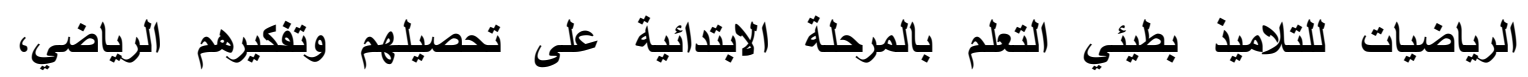
المؤتمرالعلمي الثالث للجمعية المصرية لتربويات الرياضيات(تعليم وتعلم الرياضيات وتنمية الاتئية

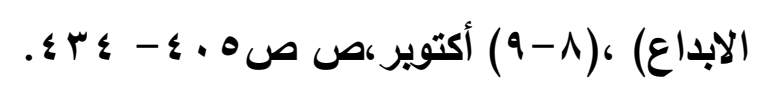

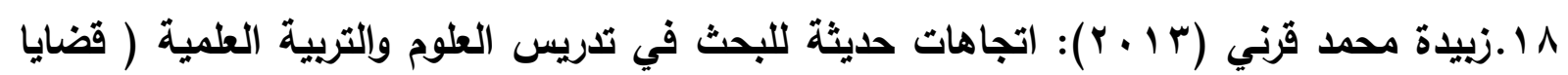

بحثية ورؤى مستقبلية ، المنصورة ، المكتبة العصرية.

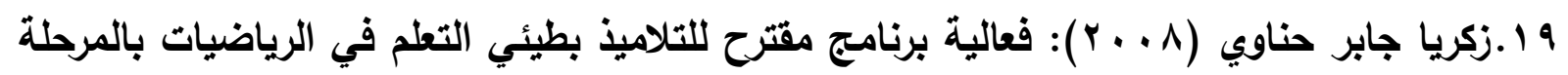

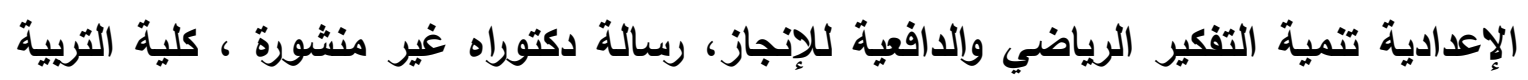
جامعة أسيوط. 


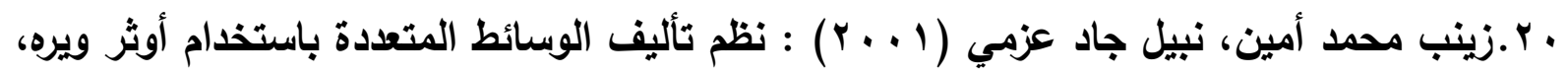
المنيا ، دار الهاى للنشر والتوزيع.

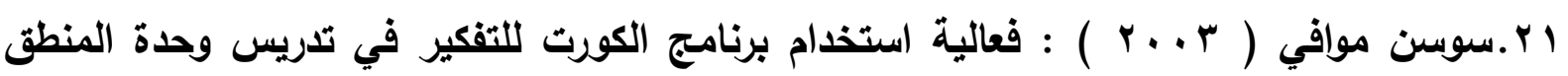

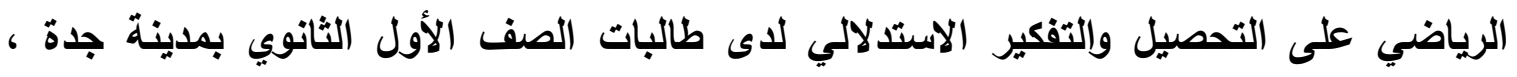
الجمعية المصرية لتريويات الرياضيات، المؤتمر العلمي الثالث، تعليم وتعلم. الرياضيات، دار لارل

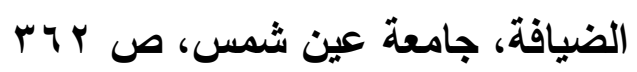

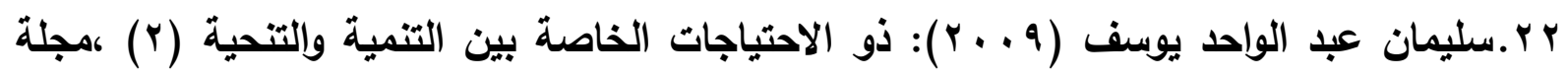

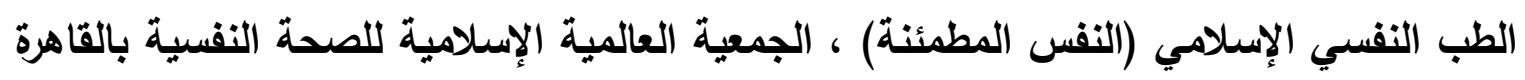

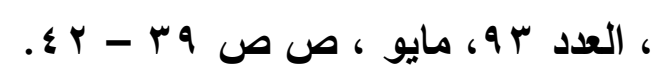

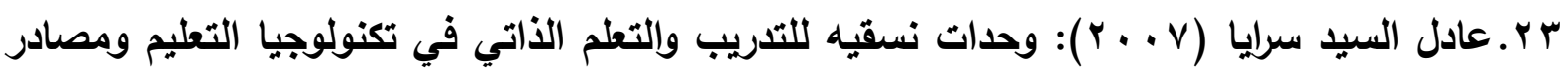
التعلم (مفاهيم نظرية- تطبيقات عملية) ،الجزء الثاني، مكتبة الرشد ،المملكة العربية السعودية.

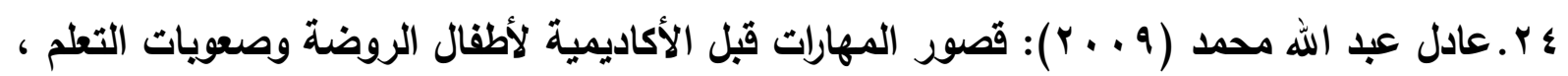

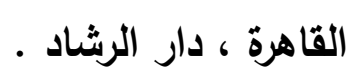

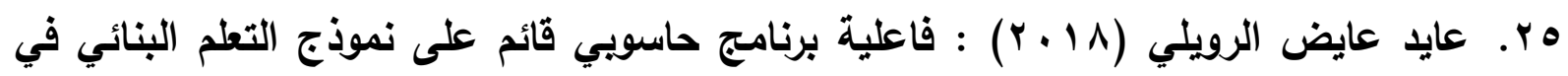

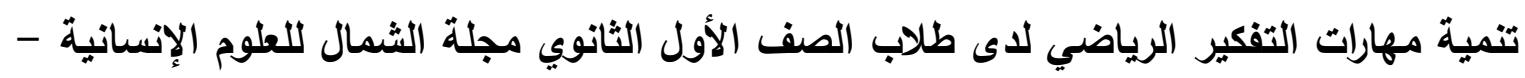

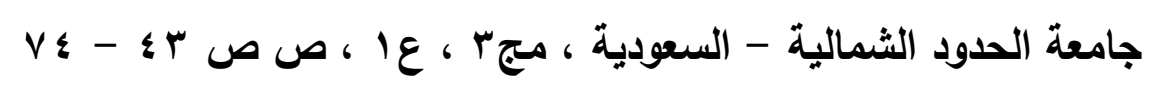

ד.

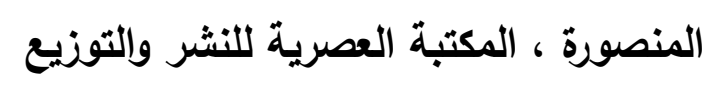

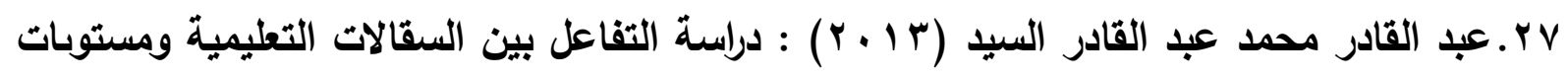

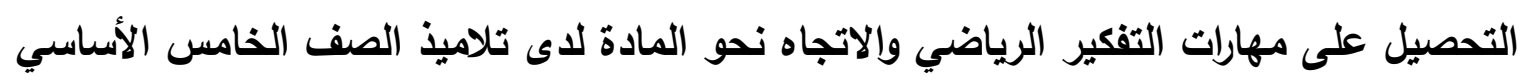

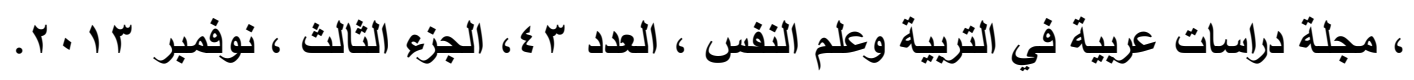

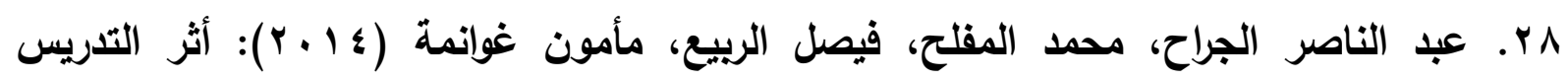
باستخدام برمجية تعليمية في تحسين مستوى دافعية المتعلمين نحو تعلم الرياضيات لاى طلبة الدانة

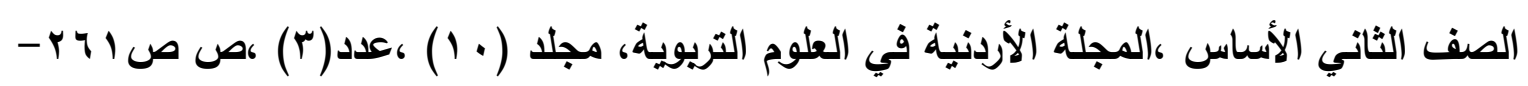
.$r V \varepsilon$

9 Y.عبد الواحد حميد الكبيسي (11 + ب) : أثر استخدام إستراتيجية التدريس التبادلي على التحصيل

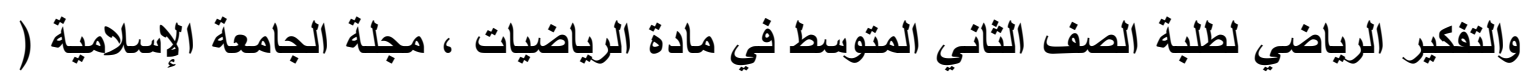

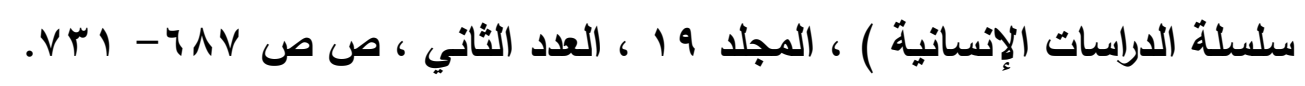




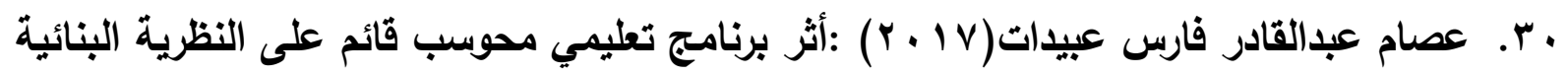

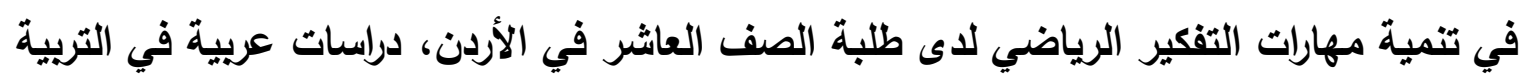

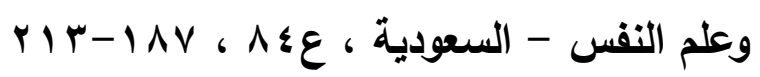

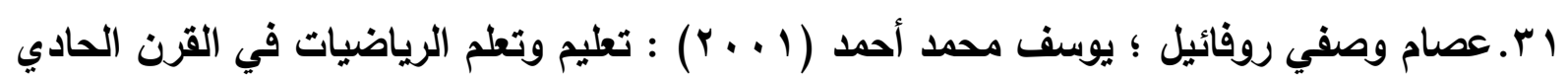
والعشرين، القاهرة، مكتبة الأنجلو المصرية.

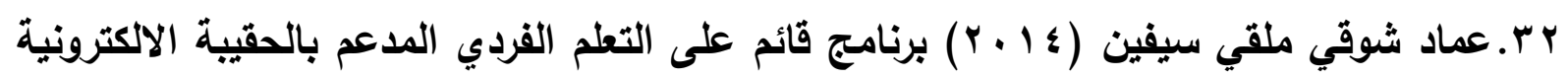

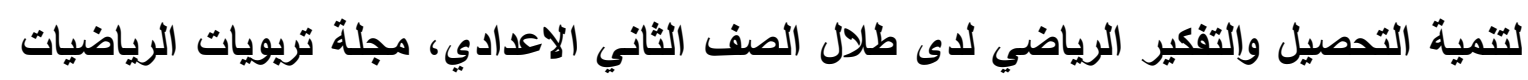

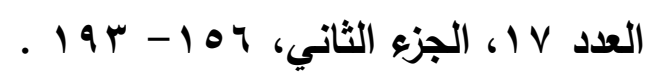

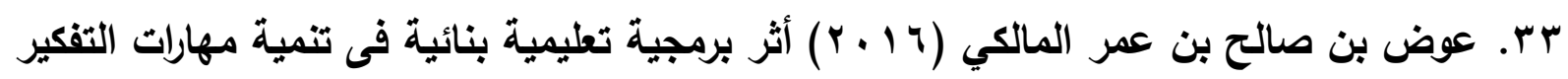

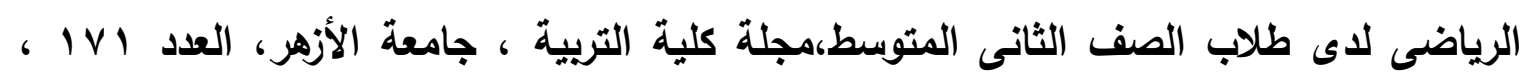

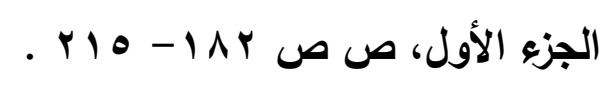

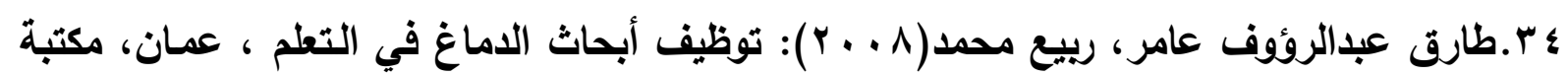
اليازوري العلمية.

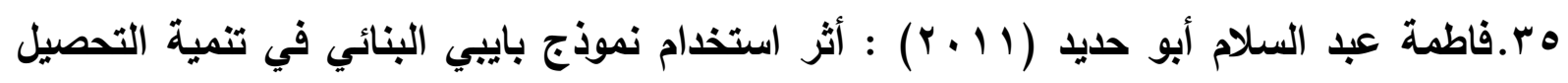

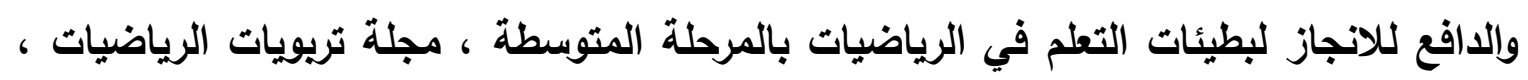

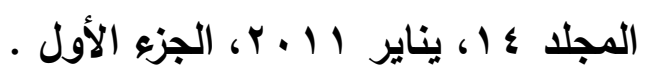

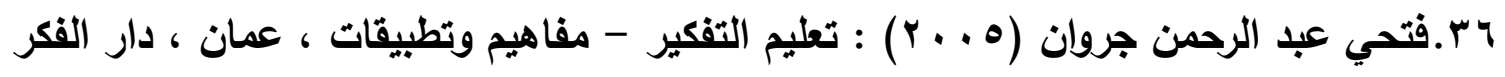

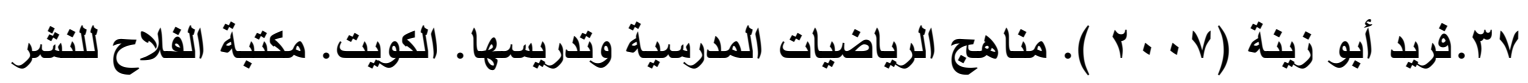

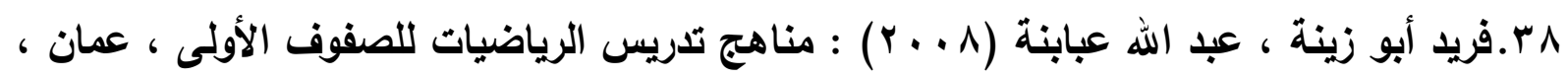

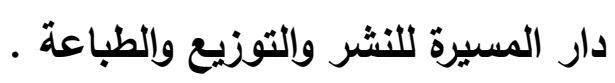

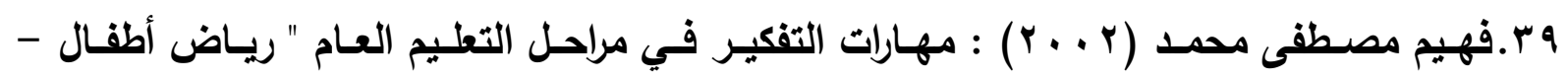

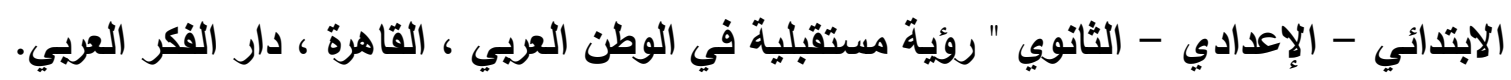

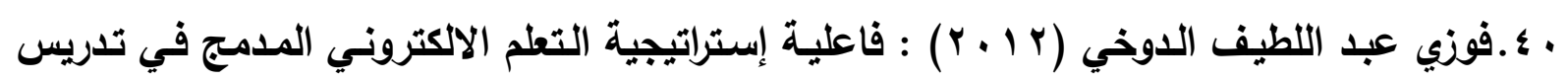

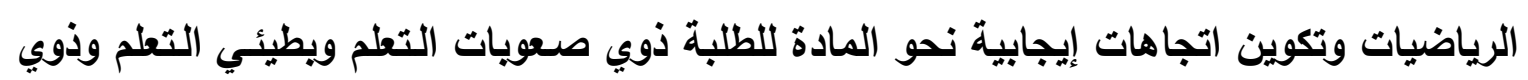

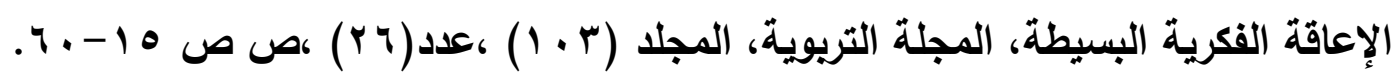

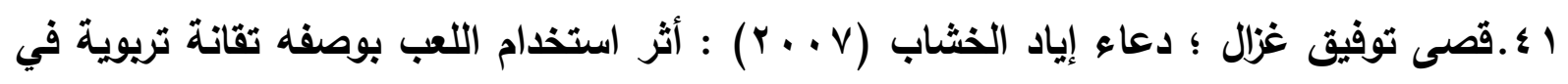

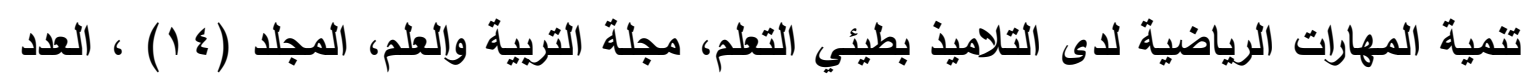

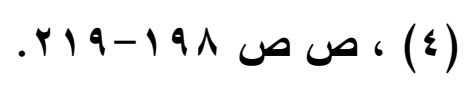

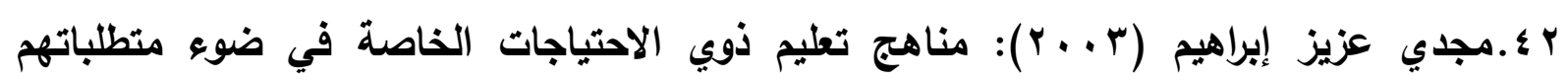
الإنسانية والاجتماعية والمعرفية، القاهزة ، مكتبة الانجلو المصرية. 


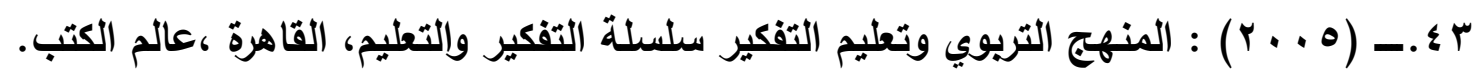

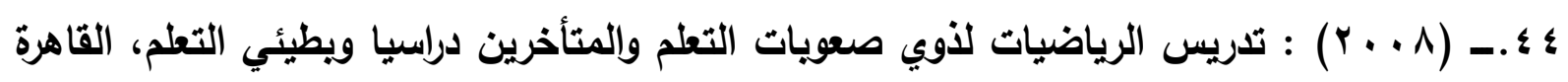

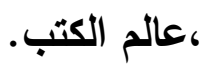
ه ؛... (9 . . ب): التفكير الرياضي وحل المشكلات، سلسلة التفكير والتعليم والتعلم ،القاهرة ،عالم الكتب.

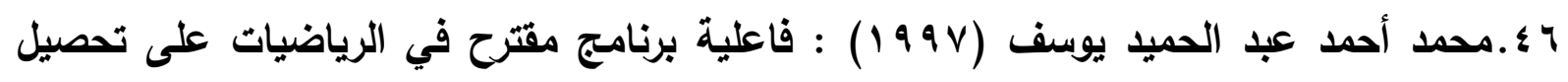

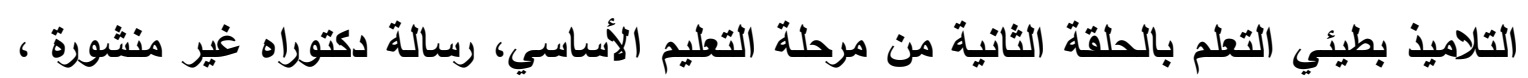
كلية البنات للعلوم والآداب والتربية.

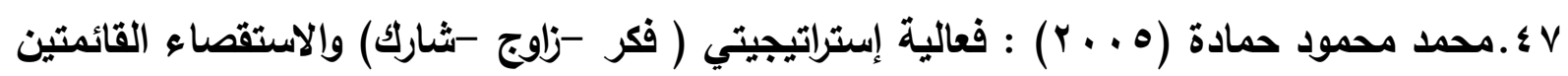

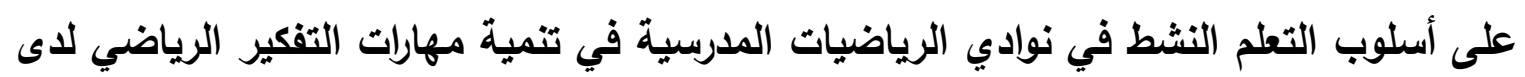

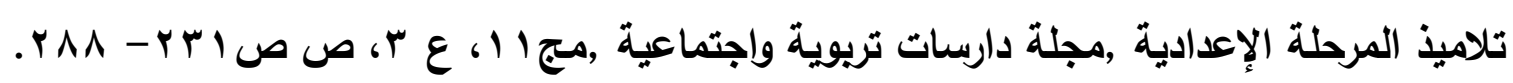

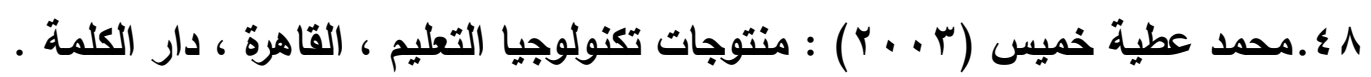

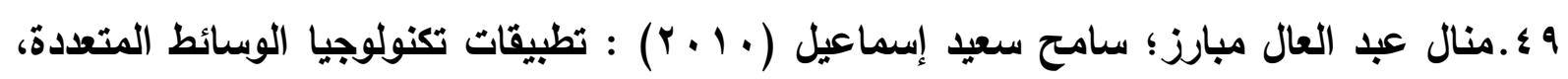

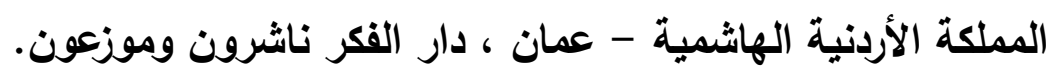

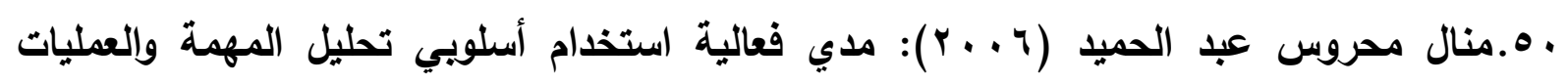
العقلية في حل مشكلات الحساب لاى تلاميذ الصف الرابع بطيئي التعلم- دراسة تجريبية، رسالة

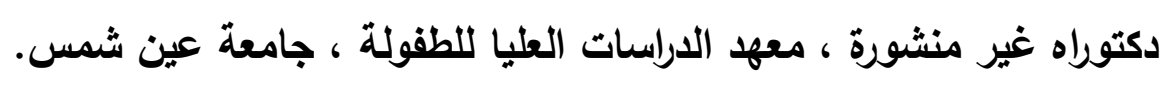

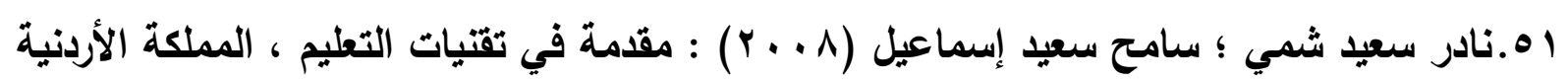

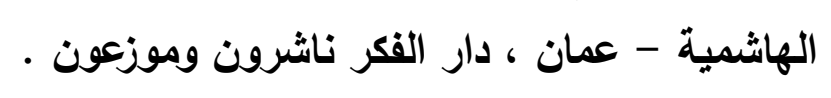

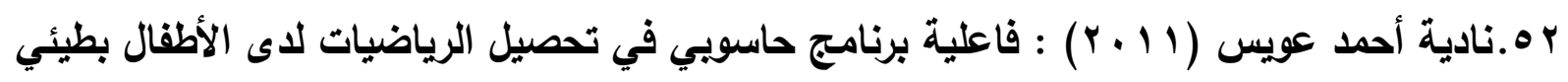

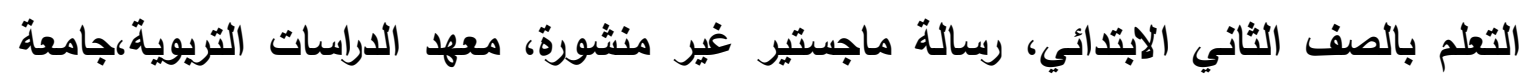
القاهرة.

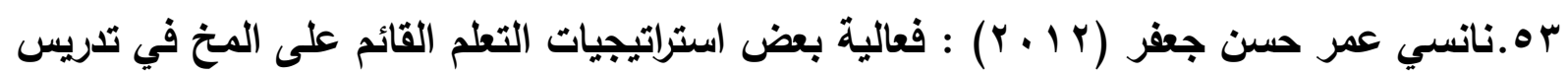

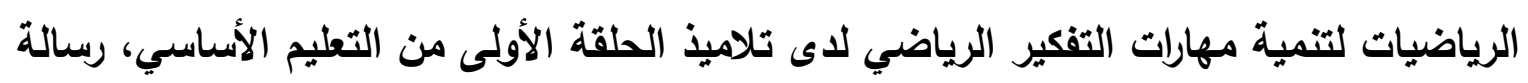

$$
\text { ماجستير غير منشورة ، كلية التربية بالعريش ، جامعة قناة السويس. }
$$

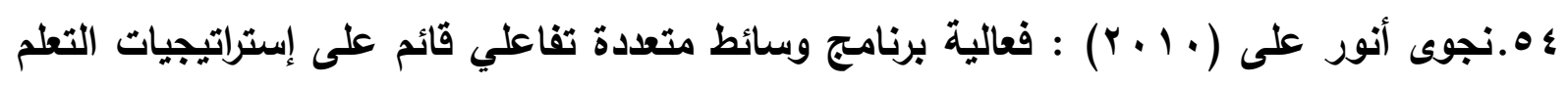

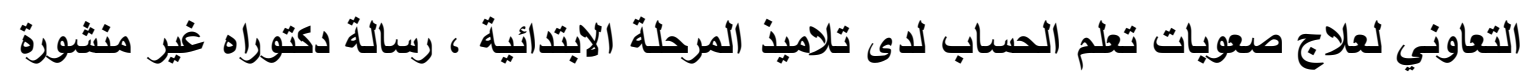

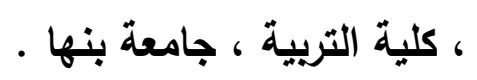




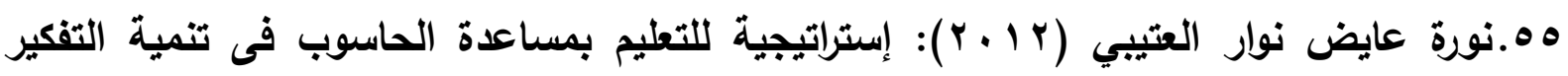
الهندسي والتحصيل لاى بطيئات التعلم بالمرحلة الابتدائية في المملكة العربية السعودية، رسالة ماجستير غير منشورة،معهد الدراسات التربوية،جامعة القاهرة.

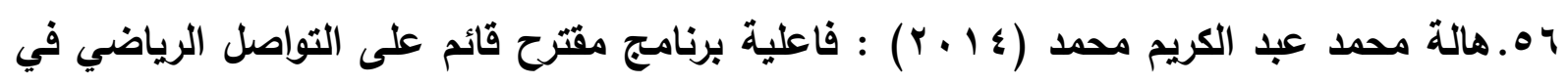
تنمية مهارات التفكير الرياضي والمهارات الحياتية لاى تلاميذ الصف الخامس الابتدائي، رسالة دكتوراة غير منشورة، معهد الاراسات التريوية، جامعة القاهرة. V. هبة عبد الحميد جمعة العيلة (Y Y r Y) : أثر برنامج مقترح قائم على أنماط التعلم لتنمية مهارات التفكير الرياضي لاعى طالبات الصف الرابع الأساسي بمحافظات غزة ، رسالة ماجستير غير منشورة ، جامعة الأزهر ، غزة .

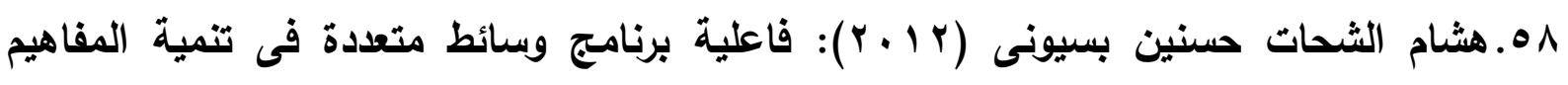
الرياضية للتلاميذ ذوى صعويات التعلم بالحلقة الأولى من التعليم الأساسي واتجاهاتهم نحو الرياضيات ، ،رسالة دكتوراه غير منشورة، معهد الدراسات التربوية ، جامعة القاهرة. 9ه. وليم عبيد (ع . r) : تعليم الرياضيات لجميع الأطفال في ضوء متطلبات المعايير وثقافة التفكير، عمان ، دار المسيرة للتشر والتوزيع.

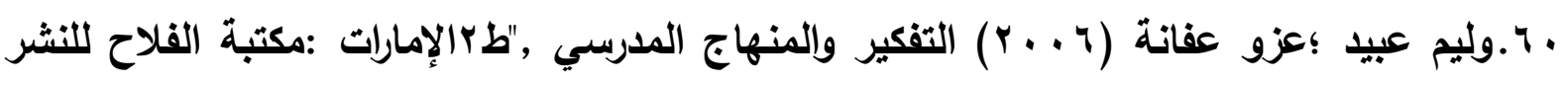
والتوزيع.

آ.وليم عبيد وآخرون (ع . . Y) : طرق تدريس الرياضيات (Y) ، برنامج تأهيل معلمي المرحلة الابتدائية للمستوى الجامعي ، القاهرة ، دار التوفيقية للطباعة .

ثانبا : المراجع الأجنبية

62. Andrado, E. L.؛ Mercado, C. A\& Reynoso, J. M. (2008). Learning Data Structure Using Multimedia .Interactive Systems, Mexico: Communications of the IIMA. , Vol.8.Issue 3, pp25-32.

63. Barbara, $\mathrm{S} \&$ Michael, A\& Dubinsky, Ed. (2009). Advanced Mathematical Thinking, Mathematical Thinking and Learning, V(7), n (1) ,15-25

64. Banet \&Nunez. (2001) .Teaching and Learning about Human Nutrition , International Journal of Science Education, V (19), N(9) , PP 169-194.

65. Behzet, B. (2006). The relationships between spatial ability, logical thinking, mathematics performance and kinematics graph interpretation skills of 12th grade physics students, Doctor of Philosophy, Ohio State University, Teaching and Learning.

66. Birgan, L. (2010). The Effects of Multimedia Technology on Students' Perceptions and Retention Rates in Mathematics at a Community 
College, Unpublished Doctor of Education Dissertation, Graduate Faculty of the School of Education, North central University .

67. Burris, J. (2010). "Third Graders' Mathematical Thinking of Place Value through the Use of Concrete and Virtual Manipulative." Unpublished Doctor of Education Dissertation, Faculty of the College of Education, University of Houston, May, 2010.

68. David, K. (2001). Algebra For all: The role of Technology and constructivism in an algebra course for At- Risk students, Preventing School Failure, V (45), N (4), and EJ (637193).

69. Delcham, H. (2005). The Effects of Interactive Mathematics Software in A Community College Remedial Class, Unpublished Doctor of Education Dissertation, Teachers College, Columbia University

70. Delgado, A. (2007). The Effects Of Multimedia Technology On The Learning OF Math Story Problems OF Elementary And Middle School Deaf Students, Unpublished Master of Education Dissertation, The Faculty of the College of Graduate Studies, Lamar University

71. Fonkert, K. (2012). Patterns of in Traction and Mathematical Thinking of High School Students IN Classroom Environments That Include use OF Java- Based, Curriculum Embedded Software, Unpublished Doctor of Education Dissertation, Faculty of The Graduate College, Western Michigan University.

72. Gallagher, K. (2010). The Impact of Learning Style on Learning Outcomes in an Interactive Multimedia Instruction (IMI) Program, Unpublished Doctor of Education Dissertation, the Faculty of the College of Education, TUI University Cypress, California.

73. Goodwin, K. (2008) .The impact of interactive multimedia on kindergarten students' representations of fractions Issues in Educational Research, 18(2), 2008.

74. Huggins, G. (2012). Evaluating The Effectiveness OF A Multimedia Tutorial System ON Computer Self- Efficacy AND Learning Outcomes OF Mathematics Students, Unpublished Doctor of Education Dissertation, The Faculty of the Graduate School, Southern University and A \& M College

75. John, G. (2001) . Education for the Slow Learners, London, Practice, Hall, Inc.

76. Leung, M. (2008). Promoting And Measuring Mathematical Thinking and Strategy use In Young Children Through Computer- Based Activities, Unpublished Doctor of Education Dissertation, Teachers College, Columbia University

77. Malik, I. (2010). Effects of Multimedia-Based Instructional Technology on African American Ninth Grade Students' Mastery of Algebra Concepts, Unpublished Doctor of Education Dissertation, University of Phoenix. 
(فاعلية برنامج قائم على النموذج البنائي التكاملي باستخدام الوسائط المتعددة الثفاعلية في تنمية التفكير الرياضي والدافعية نحو تعلم

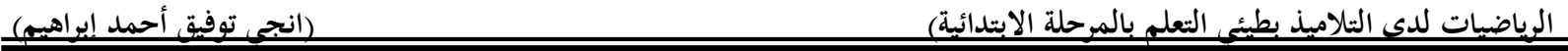

78. National council of teacher of Mathematics (NCTM) (2000). Principles and Standards of school Mathematics, The National Council of Teachers of Mathematics, Inc.

79. Pape, S., Bell, C. \& Yetkin, I. (2003). Developing Mathematical Thinking and Self-regulated Learning: A teaching experiment in a seventh grade mathematics classroom, Educational Studies in Mathematics, Vol. 53, No. 3 (2003), pp. 179-202

80. Shaw, S. (2010). Rescuing Student from the slow learner Trap, principal leadership, Feb, PP. 12 - 16.

81. Singleton, C. (2009). An Examination of Student Attitudes And Understanding of Exponential Functions using Interactive Instructional Multimedia, Unpublished Doctor of Education Dissertation, the Faculty of the Graduate School Southern University and $A$ \& $M$ College

82. Toles, A. (2010). "Effects of Teaching Strategies on Student Motivation to Learn in High School Mathematics Classes", Diss. Abs. Int. Proquest LLc, http://www.eric.ed.gov/

83. Traci, H. (2001) .Why Corporations Are using Interactive Multimedia for Sales, Marketing and Training, Available at: URL: http:// www.etimes.com $(\underline{3 / 2 / 2014})$

84. Zunker, L. (2008). Computer- Based Instruction And Mathematics Skills OF Elementary Students With Learning Disabilities, Unpublished Doctor of Education Dissertation, College of Graduate Studies Texas A\&M University-Kingsville and Texas A\&M University-Corpus Christi. 